\title{
The process of ghost-rock karstification and its role in the formation of cave systems
}

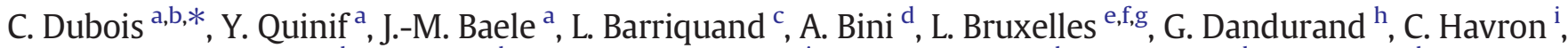 \\ O. Kaufmann ${ }^{\text {a }}$, B. Lans ${ }^{\text {h}}$, R. Maire ${ }^{\text {h }}$, J. Martin ${ }^{\text {c }}$, J. Rodet ${ }^{\mathrm{j}}$, M.D. Rowberry ${ }^{\text {k}}$, P. Tognini ${ }^{\mathrm{d}}$, A. Vergari ${ }^{1}$
}

a Department of Geology and Applied Geology, Faculty of Engineering, University of Mons, rue de Houdain 9, B-7000 Mons, Belgium

${ }^{\mathrm{b}}$ Fond National de la Recherche Scientifique (FNRS), rue d'Egmont 5, B-1000 Brussels, Belgium

c Association de Recherche Paléoécologique en Archéologie (ARPA), Department of Earth Science, University Claude Bernard, Lyon I, rue Dubois 2, F-69622 Villeurbanne, France

' Department of Earth Science, University of Milan, via Mangiagalli 34, 20133 Milan, Italy

e Institut National de Recherches Archéologiques Préventives (INRAP), rue Etienne Lenoir 561, F-30900 Nimes, France

${ }^{\mathrm{f}}$ Travaux et Recherches Archéologiques sur les Cultures, les Espaces et les Sociétés (TRACES), UMR 5608, Centre national de la recherche scientifique (CNRS), University of Toulouse le Mirail, Allée Antonio Machado 5, 31058 Toulouse, France

'School of Geography, Archaeology and Environmental Studies (GAES), University of the Witwatersrand, Jan Smuts Avenue 1, 2000 Johannesburg, South Africa

h Laboratoire de l'Aménagement, Développement, Environnement, Santé et Sociétés (ADES), UMR 5185, Centre national de la recherche scientifique (CNRS), University of Bordeaux III,

Esplanade des Antilles 12, 33607 Pessac, France

i Institut Interuniversitaire des Silicates, Sols et Matériaux (INISMa), Avenue Gouverneur Cornez 4, B-7000 Mons, Belgium

${ }^{\mathrm{j}}$ Laboratory of Continental and Coastal Morphodynamics, UMR 6143, Centre national de la recherche scientifique (CNRS), University of Rouen, Place Emile Blondel,

76821 Mont Saint Aignan, France

${ }^{\mathrm{k}}$ Department of Engineering Geology, Institute of Rock Structure and Mechanics, Academy of Sciences of the Czech Republic, V Holešovičkách 41,18209 Prague 8, Czech Republic

${ }^{1}$ SAGREX, Heidelberg Cement Group, Chaussée de la Hulpe 185, B-1170 Bruxelles, Belgium

\section{A R T I C L E I N F O}

\section{Article history:}

Received 3 July 2013

Accepted 21 January 2014

Available online 5 February 2014

\section{Keywords:}

Karstification

Limestone dissolution

Chemical weathering

Ghost-rock

Speleogenesis

Western Europe

\begin{abstract}
A B S T R A C T
This paper presents an extensive review of the process of ghost-rock karstification and highlights its role in the formation of cave systems. The process integrates chemical weathering and mechanical erosion and extends a number of existing theories pertaining to continental landscape development. It is a two stage process that differs in many respects from the traditional single-stage process of karstification by total removal. The first stage is characterised by chemical dissolution and removal of the soluble species. It requires low hydrodynamic energy and creates a ghost-rock feature filled with residual alterite. The second stage is characterised by mechanical erosion of the undissolved particles. It requires high hydrodynamic energy and it is only then that open galleries are created. The transition from the first stage to the second is driven by the amount of energy within the thermodynamic system. The process is illustrated by detailed field observations and the results of the laboratory analyses of samples taken from the karstotype area around Soignies in southern Belgium. Thereafter, a series of case studies provide a synthesis of field observations and laboratory analyses from across western Europe. These studies come from geologically distinct parts of Belgium, France, Italy, and the United Kingdom. The process of ghost-rock karstification challenges a number of axioms associated with the process of karstification by total removal. On the basis of the evidence presented it is argued that it is no longer acceptable to use karst morphologies as a basis with which to infer specific karstogenetic processes and it is no longer necessary for a karst system to relate to base level as ghost-rock karstification proceeds along transmissive pathways in the rock. There is also some evidence to suggest that ghost-rock karstification may be superseded by karstification by total removal, and vice versa, according to the amount of energy within the thermodynamic system. The proposed chemical weathering and subsequent mechanical erosion of limestone suggest that the development of karst terrain is related far more closely to the geomorphological development of aluminosilicate and siliceous terrains than is generally supposed. It is now necessary to reconsider the origin of many karst systems in light of the outlined process of ghost-rock karstification.
\end{abstract}

(c) 2014 Elsevier B.V. All rights reserved.

\footnotetext{
* Corresponding author at: Department of Geology and Applied Geology, Faculty of Engineering, University of Mons, 9 rue de Houdain, 7000 Mons, Belgium. Tel.: + 32 65374613; fax: +3265374610 .

E-mail addresses: caroline.dubois@umons.ac.be (C. Dubois), yves.quinif@umons.be (Y. Quinif), jean-marc.baele@umons.ac.be (J.-M. Baele), lionel.barriquand@wanadoo.fr

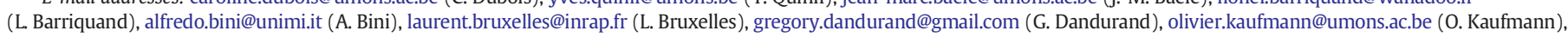
b.lans@ades.cnrs.fr (B. Lans), rmaire@ades.cnrs.fr (R. Maire), joel.rodet@univ-rouen.fr (J. Rodet), rowberry@irsm.cas.cz (M.D. Rowberry).
} 
Contents

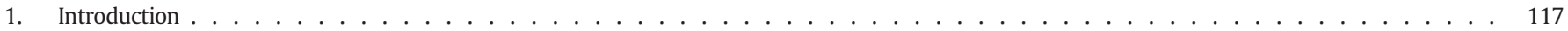

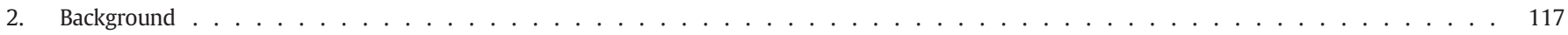

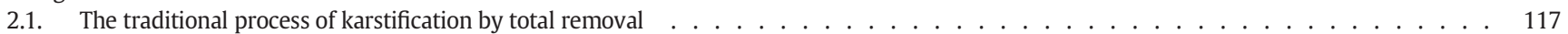

2.1.1. Two simultaneous stages: chemical dissolution and mechanical erosion . . . . . . . . . . . . . . . . . . 118

2.1.2. The thermodynamic regime . . . . . . . . . . . . . . . . . . . . . . . . . . 119

2.1.3. The structure and feature geometry of the karst network . . . . . . . . . . . . . . . . . . . 119

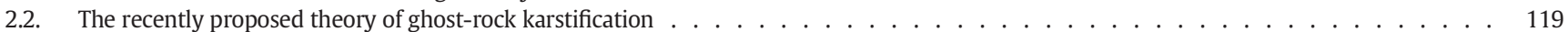

2.2.1. The process of ghost-rock karstification . . . . . . . . . . . . . . . . . . . . . . . . . . . . . . . . . 120

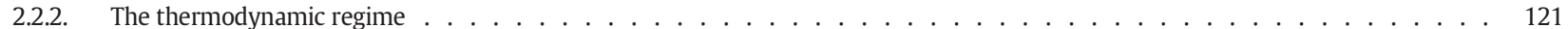

2.2.3. The structure and feature geometry of the karst network . . . . . . . . . . . . . . . . . . . . . . . 121

3. The karstotype for ghost-rock karstification: Soignies, southern Belgium ～. . . . . . . . . . . . . . . . . . . . . . . . . . 222

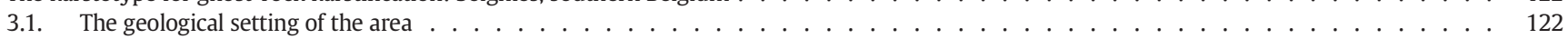

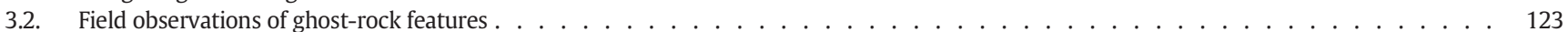

3.3. Analytical investigations of the alterite . . . . . . . . . . . . . . . . . . . . . . . . . . . . 124

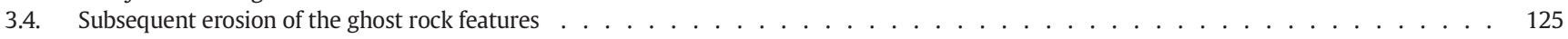

3.5. A summary of the results in terms of ghost-rock karstification . . . . . . . . . . . . . . . . . . . . . . . . . . . 126

4. Ghost-rock karstification in other geological settings . . . . . . . . . . . . . . . . . . . . . . . . . 126

4.1. Belgium . . . . . . . . . . . . . . . . . . . . . . . . . . . . . . 127

4.1.1. The Tournaisian siliceous limestone of Tournai . . . . . . . . . . . . . . . . . . . . . . . . . . 127

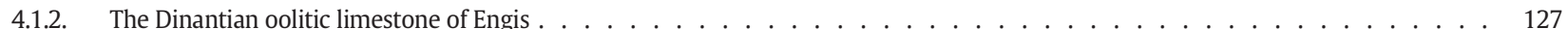

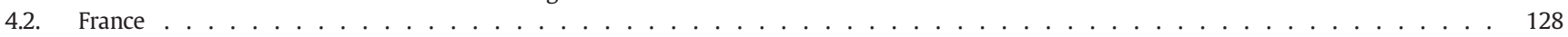

4.2.1. The Rupelian bioclastic limestone of Aquitaine . . . . . . . . . . . . . . . . . . . . . . . . . . . . . . . 128

4.2.2. The Mid-Jurassic limestone of Burgundy . . . . . . . . . . . . . . . . . . . . . . . . . . . . . . . . . . . . 130

4.2.3. The Kimmeridgian oolitic limestone of Charente . . . . . . . . . . . . . . . . . . . . . . . . . . . . 132

4.2.4. The Jurassic limestone and dolomite of Les Grands Causses ～. . . . . . . . . . . . . . . . . . . . . . . . . . . . . . 135

4.2.5. The Cenomanian chalky limestone of Normandy . . . . . . . . . . . . . . . . . . . . . . . . . 137

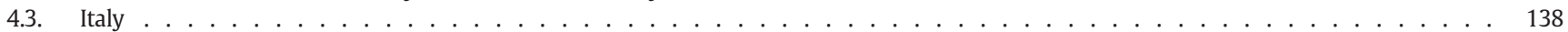

4.3.1. The Liassic silico-clay limestone of Lombardy . . . . . . . . . . . . . . . . . . . . . . . . . . . . 138

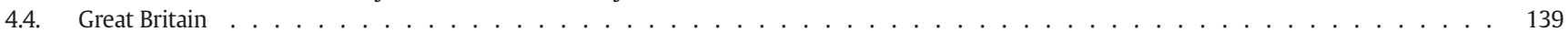

4.4.1. The Carboniferous limestone of southern Pembrokeshire . . . . . . . . . . . . . . . . . . . . . . . . 139

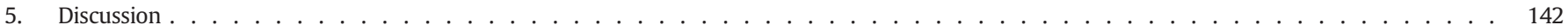

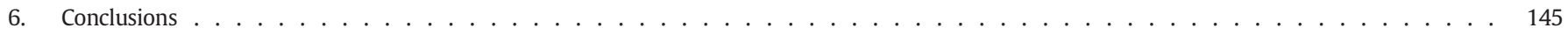

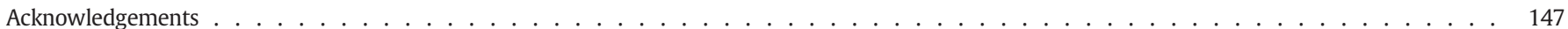

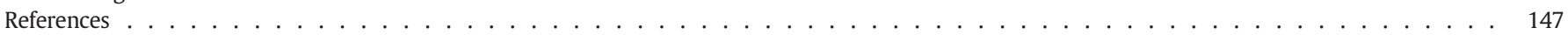

\section{Introduction}

This manuscript presents the first comprehensive review of the process of ghost-rock karstification and highlights its role in the formation of cave systems. It is a process that has been investigated intensively by researchers from the Francophone karstological community since the mid-1990s. However, as most of the studies have been published in French, this review also enables the process of ghost-rock karstification to be presented to the wider karstological and geological communities for the first time. The process of ghost-rock karstification offers an alternative to the traditional paradigm that exists within karstological research, that of karstification by total removal, by separating chemical dissolution and mechanical erosion into two very distinct stages. It has long been known that chemical weathering of crystalline rocks leaves the less soluble materials - this process is commonly recognised at or near the surface to form, for example, sandy regoliths or lateritic soils (Bisdom, 1967; Meunier, 1977). This paper aims to demonstrate that the same fundamental process also occurs in karst regions and that this process may extend to great depths.

It is well known that dissolution phenomena occur when calcium carbonate comes into contact with water catalysed acid (Bögli, 1964; Caro, 1965; Roques, 1967; Thraikill, 1968; Bakalowicz, 1975; Morse, 1983; Dreybrodt, 1987). Moreover, any type of acid can enhance the rate of chemical dissolution, and this may come from the surface (e.g. soil and air), from depth (e.g. hydrothermal), or from within the rock itself (e.g. bacterial oxidation). The in situ weathering of limestone produces a residual material called alterite and this process is called ghost-rock karstification due to the fact the rock retains the same physical appearance despite having been greatly altered. Ghost-rock features have been found in limestone (Schmidt, 1974; Martini, 1985; Quinif et al., 1993), dolomite (Bini, 2002; Bruxelles, 2002a,b) and chalk
(Rodet, 1996). There was no direct evidence to link ghost-rock karstification to the formation of cave systems until ten years ago despite strong observational support (Rodet, 1999; Bruxelles, 2001; Bruxelles and Bruxelles, 2002; Rodet, 2002, 2003, 2004; Quinif et al., 2006). It was finally demonstrated experimentally following the discovery of Quentin Cave in southern Belgium (Quinif and Maire, 2007; Quinif et al., 2014).

The first part of this manuscript describes the processes of karstification by total removal and ghost-rock karstification then, for each, outlines their thermodynamic regime and their structure and feature geometry. The second part details the ghost-rock features and analytical properties of the alterite found around Soignies in southern Belgium. The third part illustrates the process of ghost-rock karstification in geologically distinct parts of western Europe: Belgium (the siliceous limestone of Tournai and the oolitic limestone of Engis); France (the bioclastic limestone of Aquitaine; the limestone of Burgundy; the oolitic limestone of Charente; the dolomite of Les Grand Causses; and the chalky limestone of Normandy); Italy (the silico-clay limestone of Lombardy); and the United Kingdom (the argillaceous limestone of Pembrokeshire). The manuscript concludes with a discussion of some of the implications of this process. It is, in particular, suggested that there are far greater similarities between the processes operating on karst and non-karst terrain than is generally appreciated.

\section{Background}

\subsection{The traditional process of karstification by total removal}

The pioneering cave explorations carried out by the father of modern speleology, Édouard-Alfred Martel (e.g. Martel, 1894, 1900, 1928), have led to the study of innumerable karst systems around the world 
(e.g. Van Den Broeck et al., 1910; Courbon and Chabert, 1986; White and Culver, 2012). The enduring paradigm in karstogenesis asserts that a karst network develops as a result of the flow of chemically aggressive waters along an open discontinuity in the bedrock. This occurs within certain hydrogeological contexts: vadose, epiphreatic, and phreatic karstification (e.g. Gründ, 1914; Davis, 1930; Swinnerton, 1932; Rhoades and Sinacori, 1941; Bretz, 1942; Bögli, 1964; Caro, 1965; Renault, 1967; Roques, 1967; Thraikill, 1968; Jennings, 1971; Herak and Stringfield, 1972; Nicod, 1972; Bakalowicz, 1975; Grillot and Guerin, 1975; Ford and Cullingford, 1976; Jakucs, 1977; Bögli, 1980; Morse, 1983; Bonacci, 1987; Dreybrodt, 1987; Lohmann, 1988; Ford and Williams, 1989; White, 1989; Palmer, 1991; Salomon, 2006; Gilli, 2011).

\subsubsection{Two simultaneous stages: chemical dissolution and mechanical} erosion

An acid-base reaction decomposes calcium carbonate into calcium and carbonate ions when acidified water comes into contact with limestone. As the source of the acid must be renewed, this reaction can only occur when there is flowing water, otherwise the solution saturates in ions and the dissolution process is inhibited. Therefore, the karst system develops along more permeable zones within the bedrock, such as along discontinuities - the soluble parts of the discontinuity walls

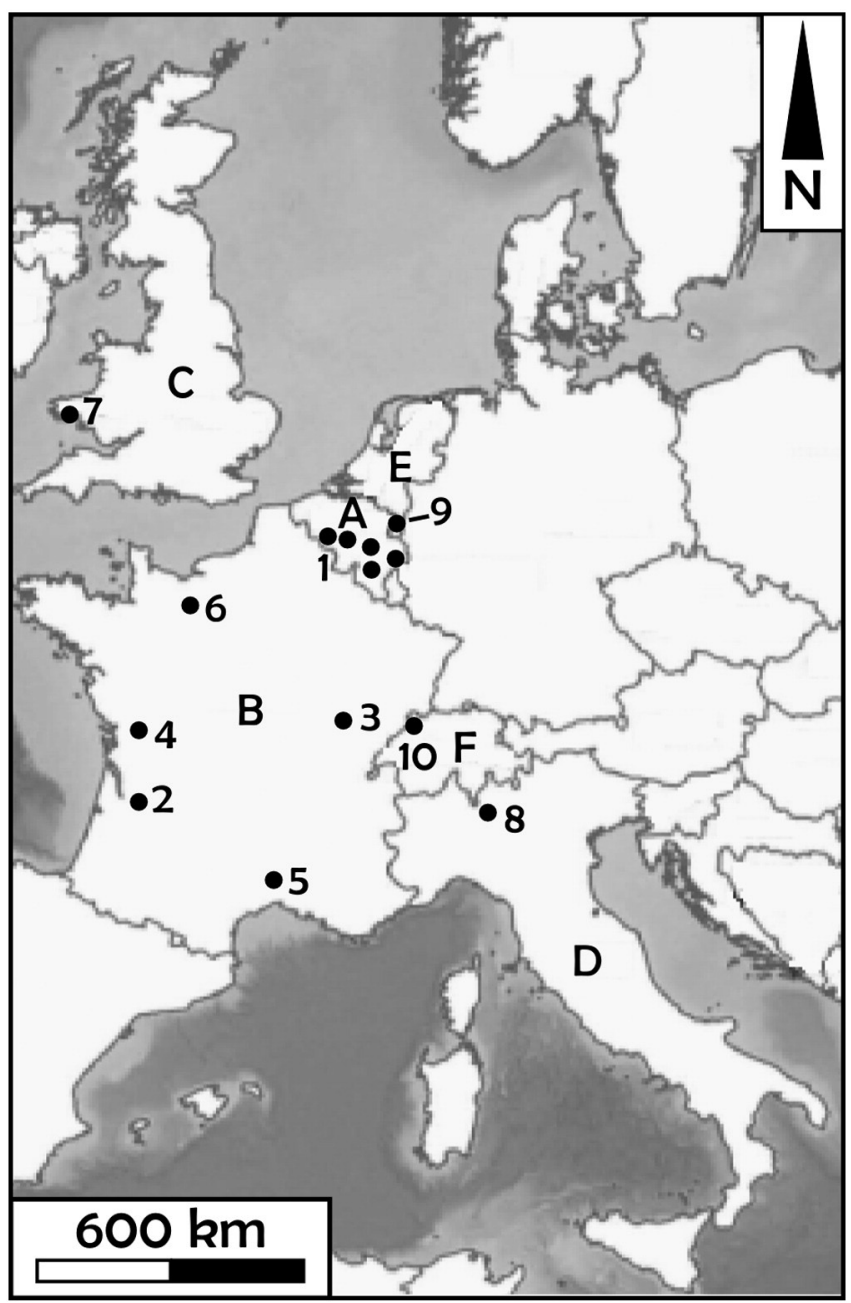

Fig. 1. The locations in which ghost-rock karstification phenomena have been studied in Europe. (A) Belgium: 1 - Wallonia; (B) France: 2 -Aquitaine; 3 - Burgundy; 4 - Charente; 5 - Languedoc; 6 - Normandy; (C) Great Britain: 7 - Pembrokeshire; (D) Italy: 8 Lombardy; (E) Netherlands: 9 - Limburg; (F) Switzerland: 10 - Canton of Bern.

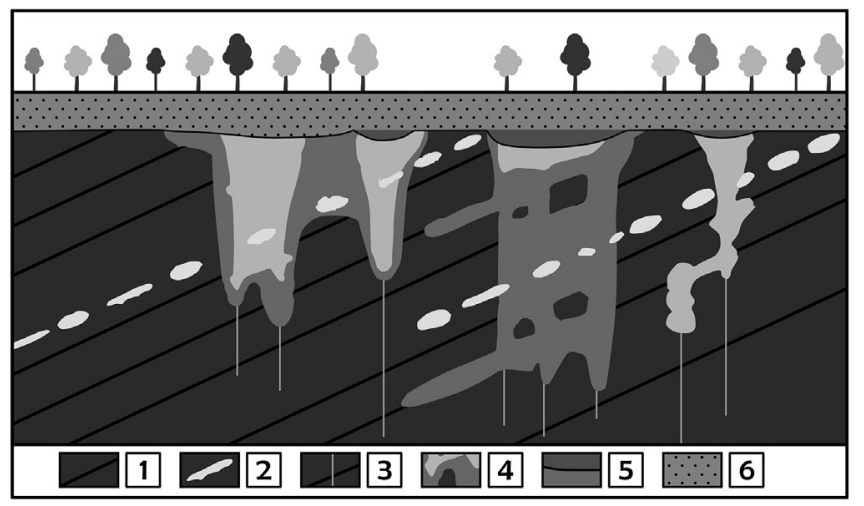

Fig. 2. A schematic diagram showing the main features of a limestone bedrock affected by the process of ghost-rock karstification (Quinif, 2010a,b): (1) limestone with bedding planes; (2) marker horizons such as chert beds, calcite veins and stylolites; (3) joints; (4) ghost-rock features containing their residual alterite - the different shades of grey represent different weathering intensities; (5-6) different types of overburden. This diagram is based on examples seen in quarries in the Tournai region of western Belgium.

are gradually dissolved during this acid-base reaction. Laboratory experiments have demonstrated that limestone dissolves progressively: dissolution begins with the micritic constituent of the carbonate before later affecting the bulkier particles such as sparitic crystals and fossils (Roques and Ek, 1973). In that experimental study, the insoluble minerals, such as clays and quartz, and the as yet undissolved particles fall to the bottom of the apparatus. During karstification by total removal, when the rock is partly dissolved, the flow of water simultaneously removes both the dissolved species and insoluble particles. This leads to the creation of an open void - no material remains as a product of the karstification phenomenon. The open void may then develop in different way according to the flow conditions: it may continue to expand, it may become filled with sediments, or it may simply become inactive. In summary, the process of karstification by total removal is characterised by: (1) chemical dissolution of the soluble

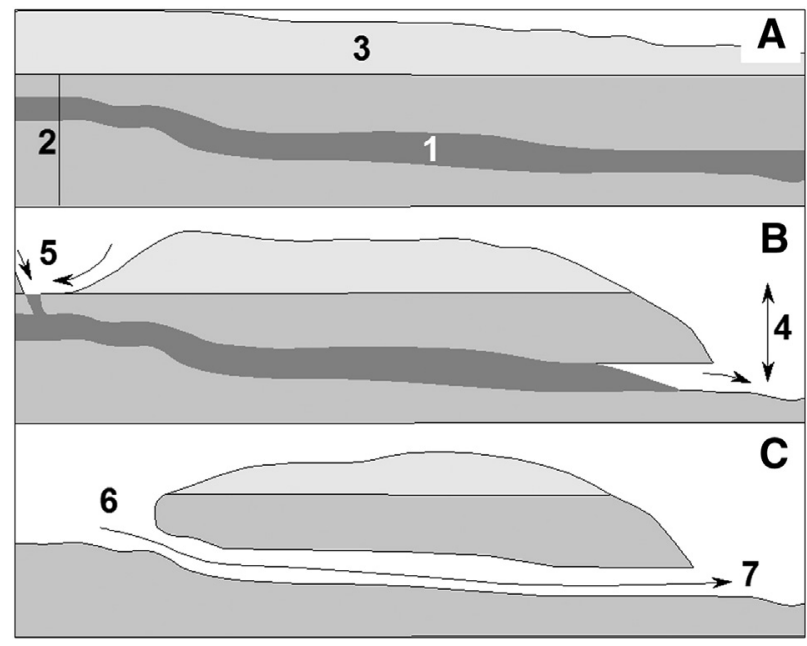

Fig. 3. The regressive mechanical erosion of a ghost-rock feature containing its residual alterite: (A) a weathered gallery (1) within a host limestone bedrock (2) sealed by an impermeable overburden (3); (B) incision into the bedrock creates relief which both increases the hydrodynamic potential of the system (4) and enables water to infiltrate into the weathered gallery (5) - this flow progressively empties the weathered gallery of its alterite from the downstream end towards the upstream end; (C) complete removal of the alterite reveals a gallery between the loss (6) and resurgence (7) of the system. This diagram is based on an example from the Entre-deux-Mers area in the Aquitaine region of southwestern France (Dubois et al., 2011). 
elements of the rock; (2) simultaneous removal of the dissolved species and mechanical erosion of the undissolved particles; and (3) the creation of open voids.

\subsubsection{The thermodynamic regime}

From a thermodynamic perspective, karst is a dissipative system (Prigogine, 1962; Glansdorff and Prigogine, 1971). The initial conditions of the system are essential as these determine whether water is able to flow through the rock. It is necessary to have open discontinuities such as bedding planes, joints, or faults in extension. The energies dissipated are chemical and hydrodynamic (Quinif, 1999). The chemical energy is obtained from the presence of an acid in the water and it enables dissolution of the rock while the hydrodynamic energy is obtained from either a potential difference in the water pathway or from hydrothermalism. The hydrodynamic energy must be sufficiently high for the water to both remove the dissolved species and to erode the undissolved particles. It has been shown that, in contrast to preconceived ideas, these energies must be dissipated simultaneously to form a karst network (Quinif, 1998). The subsequent development of galleries also relates to the energy of the water: if the stream still has high energy, it will continue to erode the rock and the gallery will widen while, conversely, if the stream has low energy, any transported particles will be deposited and the gallery will seal (Renault, 1967). Finally, if the flow stops or if the gallery is dewatered, it becomes inactive. Initially, laminar flow passes through a fractured aquifer. The first phase of karstification by total removal consists of widening the discontinuities and mechanical relaxation of the relief - this corresponds to the "protocave" phase of Ford and Williams (1989). However, as the subterranean pathway widens, the behaviour of the aquifer becomes nonlinear: Darcy's law is no longer applicable. From that moment, the aquifer becomes structured by individualising two features: the main drains, with high transmissivity but low capacity, and annex systems, with low transmissivity and high capacity (Mangin, 1975, 1982). This represents the transition from the joint lattice system to a karst network.

\subsubsection{The structure and feature geometry of the karst network}

The first factor that determines the structure of the karst network is the possibility that water is able to access to the bedrock. This geometry, therefore, depends on the interaction between the joint lattice and the tectonics stress (Quinif et al., 1997). The second factor depends on the geometric constraint as it is this that imposes the direction of water flow between the input and the output within the system - this direction is imposed by the relief. During the development of the karst system, the second factor becomes more dominant: the system is hydraulically structured (Havron et al., 2004). Therefore, under these conditions, caves systems found at several levels are commonly related to deepening piezometric levels or glacial stages (Ek, 1961; Quinif, 1989b; Audra, 1994; Jolivet and Martin, 2008). Karst networks comprise combinations of galleries, shafts, and chambers while those parts of the karst system beneath the surface are called endokarst. These galleries, shafts, and chambers may be empty or filled with fluvial sediments or concretions. A fossilised karst is a karst that is disconnected from active flow and erosional processes while a fossilised karst that has been sealed by a transgression and covered by sediments is termed a palaeokarst (Bates and Jackson, 1980; James and Choquette, 2012). Furthermore, the galleries themselves may have several types of morphologies including cupolas, overdeepings, side benches, or potholes while their walls may present different microforms such as anastomosis, channels, floots, or swage (Bretz, 1942; Renault, 1967). These networks are accessible to humans and can be explored in speleology.

\subsection{The recently proposed theory of ghost-rock karstification}

The study of weathered limestone features has intensified following their discovery in the Carboniferous limestone of southern Belgium (Quinif, 1989a; Quinif et al., 1993; Vergari and Quinif, 1997; Vergari, 1998; Kaufmann and Quinif, 1999; Kaufmann et al., 1999; Quinif, 1999; Kaufmann, 2000; Havron et al., 2007; Quinif et al., 2011, 2012; Dubois et al., 2014; Kaufmann and Deceuster, 2014; Quinif et al., 2014). These features and their associated residual alterite have now been
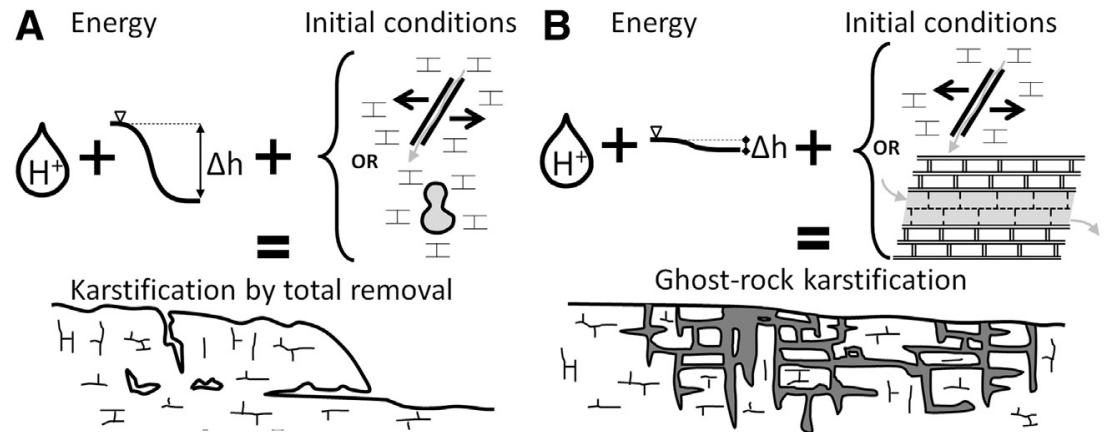

Ghost-rock karstification

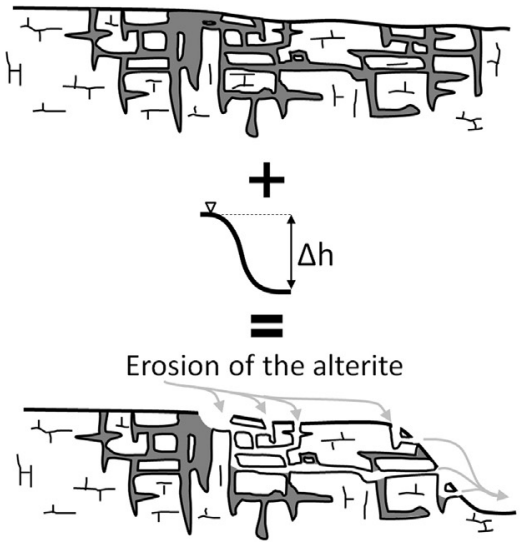

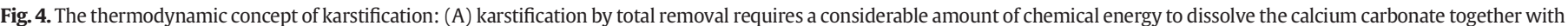

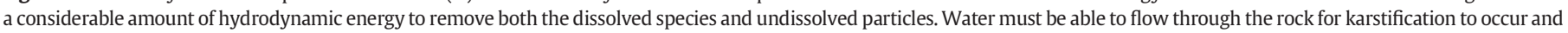

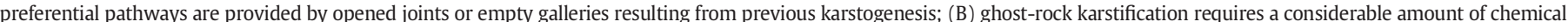

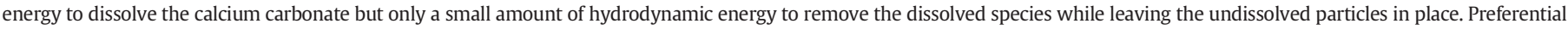

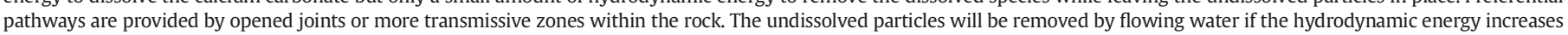
sufficiently. 
investigated in many parts of western Europe (Fig. 1): France - Alps (Audra et al., 2007), Aquitaine (Lans et al., 2006; Dubois et al., 2011; Courreges-Blanc and Maire, 2014), Burgundy (Barriquand et al., 2011a, 2012), Charente (Dandurand, 2011; Dandurand and Maire, 2011; Dandurand et al., 2014), Languedoc (Bruxelles, 2001; Bruxelles and Bruxelles, 2002; Bruxelles and Wienin, 2010), and Normandy (Rodet, 1996, 1999, 2014); Great Britain - Pembrokeshire (Rowberry et al., 2014); Italy - Alps (Audra et al., 2007), and Lombardy (Tognini, 1999a,b; Bini, 2002; Bini et al., 2012); Netherlands - Limburg (Willems et al., 2007); and Switzerland - Alps (Audra et al., 2007; Cailhol and Meury, 2012). Furthermore, instances of ghost-rock karstification are now known in South Africa (Maire et al., 2013) and Brazil (Hardt et al., 2013).

\subsubsection{The process of ghost-rock karstification}

2.2.1.1. Stage one: chemical dissolution. The process of ghost-rock karstification, as with karstification by total removal, begins with the fundamental phenomenon of calcium carbonate dissolution by acidified water. This dissolution requires a flow of water in order to renew the acid solution and, therefore, a weathering network develops from more permeable zones within the rock. The kinetics of carbonate dissolution are the same as they are for karstification by total removal: dissolution begins with the micritic constituent of the carbonate before later affecting the bulkier particles while leaving the insoluble elements intact. As the rock weathers, the seeping water removes the dissolved species but, unlike the process of karstification by total removal, the undissolved materials are not eroded simultaneously - they remain in place within the rock matrix. Therefore, during this stage of ghost-rock karstification, no open voids form but instead the ghostrock features contain a residual material termed 'alterite' (Fig. 2) (cf. Section 3.2).

2.2.1.2. Intermediate stage: vadose evolution. For as long as the ghost-rock feature remains below the piezometric surface, the water present in the alterite applies an interstitial pore pressure on the particles of the material and, therefore, the structure of the alterite is preserved in its original state. However, if the groundwater level drops below the ghost-rock feature, the interstitial water drains away from the alterite and causes its collapse due to the effect of gravity - the ghost-rock feature is settled and a macroscopic void appears at the top of the ghost-rock feature. This occurs when the piezometric level is deepening (cf. Section 4.1.1 Tournai, Belgium) or when there is a fluctuating piezometric level (cf. Section 4.2.3 - Charente, France). In contrast, if the ghost-rock feature is close to the ground surface, it immediately swallows the overburden and generates a doline or a collapse sinkhole. Moreover, if the ghostrock feature is fully encapsulated within bedrock, compaction of the alterite may weaken the rock at the top of the feature and this is able to cause the roof to collapse (Dandurand, 2011).

2.2.1.3. Stage two: mechanical erosion. During the subsequent geological evolution of area the alterite is emptied from the ghost-rock feature by

\section{A}
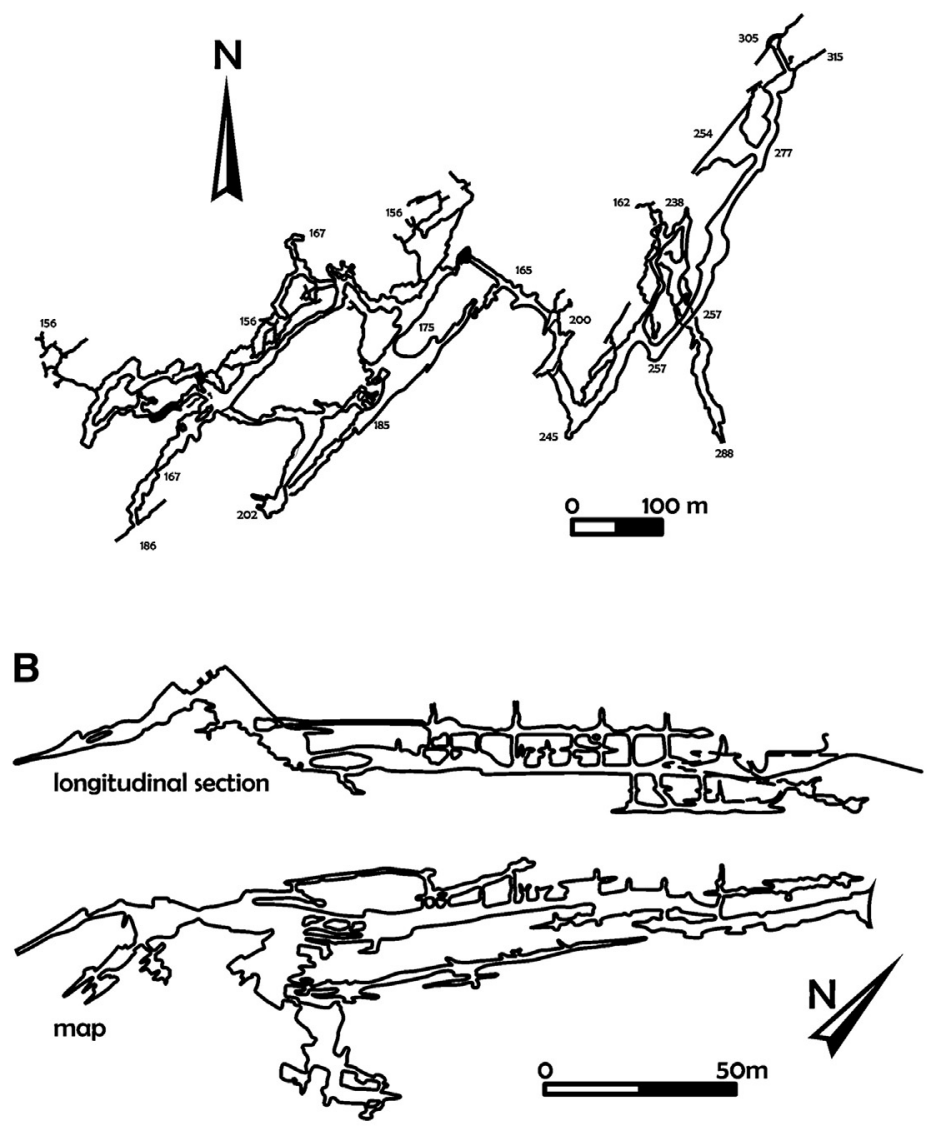

C

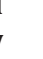




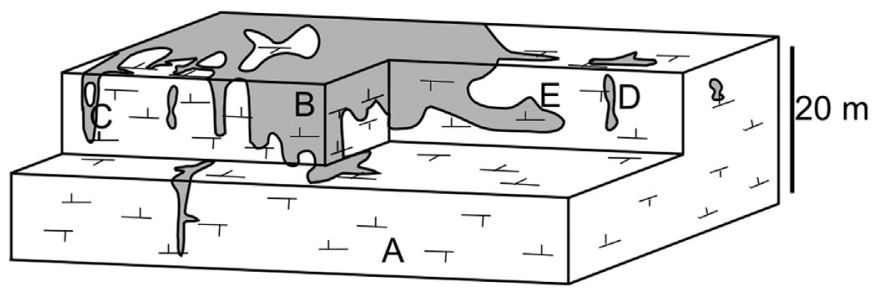

Fig. 6. A schematic diagram showing typical ghost-rock features: (A) fresh unweathered limestone; (B) large weathered features; (C) weathered corridors; (D) ghost-endokarst; (E) weathered galleries.

Modified from Kaufmann (2000).

regressive mechanical erosion (Fig. 3) (cf. Section 4.2.1 - Aquitaine, France). Upon completion the new void has the same form as a classical gallery. It may then continue to develop in one of the various ways outlined for karstification by total removal: it may continue to expand, it may become filled with sediments, or it may simply become inactive (cf. Section 4.2.2 - Burgundy, France and Section 4.3.1 - Lombardy, Italy). In summary, the process of ghost-rock karstification is characterised by: (1) chemical dissolution of the soluble elements of the rock; (2) removal of the dissolved species; and (3) creation of a weathered feature filled with the remaining alterite. Subsequently, when the appropriate conditions are met, there may be (4) mechanical erosion of the undissolved particles and (5) the creation of an open gallery.

\subsubsection{The thermodynamic regime}

From a thermodynamic perspective, it is possible to differentiate between karstification by total removal and ghost-rock karstification due to the prevailing environmental conditions (Quinif, 1998, 2010a). As with karstification by total removal, the ghost-rock karst system may be considered as a thermodynamic system with initial conditions which then exchanges energy and matter with the outside world (Fig. 4). The initial conditions of the system are the same - they enable water to flow through the rock via permeable pathways such as bedding planes, joints, faults in extension, and also porous heterogeneities within the rock. For ghost-rock karstification to occur there needs to be chemical energy to convert the bedrock into a dissolved phase (ions such as $\mathrm{Ca}^{2+}, \mathrm{HCO}_{3}^{-}$) and a non-dissolved phase (sparitic calcite, clay minerals, fossils, insoluble minerals) and enough hydrodynamic energy to ensure the circulation of fluids within the system. However, the hydrodynamic energy must be very weak to ensure that there is no mechanical erosion of the residual alterite. It is only during later geological evolution, when there is sufficient hydrodynamic energy, that there can be mechanical erosion of the undissolved particles and the creation of an open karst gallery. Therefore, to initiate the process of karstification, it is no longer necessary to invoke the "protocave" phase of Ford (Ford and Williams, 1989). The link between the input and the output of the system is ensured by the matrix porosity and discontinuities within the rock. In ghost-rock karstification, as water flows through the porous matrix of the alterite, the flow remains laminar and Darcy's law is applicable. A ghost-rock karst system can also be thought of as a system comprising main drains (well-connected zones in which the alterite presents high permeability) and annex systems (more isolated zones of alterite).

\subsubsection{The structure and feature geometry of the karst network}

The structure of karst network created by ghost-rock karstification is dictated by the initial flow pathways within the rock. The geometry may depend on the combination of the joint lattice and the tectonic stresses, as with karst networks created by total removal, or on the distribution of highly permeable zones within the rock. However, the direction between the input and output of the water in the system does not affect the weathering. Therefore, many emptied ghost-rock systems present a labyrinthine-type network (Fig. 5) with dead-end galleries and no hierarchy to the network organisation (Bruxelles and Bruxelles, 2002). Moreover, as the weathering propagates through highly permeable hydraulic pathways, the network may be spread over a number of different levels and the emptied caves from such networks bare no relation to the water table or with glacial phases (cf. Section 3.1.1 - Lombardy, Italy). The isovolumetric material is an alterite defined as "a weathering product with slight or no change in rock volume and remnant rock structure" (Delvigne, 1998). This material, comprising the less soluble elements of the rock, is very different from its parent. The weathering affects the rock matrix in several ways: as the calcium carbonate is dissolved there is a change in the overall composition of the material and its structure, while removal of the dissolved species creates a secondary porosity within the matrix, altering the hydrological properties of the rock and weakening. However, the alterite keeps the original structure of the bedrock and insoluble elements remain distinguishable (e.g. fossils, chert, calcite veining). The ghost-rock karst network may ramify through the bedrock (Fig. 6).

A nomenclature of ghost-rock features can be established to highlight their characteristic geometries: (1) wide weathered areas: these are situated beneath the overburden and they are often affected by compaction due to their dimensions which draws down the overlying cover (Fig. 7A); (2) weathered corridors: these are vertical pipes which are here seen to cross the quarry for several tens of metres (Fig. 7B); (3) weathered galleries: these are longitudinal branches of the weathering network with no apparent connection to the surface; and (4) ghost-endokarst: these are cross-sectional branches of the weathering network with no apparent connection to the surface

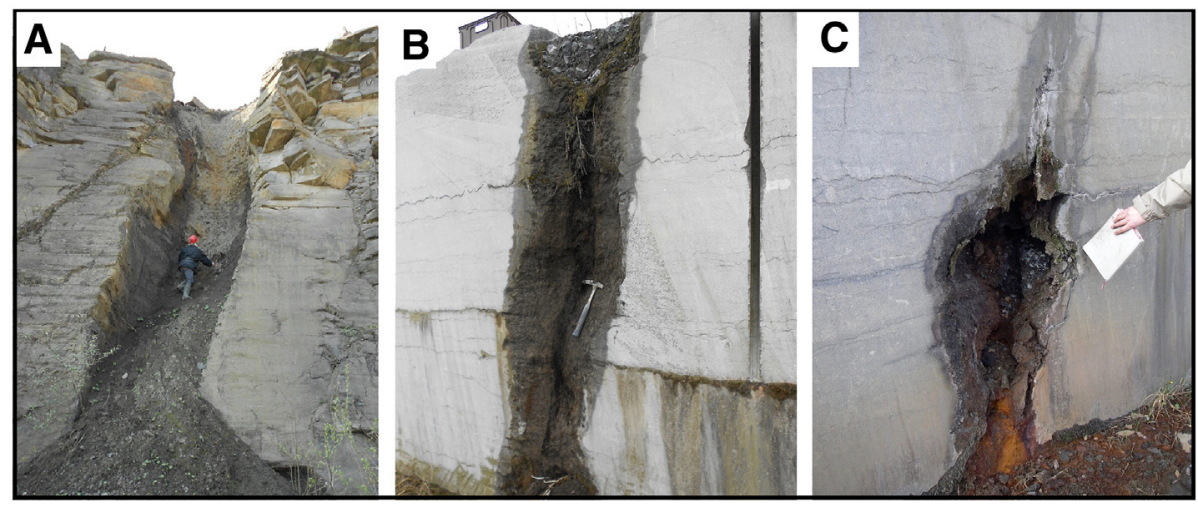

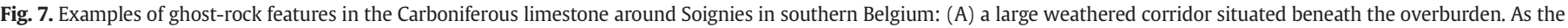

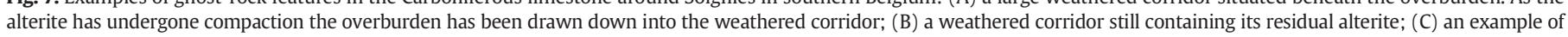
a ghost-endokarst. 

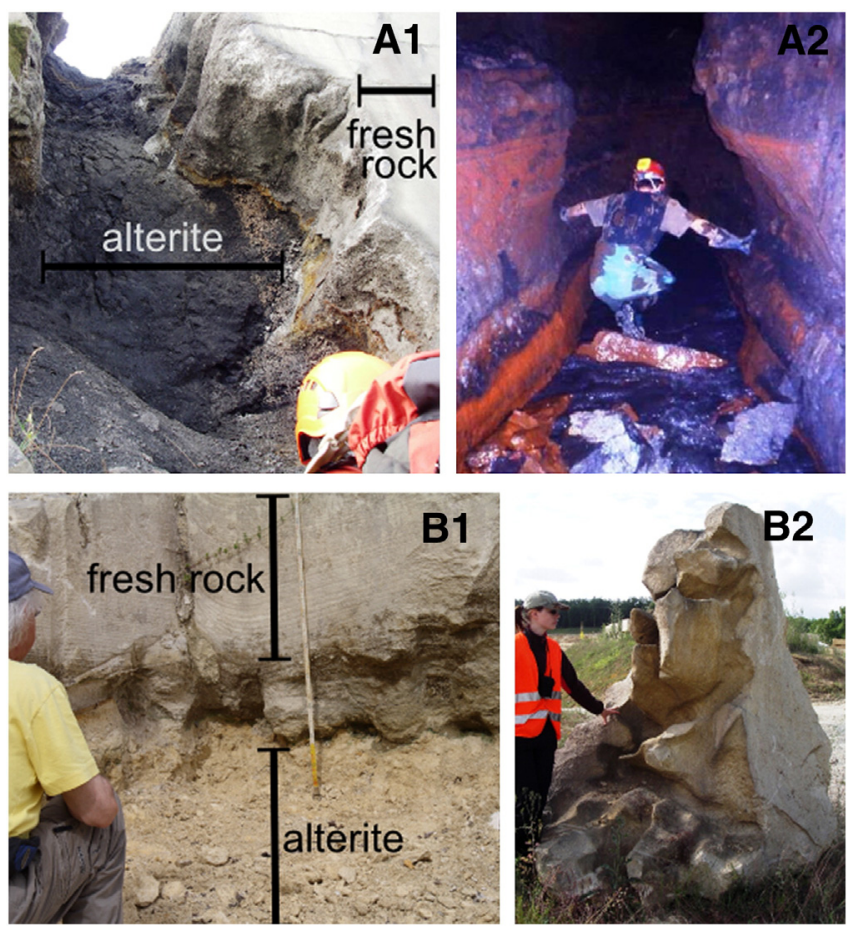

Fig. 8. Examples of parietal morphologies resulting from ghost-rock karstification around Soignies in southern Belgium (A) and Aquitaine in southwestern France (B) (Dubois et al., 2011): (A1) a weathered corridor containing its residual alterite presents cupolas on its walls; (A2) a weathered gallery with cupolas seen after removal of the alterite; (B1) a ghost-rock feature containing its residual alterite presents vault anastomoses; (B2) vault anastomoses resulting from ghost-rock karstification seen after removal of the alterite.

(Fig. 7C). These features are all filled with alterite and can be seen to preserve the overall structure of the parent rock. A fossilised ghost-rock feature sealed by sediments, is designated a ghost-palaeokarst, following the terminology of Bates and Jackson (1980). It is important to note that some morphologies that have commonly been related to karstification by total removal, such as cupolas and anastomosis, are also found in ghost-rock features still containing their alterite (Fig. 8). It is possible to observe ghost-rock features in quarries where the bedrock is exposed but their passages can only be explored by speleologists once they have been emptied. However, once emptied of their alterite,
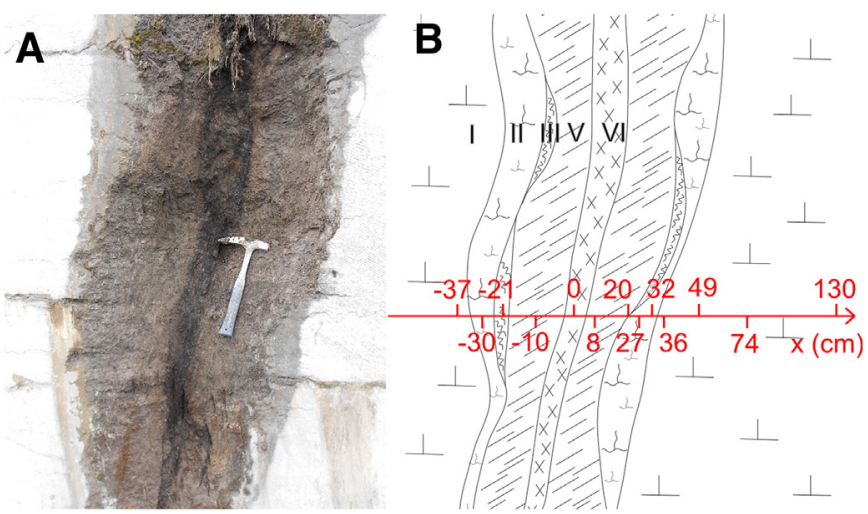

Fig. 10. (A) A weathered zone selected for sampling in the Petit Granit at Clypot Quarry in Neufvilles. (B) A sketch of the weathered zone - the samples were taken in stratigraphic continuity and they are identified by their distance, in $\mathrm{cm}$, from the centre of the weathering (Dubois et al., 2014). The zone comprises five distinct constituents as defined by the standard terminology of Price (2009): I - fresh rock with no recognisable signs of weathering; II - slightly weathered rock with slight changes in colour and slight weakening; III - moderately weathered rock with conspicuous changes in colour and noticeable weakening but which cannot yet be broken by hand; V - completely weathered rock with its original texture still apparent but considerably weakened and which disintegrates in water (= alterite); VI - residual soil derived from in situ weathering which has lost the original texture and fabric of the fresh rock. It should be noted that Grade IV, highly weathered rock, is not present in this weathered feature.

the ghost-rock features will develop as classical galleries and present the same profiles.

\section{The karstotype for ghost-rock karstification: Soignies, southern Belgium}

\subsection{The geological setting of the area}

The karstotype defines the area in which a specific karst feature or process is most representative and, for ghost-rock karstification, this area is found around Soignies in southern Belgium (Doremus and Hennebert, 1995). It is recognised in the Carboniferous bedrock and it appears that the Upper Tournaisian limestones are particularly susceptible to this karstification process. These are very compact pure fossiliferous limestones with low bulk porosity and a dark blue-grey colour. The Palaeozoic strata in hereabouts have a monoclinal structure

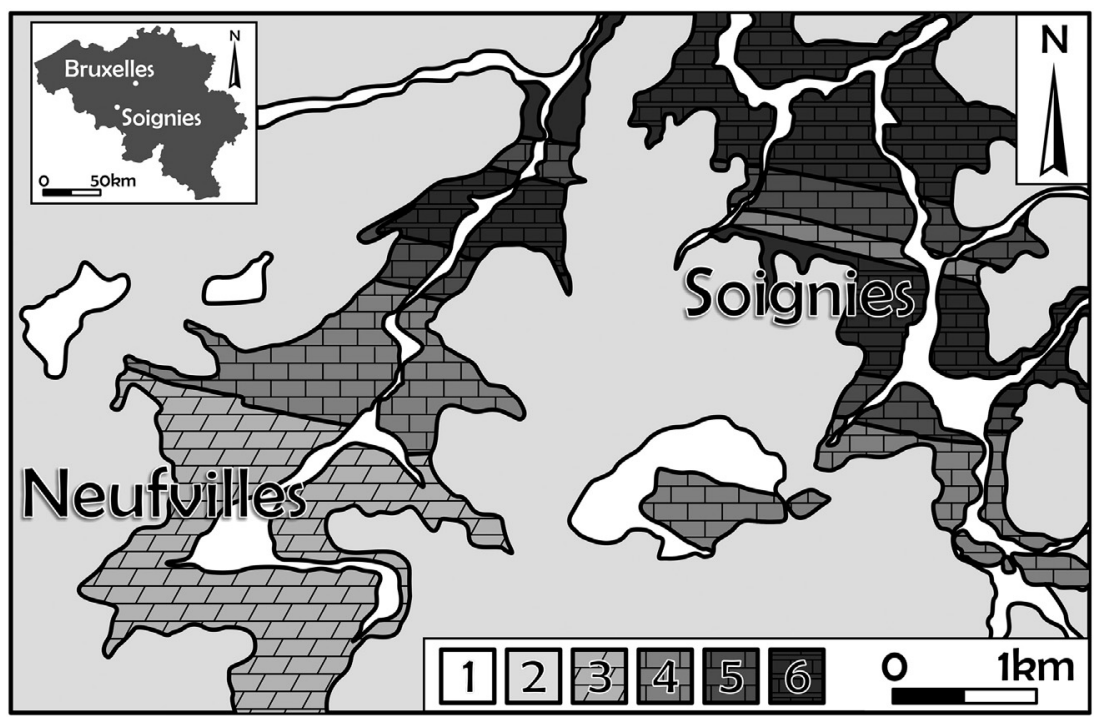

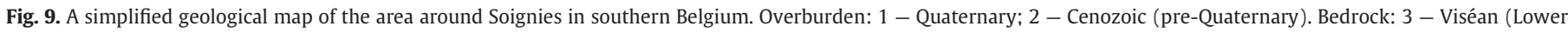
Carboniferous); 4 - Upper Tournaisian (Lower Carboniferous); 5 - Lower Tournaisian (Lower Carboniferous); 6 - Upper Devonian. Modified from Doremus and Hennebert (1995). 

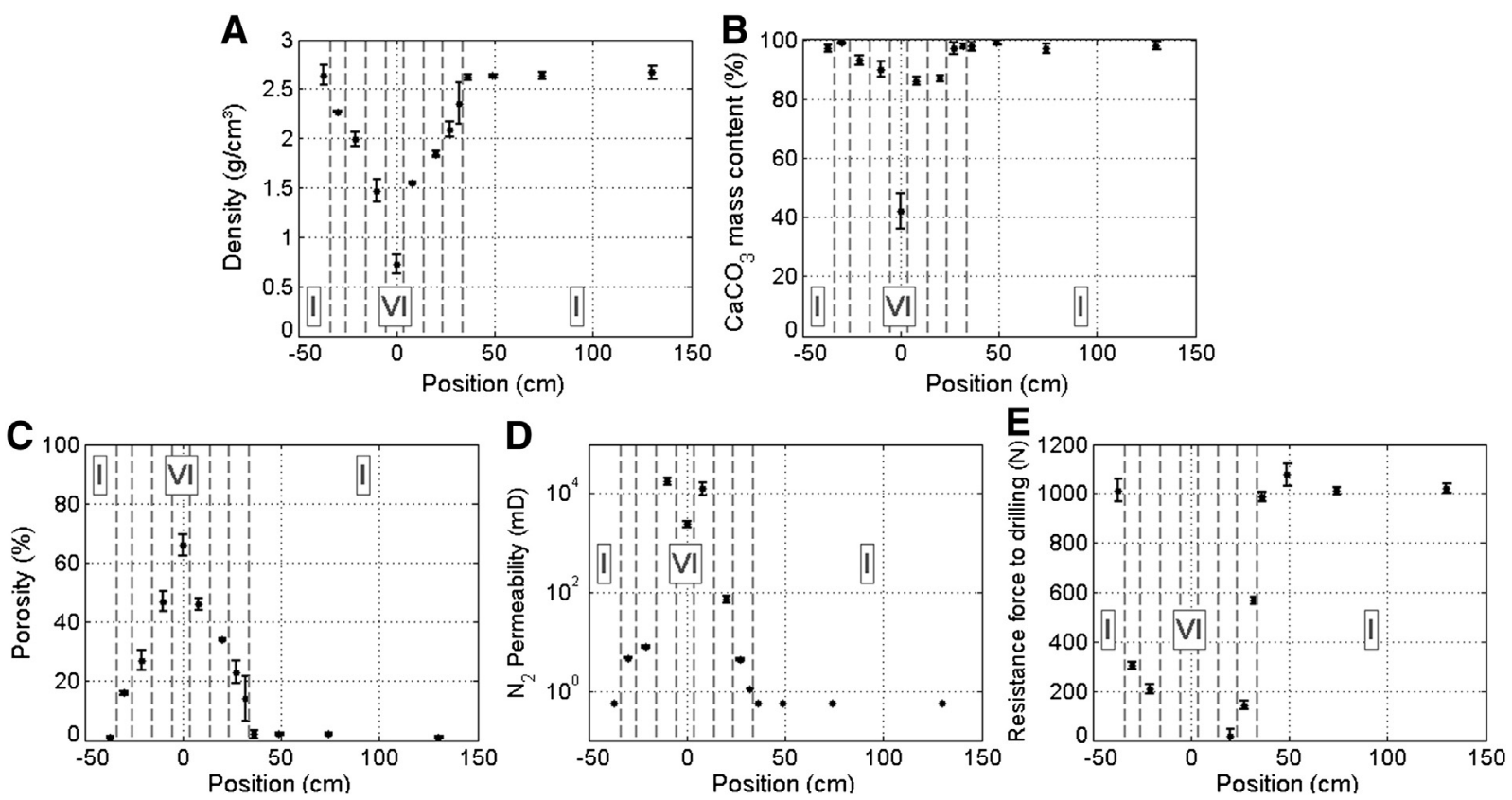

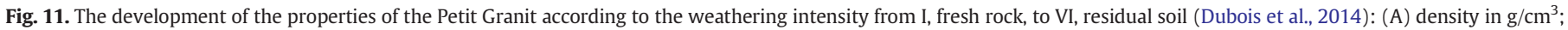
(B) $\mathrm{CaCO}_{3}$ mass content; (C) porosity in \%; (D) nitrogen permeability in $\mathrm{mD}$; (E) resistance force to drilling in $\mathrm{N}$.

oriented North $100^{\circ}$ and dipping $12^{\circ}$ to the South (Fig. 9). Individual beds are from $0.7 \mathrm{~m}$ to $2 \mathrm{~m}$ thick while the total thickness of the unit in this area is about $125 \mathrm{~m}$. The strata are unconformably overlain by Cenozoic overburden. These units are affected by intensive fracturing that follows three main directions: $\mathrm{N} 60^{\circ} \mathrm{E}, \mathrm{N} 100^{\circ} \mathrm{E}$, and $\mathrm{N} 120^{\circ} \mathrm{E}$ (Quinif et al., 1997). Due to its quality, a large number of quarries around Soignies continue to exploit the limestone as an ornamental stone, and these quarries represent exceptional places in which to observe karst phenomena.

\subsection{Field observations of ghost-rock features}

In this area it is possible to study ghost-rock features as soon as they appear in fresh quarry faces (Quinif et al., 2006; Havron et al., 2007;
Quinif, 2010a; Quinif and Maire, 2010; Quinif et al., 2012, 2014; Dubois et al., 2014). The ghost-rock features spread vertically along the permeable pathways such as joints and fractures in the bedrock. It is common for joints, in particular, to be affected by the weathering process and it is possible to see numerous weathered corridors beneath the overburden and ghost-endokarsts at several tens of metres below the surface (Fig. 7). The weathered corridors and ghost-endokarsts may have widths from centimetres to decametres and they can deepen to several tens of metres. These features are often highly concentrated and, due to the fact that the weathering affects each of the three different joint systems, they coalesce to form a three-dimensional maze. However, in this region, perhaps the most important observations regarding the process of ghost-rock karstification have been made at Nocarcentre Quarry and Gauthier-Wincqz Quarry.
130

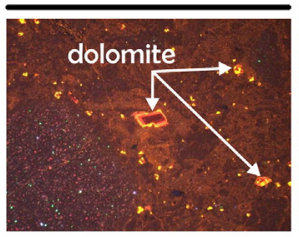

20

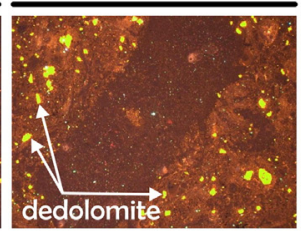

08

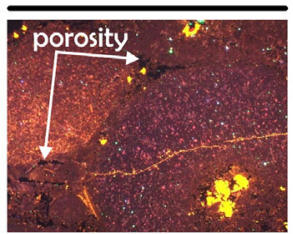

04

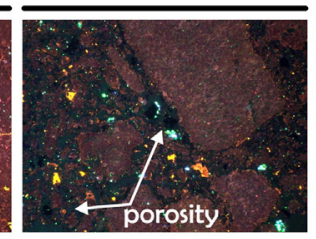

\section{Weathering intensity}

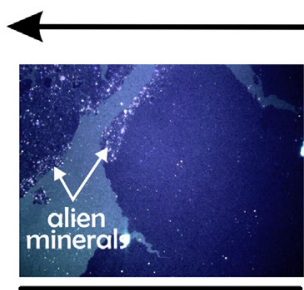

00
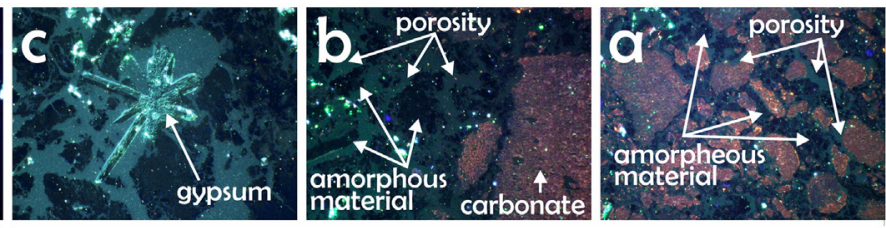

02

$500 \mu \mathrm{m}$

Fig. 12. Thin-sections of the Carboniferous limestone Petit Granit in various stages of weathering under cathodoluminescence. The number of the thin-section refers to the position of the sample, in $\mathrm{cm}$, relative to the centre of the weathered feature: (\#130) - fresh unweathered rock; (\#20) - moderately weathered rock; (\#08) to (\#02) - completely weathered rock; $(\# 02)$ to $(\# 00)$ - residual soil. The transition from Grade V to Grade VI is clear in thin-section (\#02). It is possible to see, for example, a notable change in the composition and texture of the alterite in (\#02b). 


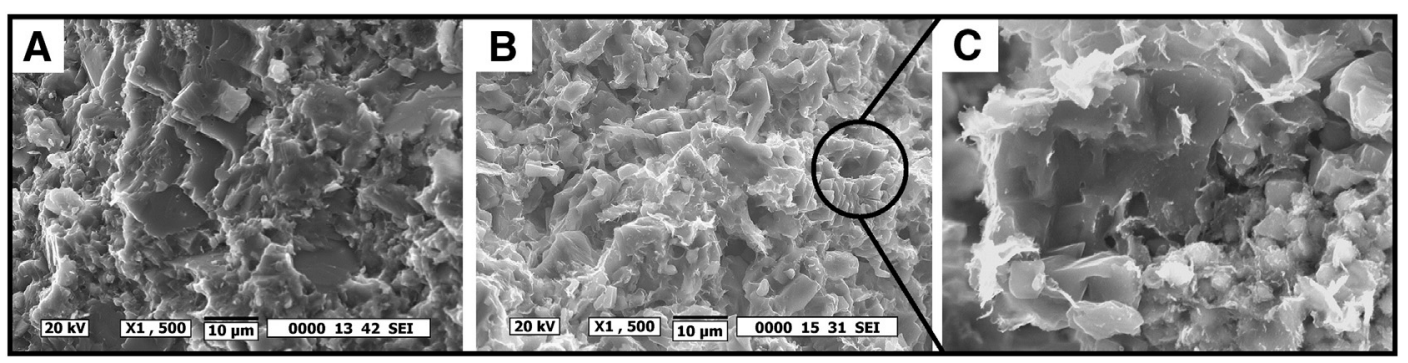

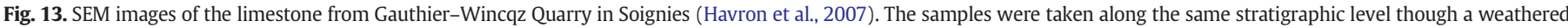

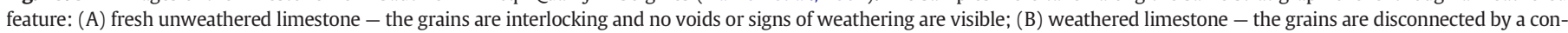
tinuous pore network; (C) detail of a weathered sparitic crystal affected by corrosion gulfs.

\subsection{Analytical investigations of the alterite}

The weathered alterite from Clypot Quarry has been subjected to mineralogical and petrophysical analyses in order to understand the development of the alterite properties during the weathering process (Dubois et al., 2014). In that study, samples were obtained from a ghost-rock endokarst, and were selected to represent a wide range of weathering intensities (Fig. 10). The samples followed a stratigraphic continuity to ensure the homogeneity of the original bedrock. Its measured properties demonstrate that it is a compact limestone (density of $\sim 2.65 \mathrm{~g} / \mathrm{cm}^{3}$ and porosity of less than $2 \%$ ), very pure (mass content of the $\mathrm{CaCO}_{3}$ is $\sim 98 \%$ ), impermeable (permeability of less than $0.6 \mathrm{mD}$ ), and it has a high resistance (a representation of the mechanical strength of the samples is given by resistance force to drilling - here it is more than $1000 \mathrm{~N}$ ) (Fig. 11). However, the petrophysical and mechanical properties of the limestone are greatly modified by the weathering. The grades I to $\mathrm{V}$ correspond to degrees of weathering that can only result from dissolution of the calcium carbonate - the resulting alterite is light (density is about $1.5 \mathrm{~g} / \mathrm{cm}^{3}$ ), highly porous (porosity of more than $45 \%$ ), permeable (permeability of about $10 \mathrm{D}$ ), and it has almost no
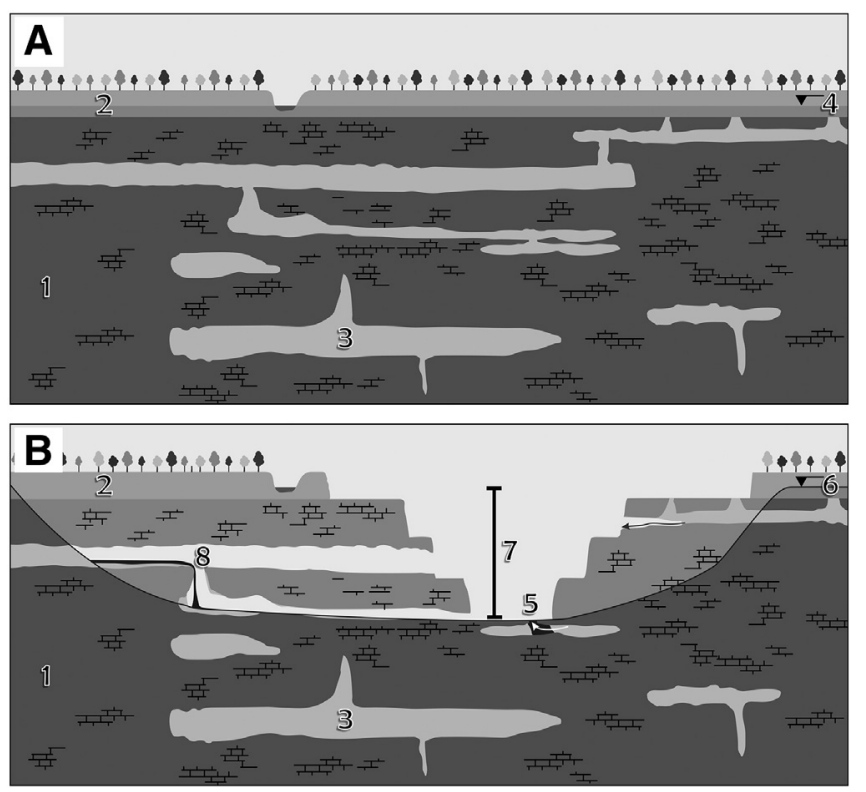

Fig. 14. The development of a ghost-rock karst network following an increase in the hydrodynamic potential. (A) The initial weathering network developed within the host limestone: (1) limestone; (2) overburden; (3) ghost-rock karst network; (4) natural piezometric level. (B) The creation of hydrodynamic potential due to quarrying of the limestone: (5) pumping; (6) artificial piezometric level caused by the pumping; (7) increased hydrodynamic potential; (8) removal of the alterite by flowing water. mechanical strength (resistance force $\sim 0 \mathrm{~N}$ ). It does, however, still consist mainly of $\mathrm{CaCO}_{3}(\sim 85 \%)$. In contrast, the $\mathrm{CaCO}_{3}$ content drops dramatically, to $40 \%$, at the centre of this weathering feature (grade VI). This zone appears to collect material inputs such as clay and organic matter although the reasons for this are not entirely clear. XRD analyses on crystallised minerals have shown a limestone mainly composed of calcite and, as the weathering proceeds, it decreases the calcite content and highlights secondary minerals (mainly quartz but also dolomite, gypsum, pyrite, and clays). XRD analyses on oriented aggregates have enabled the clay minerals to be determined. The fresh rock contains illite and trace kaolinite whereas smectite is detected in the weathered rocks and its concentration increases with increasing weathering intensity.

Furthermore, polished thin-sections of resin-impregnated samples were made to examine the effects of the weathering on the microstructure of the rock. They were analysed under optical and cathodoluminescence (CL) microscopy (Fig. 12). In fresh rock (\#130) the limestone matrix exhibits a dull brownish luminescence under $\mathrm{CL}$ and the crinoids show a dark CL. Diagenetic dolomite also occurs as bright red-luminescing rhombs scattered in the matrix of the rock and many of these rhombs exhibit bright yellow-luminescing spots concentrated along their outer rim. These spots constitute calcite replacing dolomite (dedolomite), which typically results from the exposure of dolomite to fluids with a low $\mathrm{Mg} / \mathrm{Ca}$ ratio such as meteoric water (Ayora et al., 1998). The porosity of the fresh rock cannot be resolved with this observation method. In moderately-weathered rock (\#20) the CL analysis reveals that all the dolomite rhombs have been dedolomitised, as demonstrated by their conspicuous bright yellow luminescence. It is not yet possible to recognise pores in the thin-section, due to their very small size, despite the fact that the petrophysical analyses indicate that the porosity of the sample should be about $30 \%$. In contrast, the highlyweathered rock (\#08) shows a network of very fine pores under optical microscopy. Most crinoids, about $90 \%$, present cracks that are influenced by cleavage planes and dedolomitisation affects the dolomite inclusions that are located along these cracks. The numerous dolomite inclusions scattered in crinoids result from diagenetic stabilisation of the magnesian calcite produced by echinoderms (Blake et al., 1984). The completely weathered rock (\#04 and \#02a-b) has a crumbly appearance due to the fact that a large part of the matrix has been dissolved and its fossils corroded. It is very obviously associated with a high porosity. Sample \#02b presents the transition from the completely weathered grade to the residual soil grade, during which the matrix calcite suddenly disappears. In the residual soil (\#02b-c and \#00) the matrix is no longer luminescent and the only remaining calcite is found in relic crinoids while gypsum crystals are observed as radiating needles (\#02c). There are also many quartz grains and kaolinite patches as indicated by a deep blue luminescence. However, in the very centre of the weathered zone (\#00), extraneous mineral deposits flank the pore and crack walls. These are mainly quartz with some zircons. Detrital grains and kaolinite are major components of the Lower Cretaceous clayey sands overlying the weathered limestone and it is, therefore, likely that they progressed 


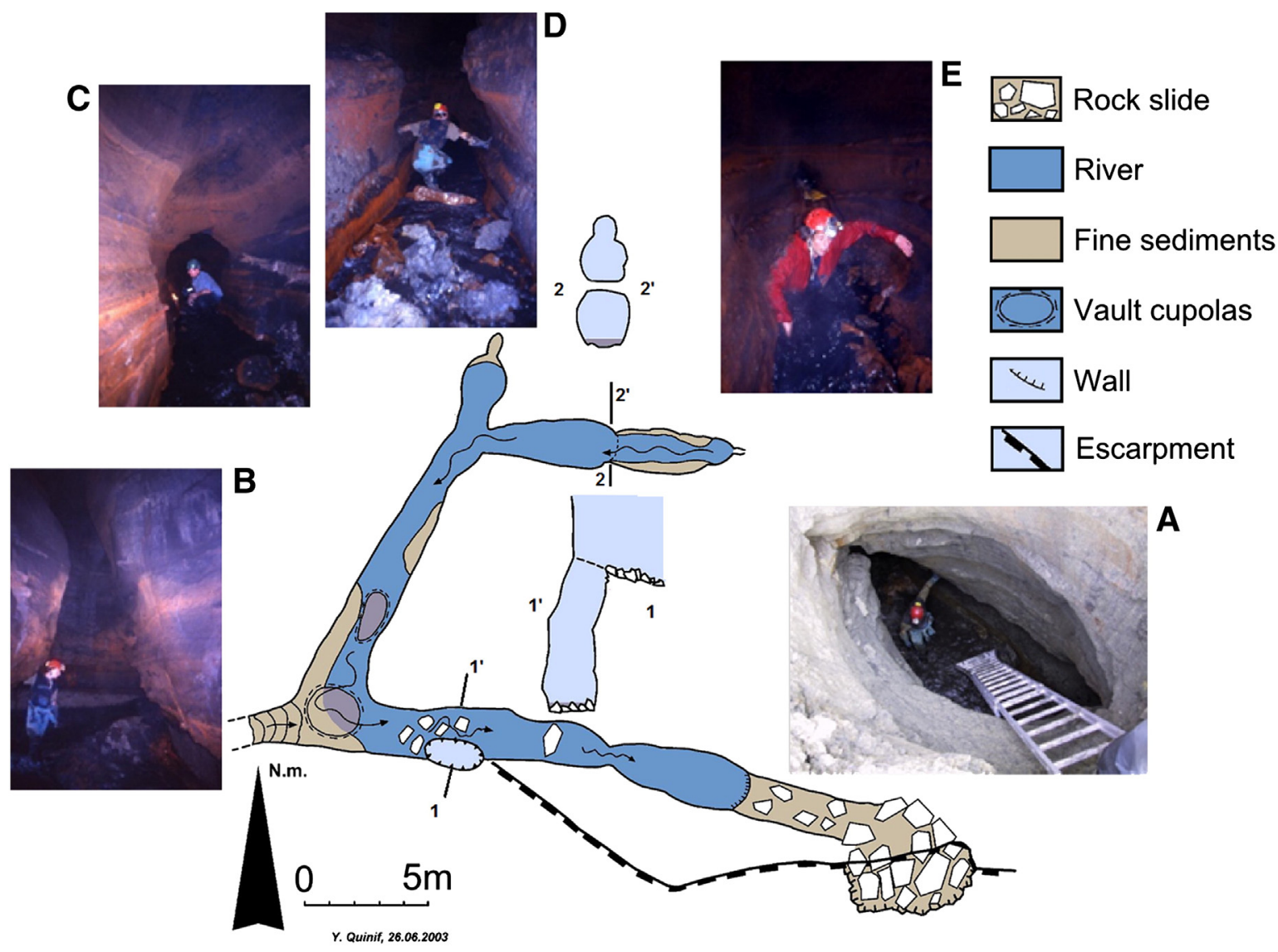

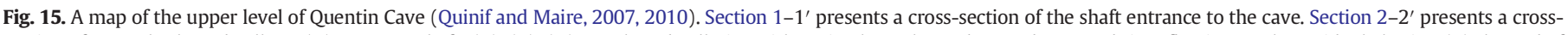

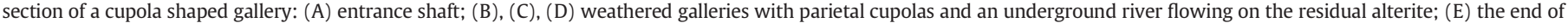
the gallery - the source of the underground river is located here within the alterite itself.

down open fractures in the limestone and were subsequently incorporated into the residual soil material. The gypsum is of secondary origin and forms as a result of the reaction between carbonate and the sulphuric acid produced by pyrite oxidation which is a common mineral in the Tournaisian limestone. Finally, scanning electron microscope analyses on samples from Gauthier-Wincqz Quarry, were conducted to complete this microscopic study (Havron et al., 2007). The SEM images of the fresh rock show calcite in the form of well-crystallised rhombohedra - crystals are interlocking and the rock structure is very compact with very few intergranular voids (Fig. 13A). In the completely weathered alterite the large calcite rhombohedra are affected by corrosion gulfs and the fine-grained calcite matrix exhibits numerous interconnected pores (Fig. 13B and C).

\subsection{Subsequent erosion of the ghost rock features}

The association between ghost-rock karstification and the development of cave systems was demonstrated for the first time at Nocarcentre Quarry (Quinif and Maire, 2007, 2010). The quarry acts as a natural laboratory because the operation area has to be dewatered in order for the

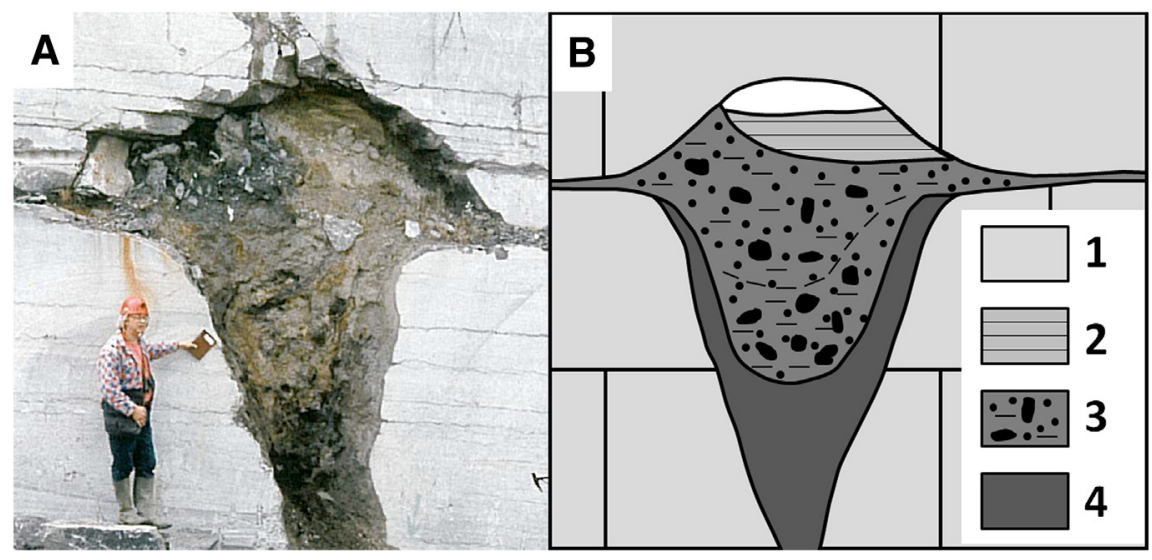

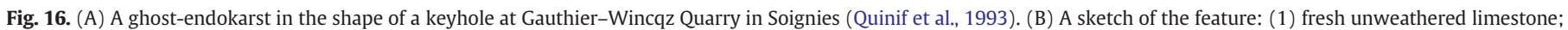
(2) stratified silt deposits; (3) a thin fluvial deposit with highly weathered quartz pebbles; (4) the remaining residual alterite resulting from ghost-rock karstification. 


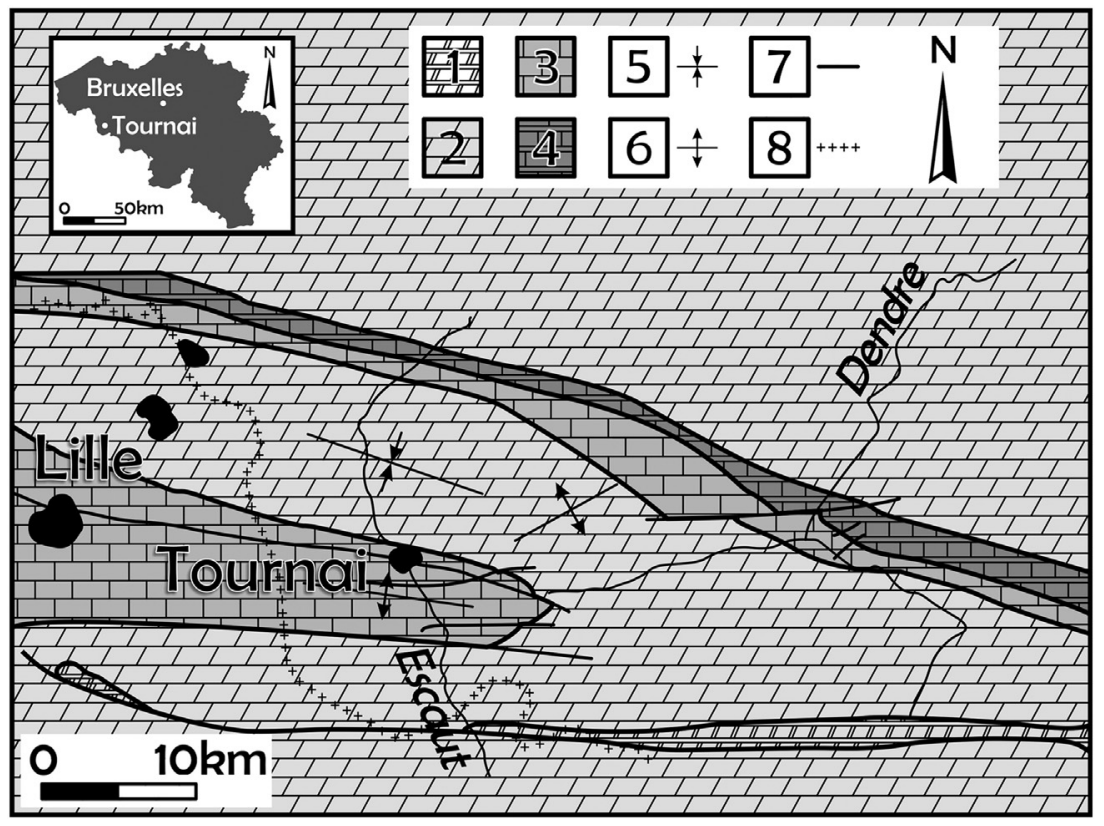

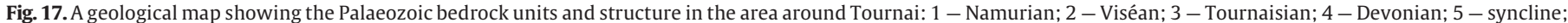
6 - anticline; 7 - fault; 8 - national boundary.

limestone to be extracted. Therefore, while pumping, the piezometric surface is artificially lowered which leads to dewatering of the ghost-rock features and increases the hydrodynamic potential Fig. 14. The second stage of the ghost-rock karstification process, regressive mechanical erosion of the alterite, is artificially triggered by anthropogenic modification of the water table. During 50 years of mining, regressive erosion of the alterite has excavated a network of galleries with a total length of around $100 \mathrm{~m}$ that together comprise Quentin Cave (Fig. 15). These galleries have developed along fractures and they occur at several levels connected by vertical shafts (Fig. 15A) while their walls, especially those of the large galleries, are characterised by cupolas (Fig. 15B and C). The river responsible for excavating the alterite flows through the galleries on a thick layer of residual material (Fig. 15D) and its source is located in an impenetrable sump within the alterite itself (Fig. 15E). The erosion of the alterite progressed to the extent that, in just a few months, the river abandoned its original gallery in favour of a lower gallery. This example clearly illustrates that cave systems are able to develop over several levels without needing a corresponding change in base level.

In Gauthier-Wincqz Quarry, a more complicated type of ghost-rock endokarst feature can be observed. This has the morphology of a keyhole (Fig. 16) and the filling material is characterised by three distinct units (Quinif et al., 1993, 2012). The uppermost unit comprises stratified silts which unconformably overlie the underlying deposits, the middle unit comprises fluvial deposits in which large weathered quartz pebbles are found within a finer matrix, and the lowermost unit comprises the remaining alterite derived from the weathering of the surrounding limestone. It has been compacted due to the weight of the overlying sediments. The analysis of the material encased within this ghost-rock endokarst feature demonstrates that it was, at one time, an empty gallery through which water flowed. It is not possible to say with certainty how this gallery formed. The flow must have had sufficient hydrodynamic energy to carry the pebbles and, therefore, it is reasonable to assume that any residual alterite had already been excavated. However, the pebbles are now highly weathered and they could not have been transported in this state by the stream. Therefore, it appears that both weathering of the pebbles and weathering of the underlying limestone occurred after the creation of an open gallery. This example suggests that, if the right hydrodynamic conditions are met, alterite can be produced after the creation of an open void irrespective of whether the void formed as a result of karstification by total removal or by ghost-rock karstification.

\subsection{A summary of the results in terms of ghost-rock karstification}

(1) Lithology: limestone and dolomitic limestone from the Upper Tournaisian.

(2) Initial conditions: the initial permeability of the bedrock was conditioned by a phase of tectonic extension between the Upper Jurassic and Lower Cretaceous (Vandycke and Bergerat, 1989; Vandycke, 2002). This created open vertical joint sets: $\mathrm{N} 60^{\circ} \mathrm{E}$, $\mathrm{N} 150^{\circ} \mathrm{E}$ and $\mathrm{N} 110^{\circ} \mathrm{E}$.

(3) Timing of ghost-rock karstification: during emergence in the Upper Jurassic and Lower Cretaceous.

(4) Chemical energy: there was abundant chemical energy due to the hot and wet climate.

(5) Hydrodynamic energy: there was only low hydrodynamic potential due the subdued relief.

(6) Subsequent development:

(1) Thanetian: marine transgressions during which the karst becomes a palaeokarst;

(2) Danian: a disturbance, probably tectonic, generated underground flow. Some of the pseudoendokarsts were emptied of their alterite and replaced by a fluvial detrital series (Quinif et al., 2006). Caves with cupolas of metric dimensions formed and were then fossilised by transgressions during the Thanetian and Ypresian;

(3) Present: quarrying and pumping has lowered the piezometric level and created new hydrodynamic potential so that, in the quarries, the ghost-rock features are emptied to become speleological caves. In other places, the alterite compacts, leading to the formation of sinkholes.

\section{Ghost-rock karstification in other geological settings}

This section presents a series of case studies that have investigated ghost-rock features across western Europe. These case studies come from geologically distinct parts of Belgium, France, Italy, and the 


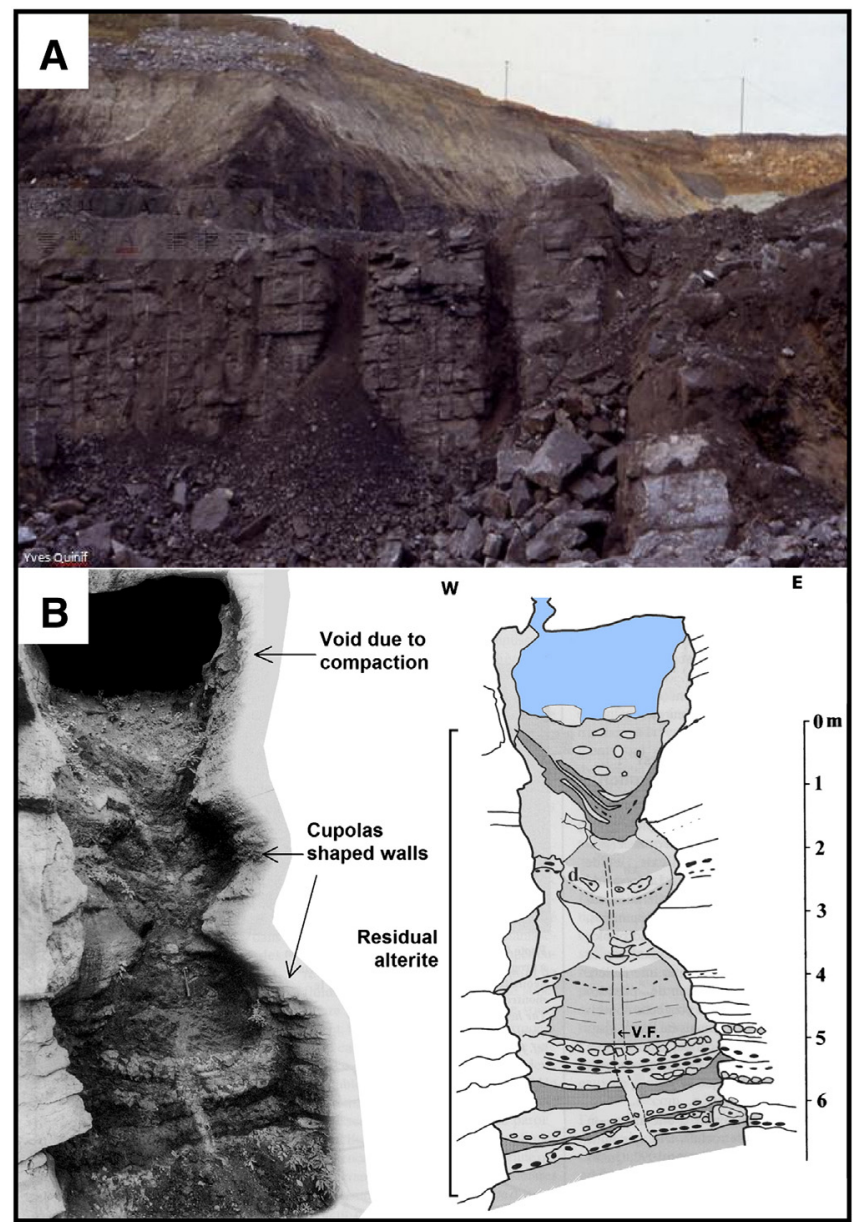

Fig. 18. (A) Weathered corridors at Hainaut quarry in Soignies. (B) "Pic-à-glace" Cave at Milieu Quarry in Tournai. This ghost-rock feature is surrounded by fresh unweathered limestone and there is an abrupt transition from the fresh rock to the alterite-specific markers can be followed from the fresh rock through the alterite. A void has been created at the top of the feature due to compaction of the alterite under the influence of its own weight. The trace of the original vertical joint (marked V.F.) is visible in the centre of the feature.

Panel B is modified from Vergari (1998).

United Kingdom. Each offers an outline of the regional geology, a description of the ghost-rock features, and a summary of the available analytical results. It is clear that ghost-rock karstification affects several lithologies and that the weathering process may produce a range of karst features. In addition, the structure and organisation of ghostrock networks are emphasised.

\subsection{Belgium}

\subsubsection{The Tournaisian siliceous limestone of Tournai}

The city of Tournai is located in southwest Belgium close to the border with France (Fig. 17). The bedrock in this region consists of Lower Carboniferous Tournaisian limestone overlain unconformably by deposits from the Mesozoic and Cenozoic (Hennebert and Doremus, 1997a,b). This dark micritic limestone includes many chert beds. It also incorporates a three-dimensional interstitial network that comprises $12 \%$ microcrystalline silica and $8 \%$ clay. It has long been known that this argillaceoussand network remains intact as calcium carbonate dissolution proceeds during weathering (Camerman, 1947). The bedrock structure results from oblique dextral compression during the late-Hercynian and the central part of the region comprises the faulted anticline of MelantoisTournaisis. In this region the formations dip sub-horizontally while major right-lateral strike-slip faults trend from east to west. These limestones form part of the great Carboniferous aquifer of Wallonia.

The ghost-rock karst features in this region are represented by weathered corridors and ghost-palaeokarsts filled with their alterite. The corridors are aligned according to the fracture directions and they may attain widths of up to $10 \mathrm{~m}$ along with depths and lengths of several tens of metres. The ghost-palaeokarst encountered at "Pic-à-glace Cave", discovered during quarrying, represents the historical karstotype for ghost-rock karstification (Fig. 18). It has a height of $7 \mathrm{~m}$ and a variable width from 1 to $3 \mathrm{~m}$ (Vergari, 1996, 1998). The residual alterite still remains in the ghost-palaeokarst although it has been deformed slightly due to compaction under its own weight caused by dewatering of the quarry. This has led to the formation of a void at the top of the ghost-palaeokarst. It is clear that specific levels, in particular the chert beds, can be traced from the fresh rock through the alterite while the initial fracture is still recognisable in the centre of the feature. The walls of this ghost-palaeokarst are shaped with cupolas.

The fresh rock and the alterite at the centre of Pic-à-glace Cave have been subjected to petrophysical analyses (Kaufmann et al., 1999; Kaufmann, 2000). The density of the fresh rock is about $2.8 \mathrm{~g} / \mathrm{cm}^{3}$ while its porosity is almost zero. In contrast, the density of the alterite drops to $0.9 \mathrm{~g} / \mathrm{cm}^{3}$ while its porosity increases to $65 \%$. The ratio of $\mathrm{Ca} / \mathrm{Si}$ is 2.2 for the fresh rock and 0.05 for the alterite while the ratio of $\mathrm{Al} / \mathrm{Si}$ goes from 0.15 in the fresh rock to 0.1 in the alterite. These results reflect carbonate dissolution leaving a siliceous skeleton. The SEM analyses on a sample of fresh rock and a sample of alterite (Fig. 19) show an almost complete loss of calcite (Kaufmann et al., 1999). The weathering process induces high interconnected porosity while leaving a framework of silica grains that ensures the mechanical stability of the alterite.

\subsubsection{The Dinantian oolitic limestone of Engis}

The town of Engis is located near the city of Liège in eastern Belgium. The bedrock consists of a tectonised lens of Dinantian limestone (Fig. 20)
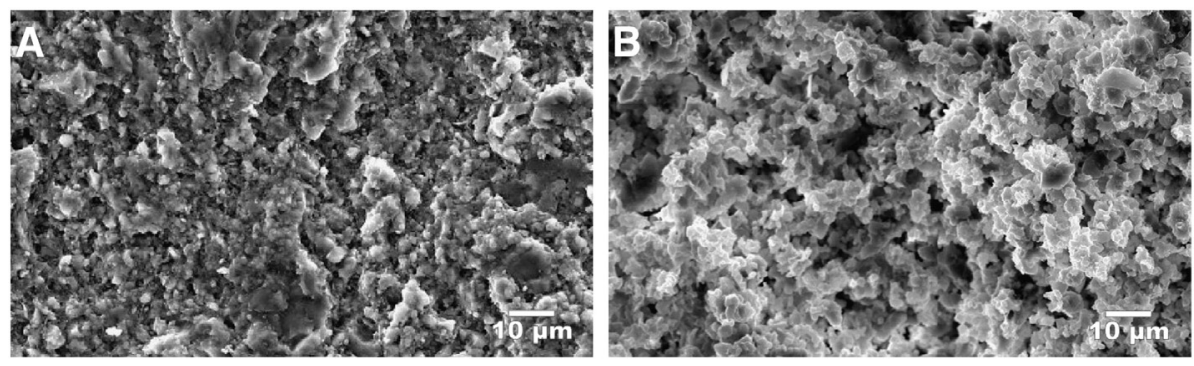

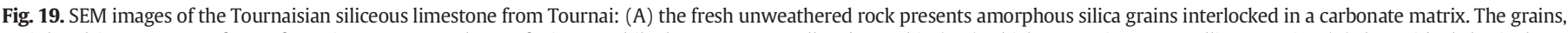

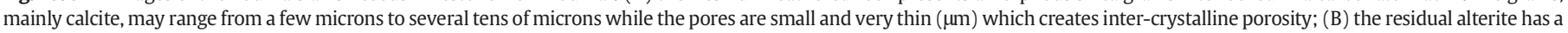

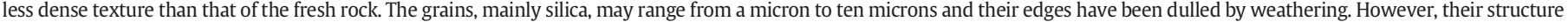

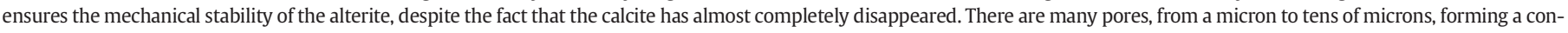
nected network. 


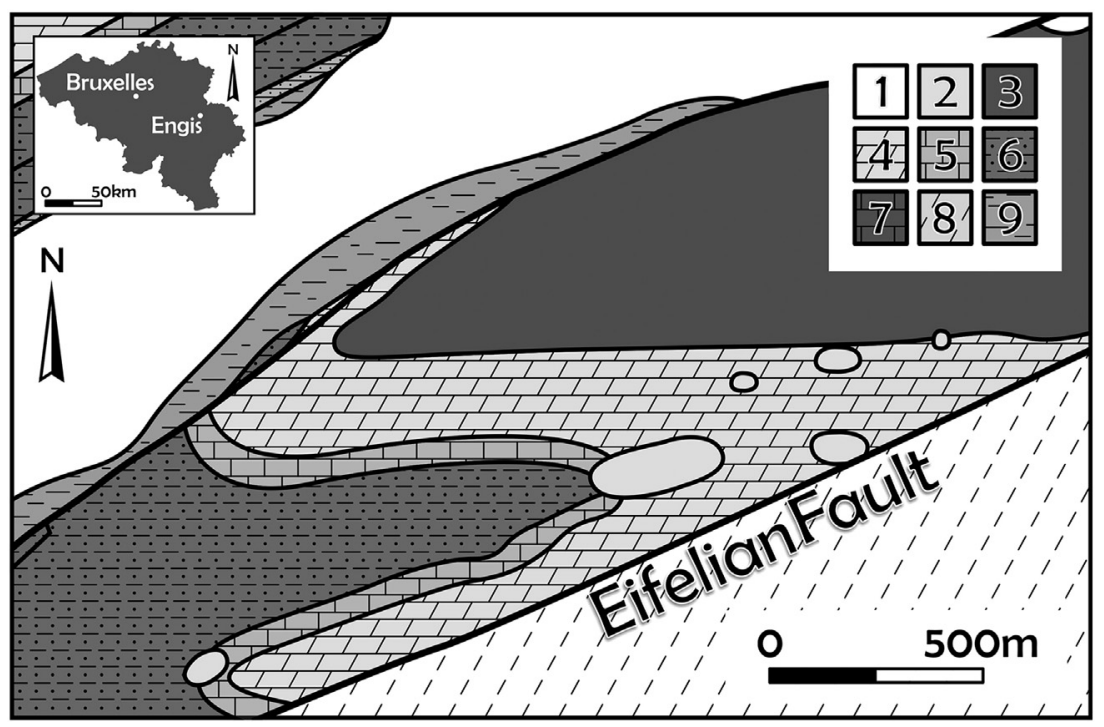

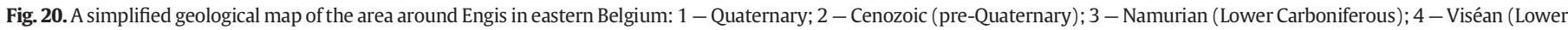
Carboniferous); 5 - Tournaisian (Lower Carboniferous); 6 - Upper Devonian; 7 - Middle Devonian; 8 - Lower Devonian; 9 - Silurian. Modified from Stainier (1899).

wedged between the Eifelian Fault to the south and the Yvoz-Ramet Fault to the north (Quinif et al., 2011). The limestone beds are massive with sub-vertical dips while it is cut by two main joint sets: $110^{\circ} \mathrm{N}$ and $\mathrm{N} 25^{\circ} \mathrm{W}$. In this region the formations affected by ghost-rock karstification are very pure oolitic and bioclastic limestones. The weathering is represented by a maze of weathered strips that follow both the stratification and the two joint sets (Fig. 21). These strips have widths ranging from few decimetres to several metres and they are filled with a macroscopically powdery, loose, and friable residual alterite. A series of six samples were obtained from a ghost-rock feature that has developed from a stratification bed (Fig. 21). Due to the fact that the weathering spread from the bedding plane into the stratum, the samples taken to represent different weathering states are not in stratigraphic continuity, but are instead perpendicular to it.

The mineralogical and petrophysical properties of these samples have been analysed in order to assess their development according to the weathering intensity (Fig. 22). The fresh rock is represented by the following values, given by the quarry: density $=2.55 \mathrm{~g} / \mathrm{cm}^{3}$; porosity $=0.5 \%$; and mass content in $\mathrm{CaCO}_{3}=99 \%$. In contrast, analyses of the alterite shows that these values have decrease to: density = $1.4 \mathrm{~g} / \mathrm{cm}^{3}$; porosity = c. $50 \%$; and mass content in $\mathrm{CaCO}_{3}=79 \%$. These results reflect an intermediate weathering state in which the weathering process stopped before the carbonates were completely dissolved and before the arrival of exogenous material. In contrast to that described from Pic-à-glace Cave there has been no compaction of the alterite at this site. XRD analyses of crystallised minerals show a limestone essentially composed by calcite and in which the calcite content decreases as a result of weathering. These analyses highlight that quartz represents the only impurity while analyses on oriented aggregates highlight that illite represents the only clay mineral found in each weathering state.

Thin sections of samples were prepared and analysed under cathodoluminescence microscopy (Fig. 23). The slightly weathered rock (\#150) has a very complicated structure. It is composed of a very thin and heterogeneous calcareous matrix while the disc-shaped components are oolites. Drying forms are visible around the oolites, which probably date from sedimentation or diagenesis of the limestone, while calcite has subsequently crystallised in these open pores. The fractures developed later and affect the whole rock. The moderately weathered rock (\#50) is less luminescent. The duller areas correspond to the development of porosity as a result of dissolution of the matrix while the clastic quartz crystals, shown in dark blue, are cemented to the carbonate matrix by diagenetic quartz. The completely weathered rock (\#0) is mainly non-luminescent. The well crystallised calcite is brighter while the matrix shows dissolution features that reveal secondary porosity.

\subsection{France}

\subsubsection{The Rupelian bioclastic limestone of Aquitaine}

Entre-deux-Mers is located in the Aquitaine region of southwest France (Fig. 24). The region comprises a limestone plateau dating from

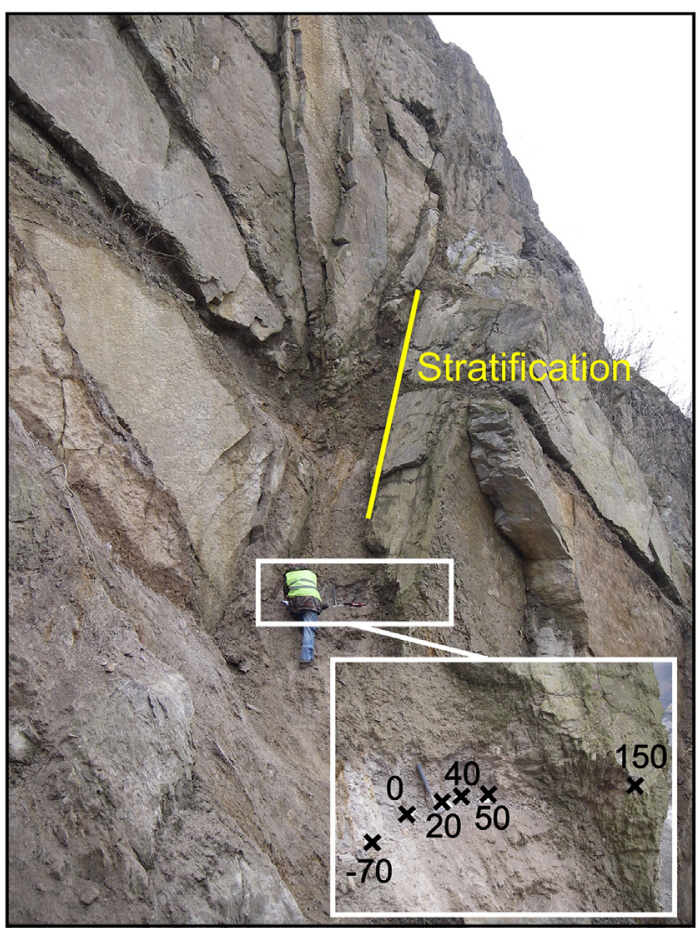

Fig. 21. The weathered zone selected for sampling in the Dinantian limestone at Engis Quarry. The six samples were taken to represent different weathering states and they are identified by their distance, in $\mathrm{cm}$, from the centre of the weathering feature: (\#150) slightly weathered rock; (\#50) moderately weathered rock; (\#40) and (\#-70) highly weathered rock; (\#20) and (\#0) completely weathered rock. 

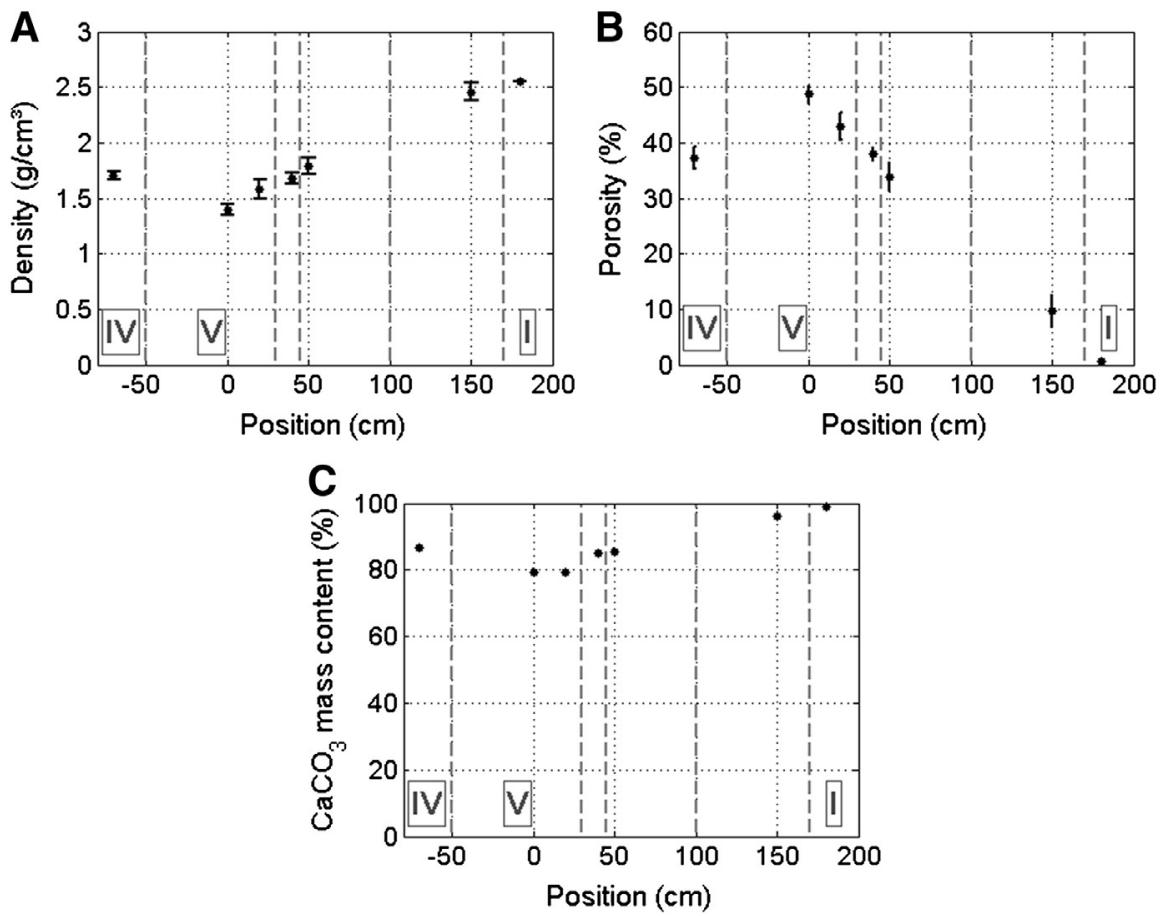

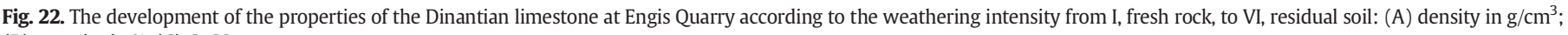
(B) porosity in \%; (C) $\mathrm{CaCO}_{3}$ mass content.

the early Oligocene (Rupelian) whose formations reflect repetitive emergence and submergence of the carbonate shelf. They are subhorizontally stratified and present numerous lateral facies variations along with a large number of sedimentary structures (Dubreuilh, 1976; Klingebiel et al., 1993; Lans et al., 2006). The karst phenomena affect the "Calcaire à Asteries" limestone formation, which is situated between two impervious formations, the underlying late Eocene "Fronsadais Molasse" (Priabonian) and the overlying late Oligocene "Agenais Molasse" (Chattian). The composition and texture of this highly fossiliferous rock varies greatly although, in general, it is friable and porous due to its weak diagenesis. The karst phenomena are reflected by two features: speleological caves and ghost-rock features filled their alterite, visible in the quarries of the region.

The cave galleries are horizontal and comprise loss-resurgence systems crossed by an underground river. The karst network "Trou de la Barrique" presents galleries whose morphology helps to show the transition from ghost-rock feature to speleological cave (Fig. 25). The upper part of the gallery is characterised by a lens shape whose horizontal extension follows a weathered stratum while the lower part is characterised by lateral banquettes and potholes. It is proposed that part of the alterite from the weathered stratum was initially removed by mechanical erosion, thereby creating a pipe, whose subsequent development can be regarded in classic fluvial terms - the pipe was overdeepened by a subsurface flow of water. The ghost-rock features seen in the quarries of the region are represented by horizontal galleries, connected by vertical joints, with heights from one to several metres and lengths of sometimes more than $100 \mathrm{~m}$ (Dubois et al., 2011). In cross-section they bear a striking morphological similarity to speleological cave galleries (Fig. 26). These features initially developed from more porous zones within the rock.

A series of three samples were taken from a ghost-rock feature in Piquepoche Quarry. The mineralogical and petrophysical analyses show an increase in porosity which implies a decrease in the density and proportion of $\mathrm{CaCO}_{3}$ (Fig. 27). The composition of the "Calcaire à Astéries" limestone was obtained by XRD. For all weathering intensities, the limestone only comprises calcite and quartz while it can be seen that the weathering leads to a relative increase in the quartz content. Furthermore, the clay-XRD spectrum shows that each sample contains illite, kaolinite, and smectite. Thin sections of samples were prepared and analysed under optical microscopy (Fig. 28). The slightly weathered Sample \#1 shows a considerable number of fossils and rolled grains composed of calcite, poorly cemented by a calcareous micrite. There is significant primary porosity between the grains as a result of the weak rock diagenesis while the voids are lined with sparitic calcite
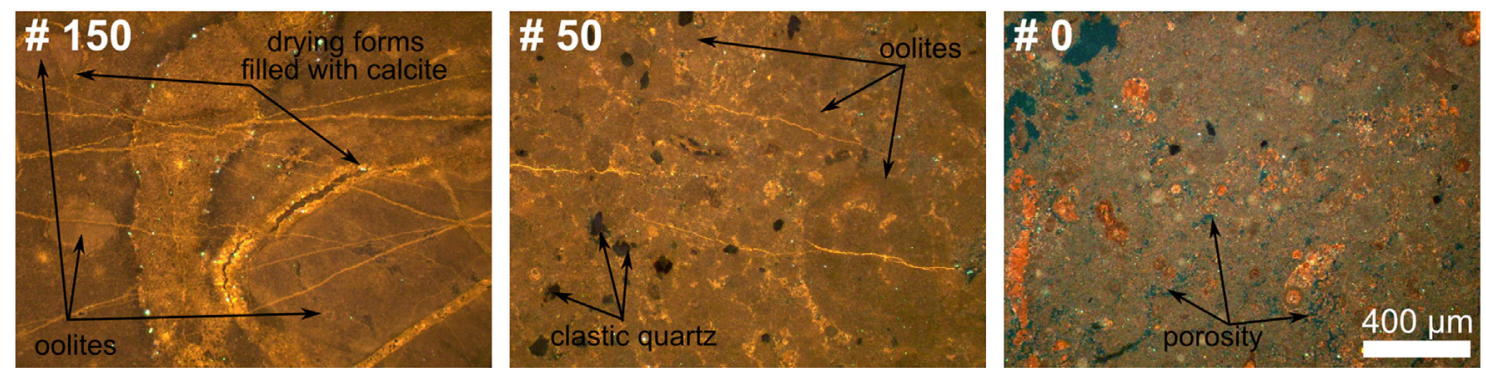

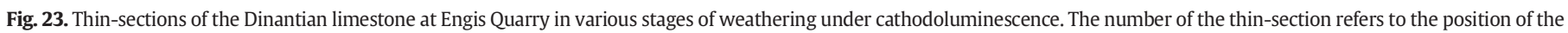
sample, in $\mathrm{cm}$, relative to the centre of the weathered feature: (\#150) slightly weathered rock; (\#50) moderately weathered rock; (\#0) completely weathered rock. 
crystals. The weathered Sample \#3 shows an increase in the porosity both by the number and size of voids and by the appearance of small voids in the fossils and matrix - these voids are connected to form microkarsts. The microscopic structure of both the rock and the fossils has also been erased in this sample while the majority of pores are bordered by ocher clays (clay coatings). These clays locally impregnate the micrite and underlie the fossils.

\subsubsection{The Mid-Jurassic limestone of Burgundy}

Macon and Cluny are located at the northeastern boundary between the Massif Central and the plain of the Saone (Perthuisot, 1966; Barusseau, 1967; Rat, 2006; Dechamps, 2011). The region comprises Palaeozoic basement consisting of granitoids and sedimentary rocks overlain unconformably by sediments from the Mesozoic which are then, in turn, overlain unconformably by fluviolacustrine sediments from the Cenozoic (Fig. 29). It has been subjected to two extensional stages during or after the Mesozoic (Quesne et al., 2000). The first occurred from the Aalenian to the Bajocian in association with rifting of the Piemont-Liguria Ocean and is characterised by normal microfaults with metre-scale slip and shallow dips $\left(40-60^{\circ}\right)$. The second occurred in the Oligocene and corresponds to the establishment of the Bressan Graben - this period represents a general phase of extension across certain parts of western Europe during which a number of grabens formed (i.e. the Rhine Graben and the Forez Graben). This phase of east-west extension is responsible for the current structure in which tilted blocks dip towards the Saone in Macon. This tilting was accommodated along unconformable normal faults that generally trend in a north-south direction $\left(\mathrm{N} 10-20^{\circ} \mathrm{E}\right)$. These steeply dipping faults $\left(70-80^{\circ}\right)$ are predominately Hercynian structures reactivated by new contemporary stress fields in the Cenozoic. The karst phenomena affect the carbonates dating from the Middle Jurassic while the ghost-rock features are observed in relation to both tectonic episodes.

In the quarry of La Salle (Fig. 30A) ghost-endokarst features are found in Upper Aalenian to Bajocian crinoidal limestones and these are associated with joints developed in the Jurassic. The transition from fresh rock through slightly weathered rock and on to completely weathered limestone has been observed in several places. The alterite comprises $49 \%$ silt and $41 \%$ sand while the coarsest fractions consist

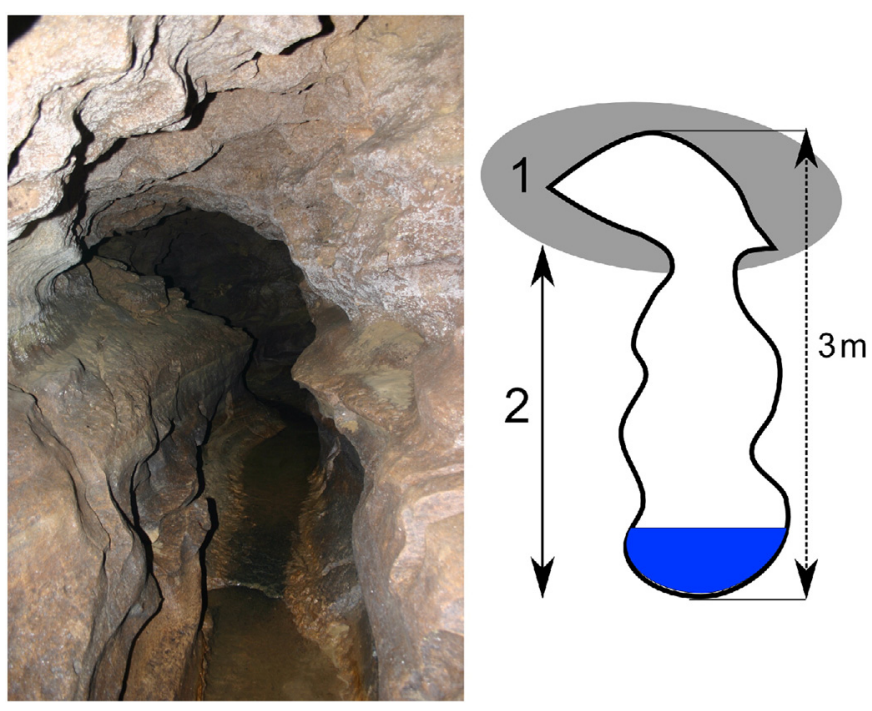

Fig. 25. A gallery in the cave "Trou de la Barrique": (1) the widening at the top of the section has developed along stratum affected by chemical dissolution; (2) the overdeepened part of the section, and its banquettes, result from subsequent fluvial evolution.

only of fossil debris. It is thought that the tectonic block movements during the Oligocene caused some of the ghost-rock features to be emptied of their alterite including that which created the "well with ribs" of Macon (e.g. Donzy Perthuis (Fig. 30B)).

The endokarst of Azé represents the downstream part of a lossresurgence system oriented north-south following the direction of the main geological structures (Guillot et al., 2005). It comprises two parallel galleries that exit onto a valley slope (Fig. 31). The shorter of these, Dry Cave, runs for $436 \mathrm{~m}$ in Upper Bajocian to Lower Bathonian limestone. In many parts of the Dry Cave there are significant fluvial deposits and cave formations that almost completely obstruct the galleries which are rich in paleontological and prehistoric remains (Barriquand et al., 2011a). The most common underground forms are metre-size parietal cupolas that have often merged together to give a characteristic "cloche

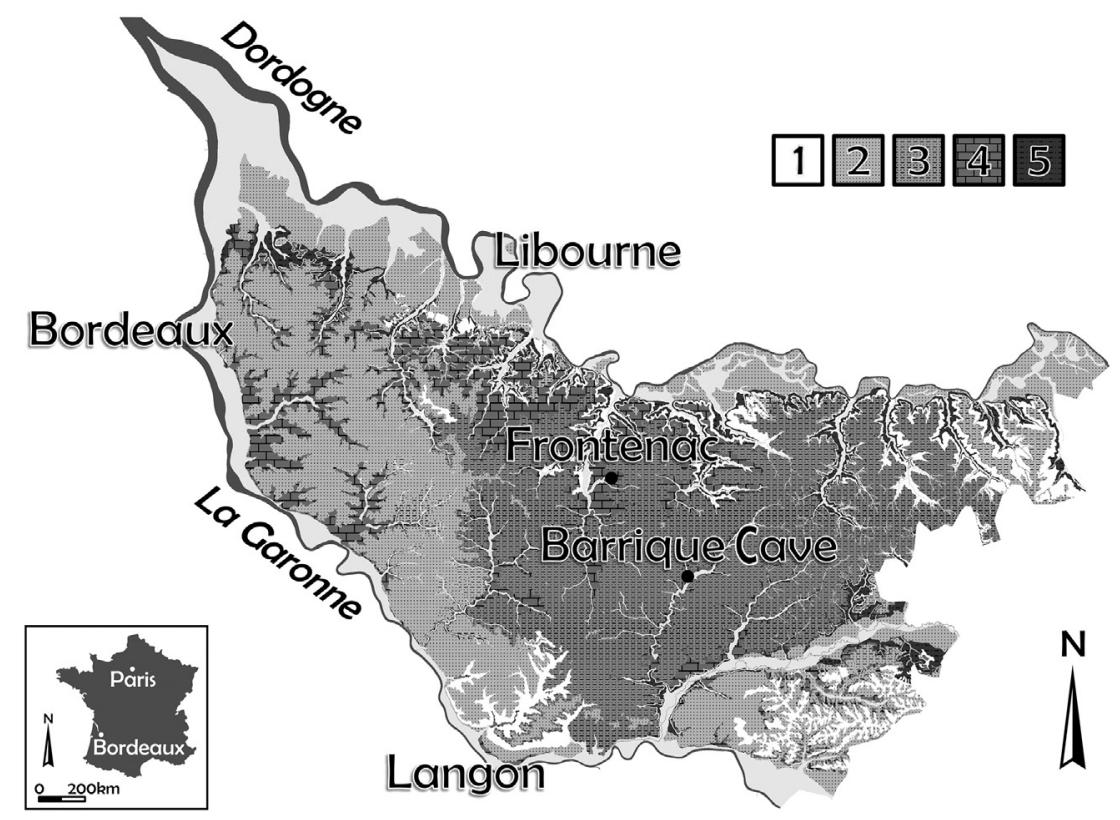

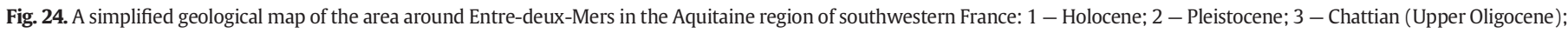
4 - Rupelian (Lower Oligocene); 5 - Upper Eocene.

Modified from Cellule Cartographie/SIG (2008). 


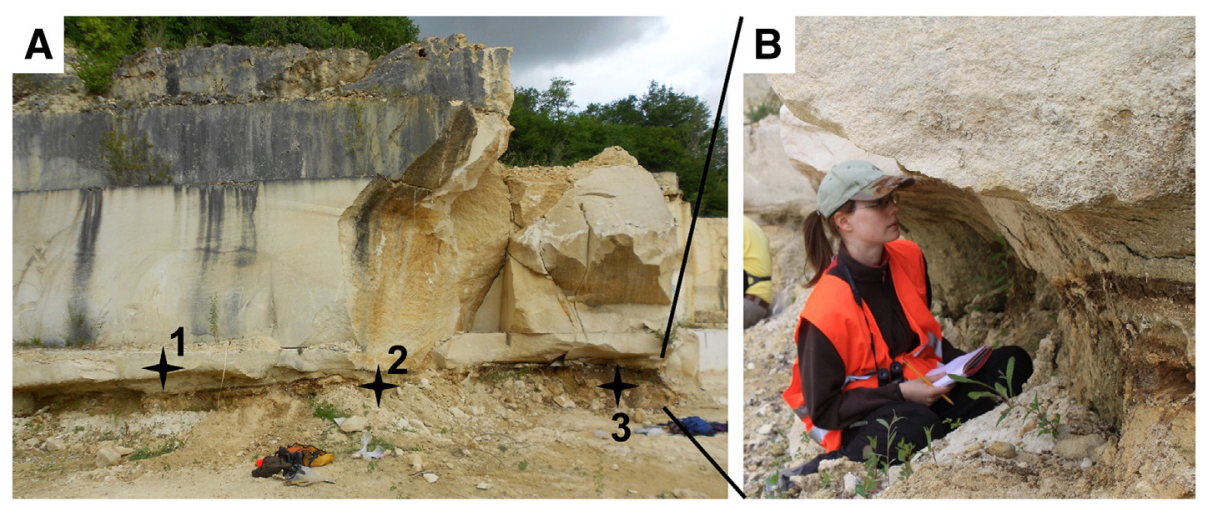

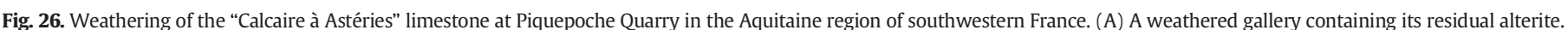

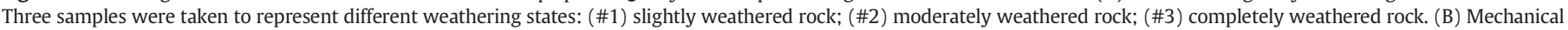
erosion of the alterite results in a feature that looks like a speleological gallery.
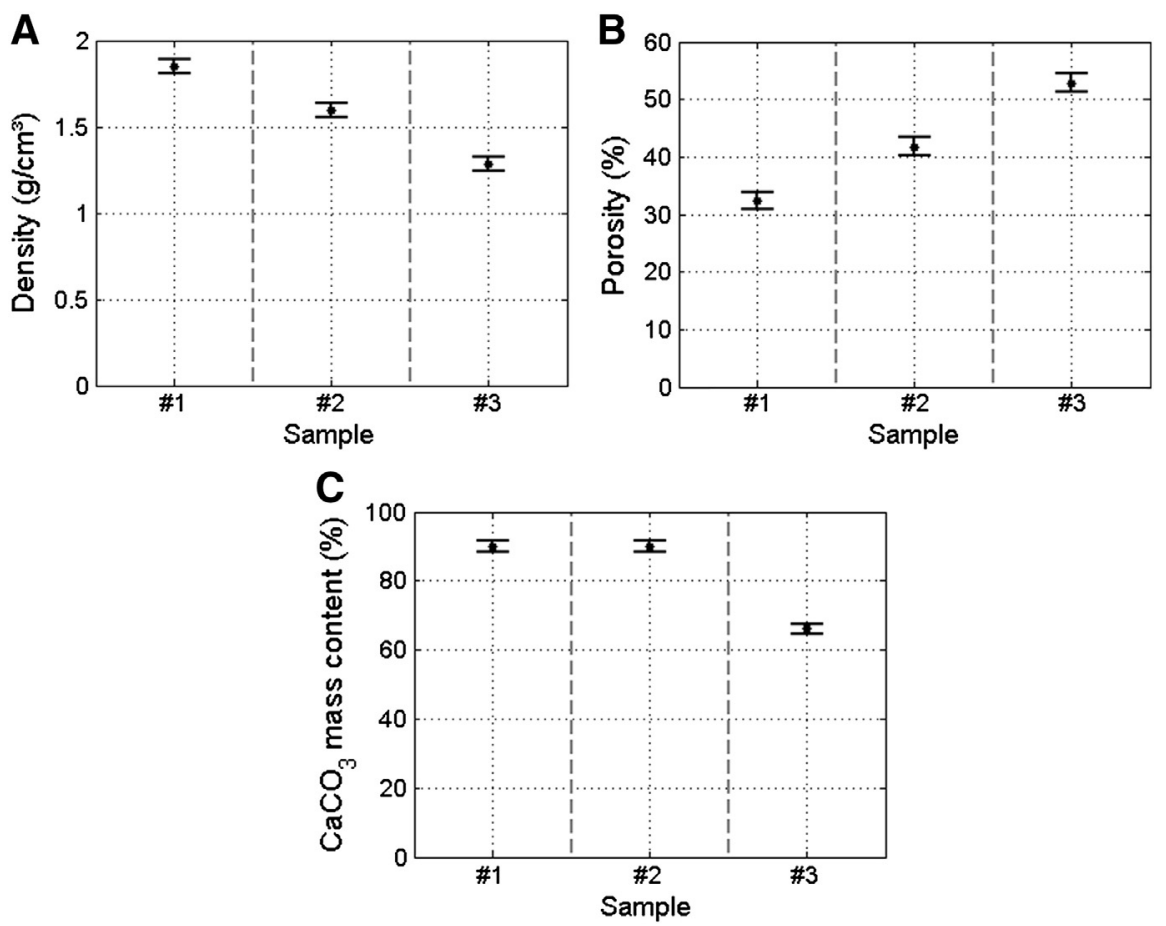

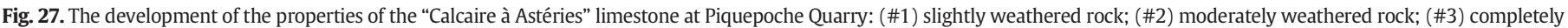
weathered rock; (A) density in $\mathrm{g} / \mathrm{cm}^{3}$; (B) porosity in \%; (C) $\mathrm{CaCO}_{3}$ mass content.
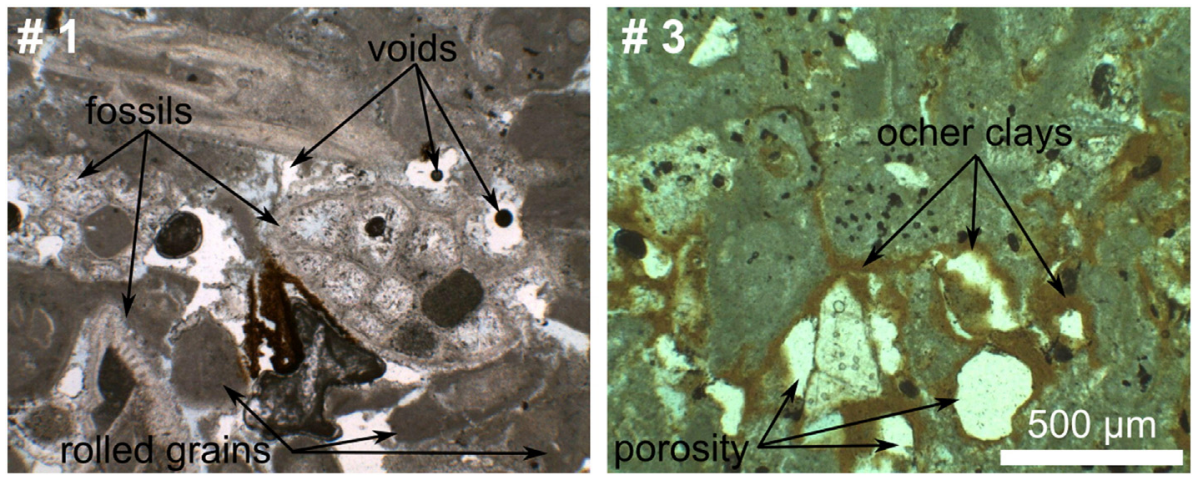

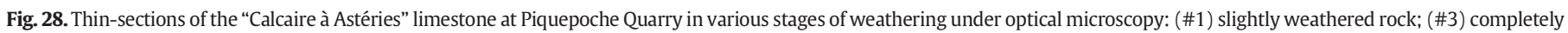
weathered rock 
vault' morphology. In several places differential chemical corrosion has released fossils that are chemically stronger than the surrounding rock. The main gallery in the prehistoric cave is terminated by fluvial deposits. However, as the cave is particularly valuable for paleontological and prehistoric remains, cavers decided to dig a gallery parallel to the fluvial deposits. This ran for several tens of metres in a loose material that was later found to be residual alterite (Fig. 32A) (Bonnefoy, 2002; Barriquand et al., 2011a,b). This discovery confirmed that ghost-rock karstification was responsible for the origin of the cave (Quinif, 2010a, b, 2011; Barriquand et al., 2012). Furthermore, while the fluvial deposits typically comprise fluvial sediments such as sand and pebbles, there are also blocks of residual alterite as confirmed though optical microscopy and XRD (Barriquand et al., 2012).

The longer of the two parallel galleries, Cave of the Underground River, runs for $1256 \mathrm{~m}$ in Upper Aalenian to Lower Bajocian limestone (Dechamps, 2011). In this cave another path, this time to improve the tourist infrastructure, was dug in alterite and thereby confirmed that ghost-rock karstification was also responsible for the origin of this cave. The alterite on the walls of the Cascade Room is several centimetres thick (Fig. 32B). The microscopic analyses of this alterite shows that the micrite has completely disappeared and that only the sparitic calcite and quartz crystals remain (Fig. 33) (Barriquand et al., 2012). Furthermore, it has been shown that the created porosity is partially filled by ferromanganese bacterial deposits (Papier et al., 2011). The loss of material due to ghost-rock karstification is not only marked by an increase in porosity but also a decrease in density from $2.52 \mathrm{~g} / \mathrm{cm}^{3}$ to $1.85 \mathrm{~g} / \mathrm{cm}^{3}$.

\subsubsection{The Kimmeridgian oolitic limestone of Charente}

The region of Charente is located in southwestern France in the northeastern part of the Aquitaine Basin at the contact with western edge of the Massif Central. Its bedrock is dominated by a massive Jurassic carbonate platform with a low dip to the southwest (Fig. 34). The karst phenomena are concentrated around La Rochefoucauld, one of the largest French karst areas $\left(550 \mathrm{~km}^{2}\right)$, situated between the city of Angoulême to the west and the town of Montbron to the east. This karst area comprises a series of three plateau surfaces that slope gently to the west at elevations of between 250 and $120 \mathrm{~m}$ asl. The only known

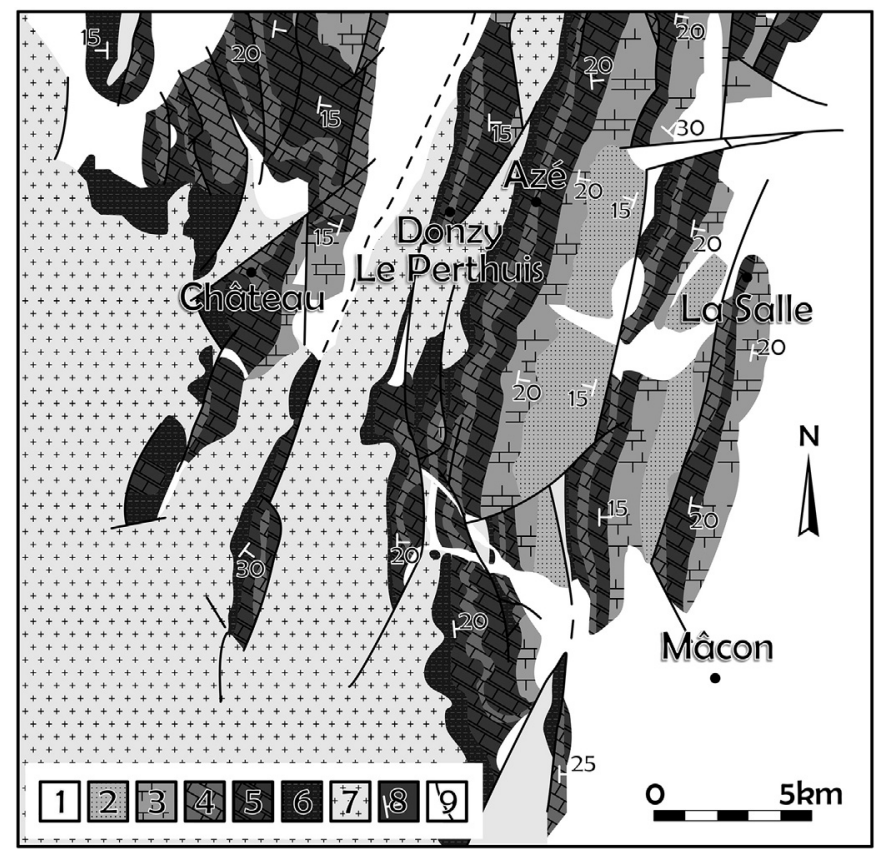

Fig. 29. A simplified geological map of Mâcon and Cluny (Quesne et al., 2000): 1 - Alluvium; 2 - Cenozoic; 3 - Late Jurassic; 4 - Middle Jurassic; 5 - Early Jurassic; 6 - Triassic; 7 Palaeozoic; 8 - dips; 9 - faults.

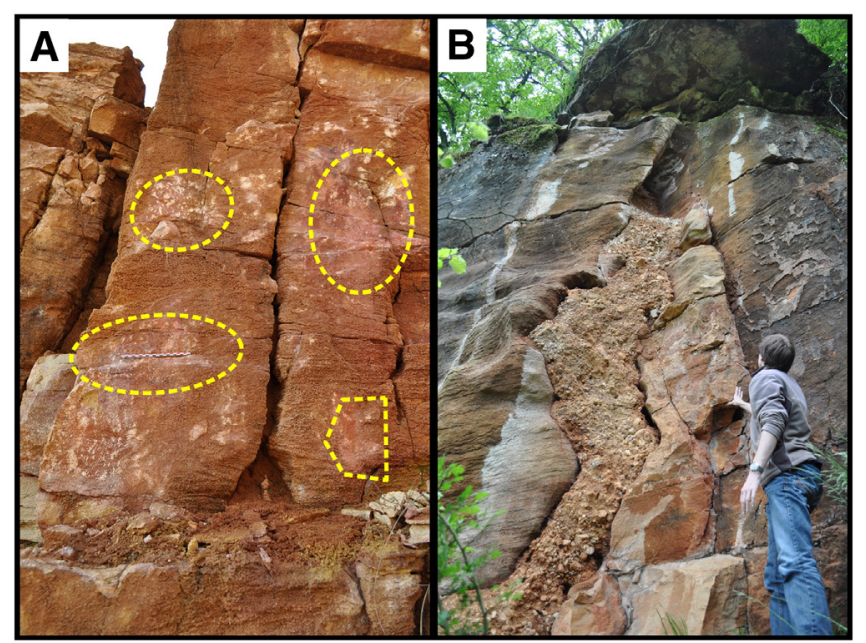

Fig. 30. (A) The Upper Aalenian limestone in the quarry of La Salle in the region of Saôneet-Loire in eastern France. The process of ghost-rock karstification has produced areas of fresh limestone (circled yellow), weathered limestone, and residual alterite. (B) The Lower Bajocian limestone in the quarry of Donzy Le Perthuis. The hydrodynamic potential needed to remove the alterite was created as a result of tectonic activity in the Oligocene and these features when then later filled with fluvial deposits.

outlet is represented by the Touvre Springs which is the second biggest resurgence in France $\left(13 \mathrm{~m}^{3} / \mathrm{s}\right)$ after Fontaine-de-Vaucluse in ProvenceAlpes-Côte d'Azur. The catchment mainly comprises Middle and Upper Jurassic micritic oolitic limestone cemented by sparitic crystals. This

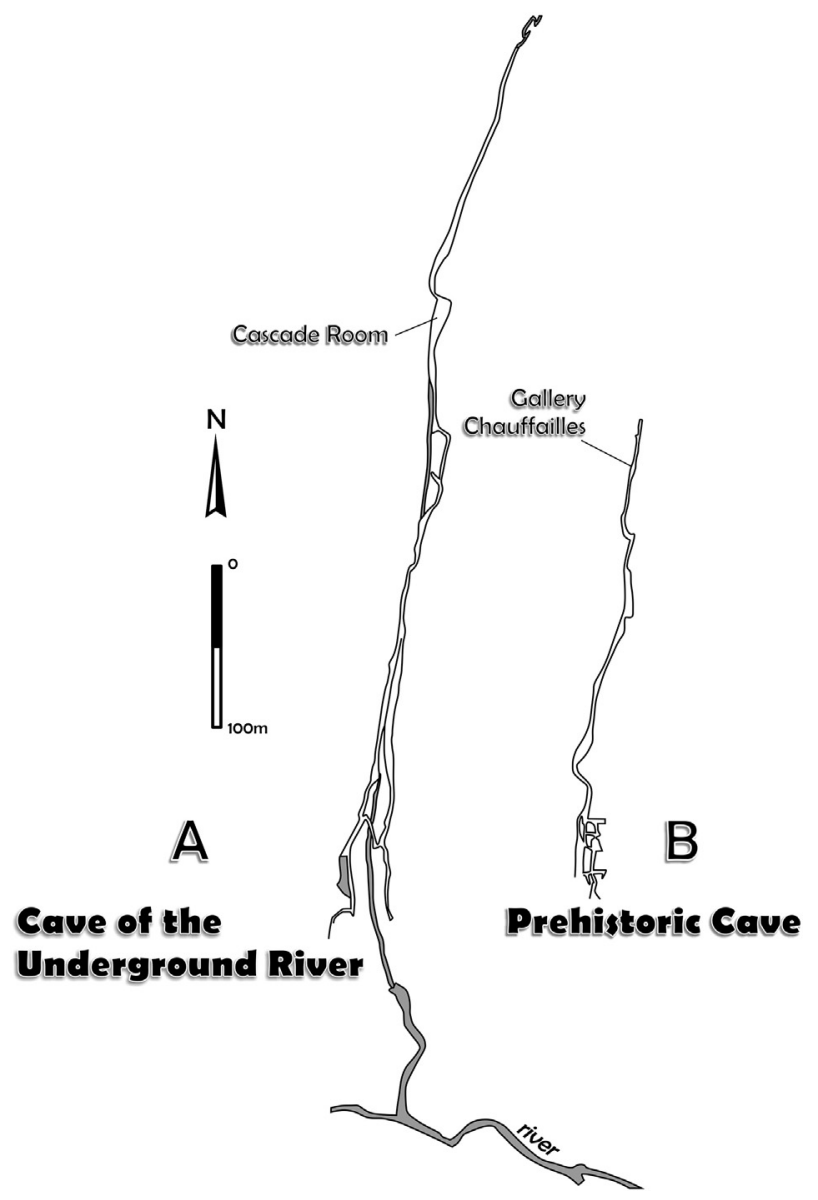

Fig. 31. Maps of the two karst networks that together comprise Azé Cave: (A) Cave of the Underground River; (B) Prehistoric Cave. 
nearly uninterrupted stratigraphic sequence spans from the AalenianBajocian to the Kimmeridgian (Fig. 35). The Upper Cretaceous is separated from the Lower Cretaceous by a major gap of 45 Myr during which the region developed under continental conditions. This period was conducive to deep weathering of the carbonate platform.

The main ghost-rock features in this region are seen in several quarries. In the quarry of Peusec, near the Touvre Springs, it is possible to see many of the morphologies associated with ghost-palaeokarsts as well as their relationship to features found at the surface. It can be seen, in the exposed quarry faces, that the lower bedding plane of the Kimmeridgian limestone is deeply weathered (Fig. 36). These ghost-palaeokarsts represent a residual soil, now without its original texture and fabric, which resulted from in situ weathering. This palaeosol is mixed with allochthonous alluvial white sandy layers and thick dark clayey deposits. There are a number of vertical weathered corridors that cross the whole Kimmeridgian series while other weathered galleries and ghost-endokarst have also been observed in the quarry (Fig. 36). These present typical gallery morphologies, including cupolas and lateral benches, and they are partially filled by dark clayey flow deposits containing subrounded blocks of weathered limestone mixed with thin silt and glauconitic sandy layers dating from the Early Cenomanian.

It is typical for the speleological networks in this region to be represented by maze caves. Several studies have investigated the relationship between ghost-rock features and speleological caves. The cave of La Fuie is situated near Chasseneuil in the northeastern part of the karst area of La Rochefoucauld. It has developed laterally for over a kilometre into the Bajocian dolomitic limestone with chert nodules (Fig. 37). The main drain is represented by the Galleries of the Ammonites and Belemnites, less than $10 \mathrm{~m}$ below the surface, in the epiphreatic zone. A number of morphological observations have indicated progressive weathering of the walls from a slightly weathered rock (a creeping rock that forms

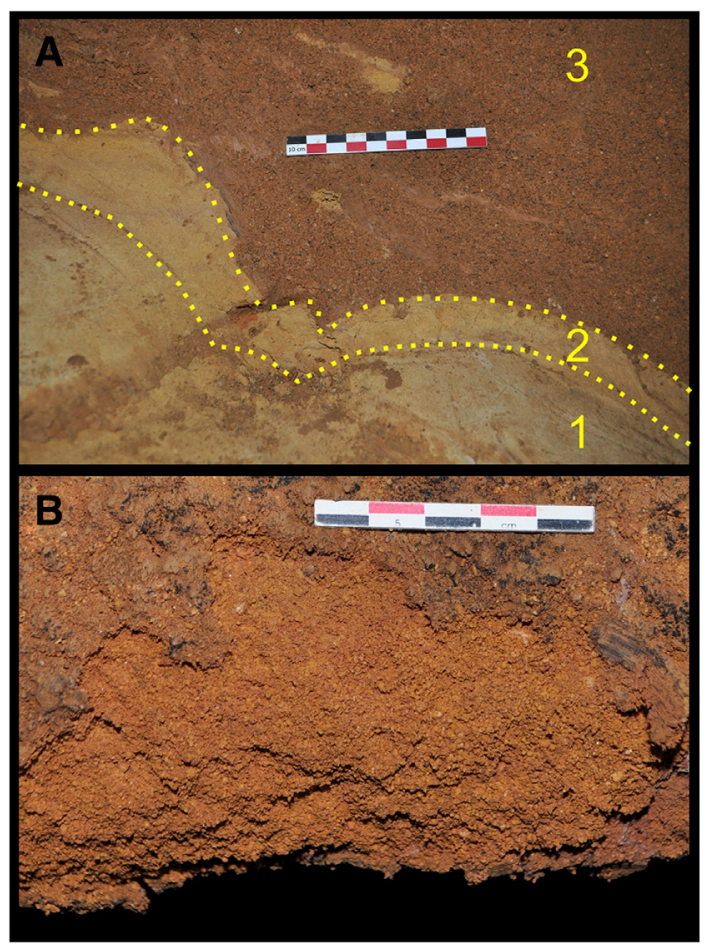

Fig. 32. (A) The Prehistoric Cave in the karst system of Azé: at the entrance to Chauffailles Gallery it is possible to observe contacts between a weathered rock with mechanical strength (1), a weathered rock with no mechanical strength (2), and Quaternary sediments in which the alterite can be seen as whitish lamina (3). (B) The Cave of the Underground River in the karst system of Azé: to the north of the Cascade Room it is possible to observe completely weathered limestone which can be easily disintegrated by hand.

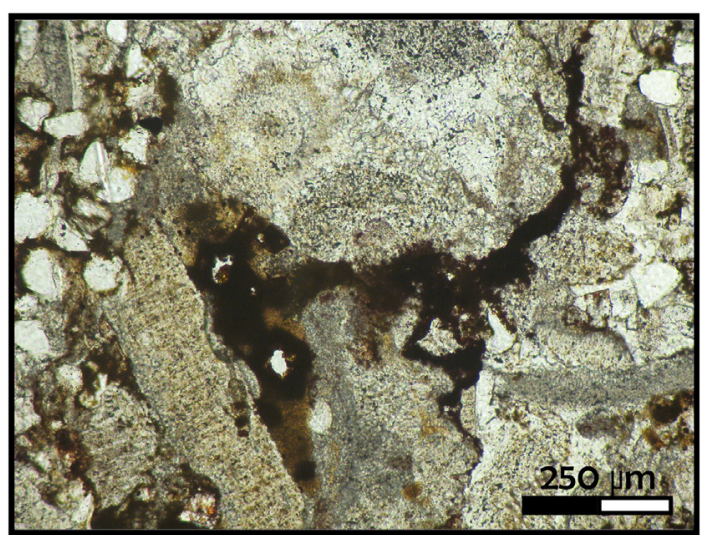

Fig. 33. Thin-section of the weathered limestone obtained to the north of the Cascade Room in the Cave of the Underground River. It shows quartz grains partially enclosed by iron bacterial and manganese bacterial filaments and clumps.

Photograph: R. Maire

microgours and micropipes with widths of less than $2 \mathrm{~mm}$ ), to a highly weathered rock with interbedded planes, and onto completely weathered rock steps with ascending collapse chimneys. The chert beds pass from the fresh rock into the alterite without interruption while it is also frequently possible to trace other geological features from unweathered to weathered limestone (e.g. calcite and ferromanganese veins, chalcedony geodes, and belemnite rostra fossils). A piezometer in the Gallery of the Belemnites has shown that the karst water table is characterised by high amplitude fluctuations. This fact, combined with evidence obtained during studies of the ascending collapse chimney and ghost-rock features, demonstrates that it is possible to excavate the residual alterite through the repeated flooding/dewatering of galleries in a cave system.

The speleogenesis of La Fuie Cave can be summarised in three chronological steps (Dandurand, 2011). The first phase is represented by the weathering of horizontal and vertical discontinuities which occurred during the $45 \mathrm{Myr}$ period of emergence that began in the Early Cretaceous. It is thought that the alterite was not removed at that time

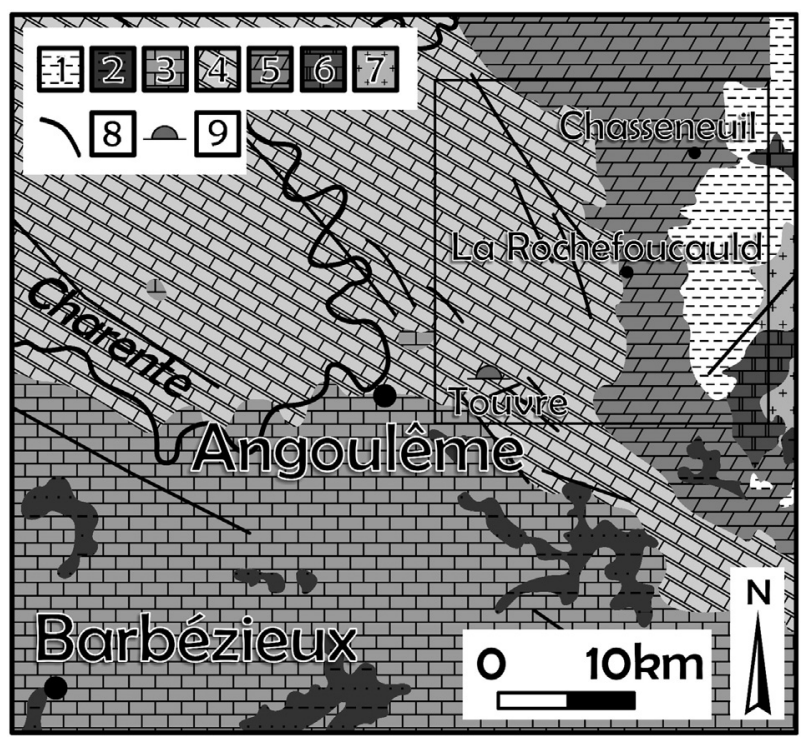

Fig. 34. A simplified geological map of Charente in western France: 1 - Neogene; 2 Palaeogene; 3 - Late Cretaceous; 4 - Late Jurassic; 5 - Middle Jurassic; 6 - Early Jurassic; 7 - Devonian; 8 - Main faults; 9 - Touvre Springs.

Constructed using data from IGN and BRGM. 
because of the negligible hydraulic gradient associated with the lowlying carbonate platform. The second phase is represented by partial removal of the alterite due to a higher hydraulic potential that enabled transport of weathered particles. It is thought that this process corresponds to a particular type of regressive erosion in which the internal water passes slowly through the porous ghost-rock feature and gradually excavates the carbonate particles. This stage is linked to erosion of Cenozoic overburden in the Early Pleistocene caused by uplift of the Massif Central. At this time the Galleries of the Ammonites and Belemnites become the most important drainage channels and removal of alterite was promoted by the high karst water table fluctuations. Moreover, dewatering may also have been influenced by the opening of a hydrological window, the Valley of the Bonnieure, causing a lowering of the local groundwater level. The third stage is represented by the mechanical erosion that occurs when the ghost-rock features pass from the phreatic zone into the vadose zone. It is thought that the ascending collapse chimneys formed during this stage, which is ongoing at present.

In total twelve samples have been analysed from Peusec Quarry. The petrophysical analyses show a progressive weathering gradient from slightly weathered rock near the edge of a gallery in the quarry face to completely weathered rock at the centre of the feature. The fresh and slightly weathered samples are characterised by densities of about $2.65 \mathrm{~g} / \mathrm{cm}^{3}$, average porosities of about $15 \pm 0.5 \%$, and the material is composed entirely of carbonate (100\%). At the centre of the feature the density is reduced to $<2 \mathrm{~g} / \mathrm{cm}^{3}$, the porosity is increased by about $40 \%$, and the $\mathrm{CaCO}_{3}$ mass content drops drastically to less than $60 \%$. From the study of thin-sections it is seen that the increase in porosity initially results from dissolution of the inter-oolite sparitic and microsparitic structures before progressing to the micritic oolites.

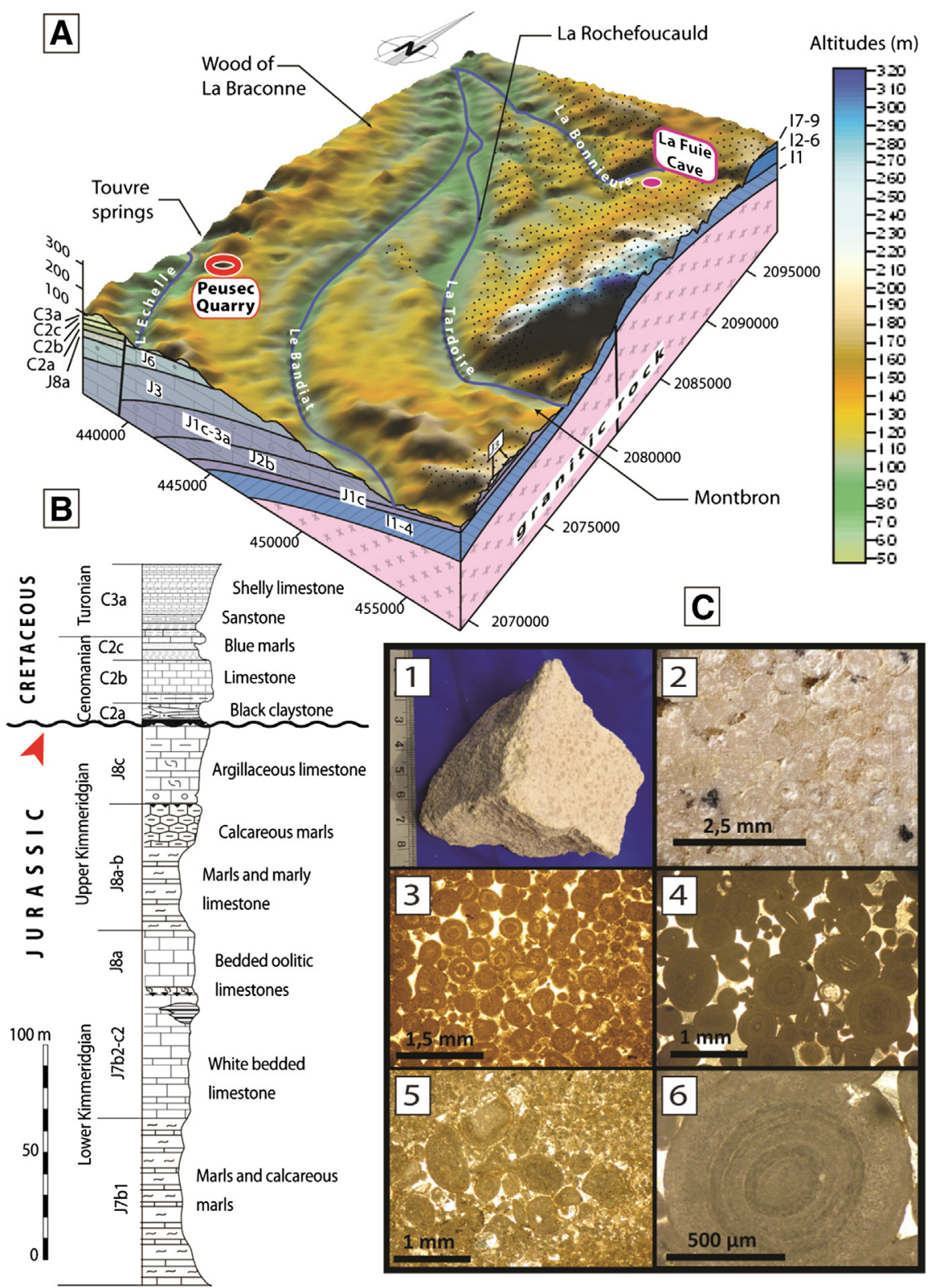

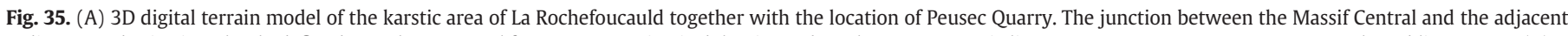

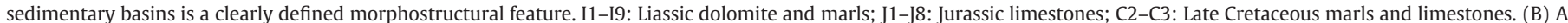

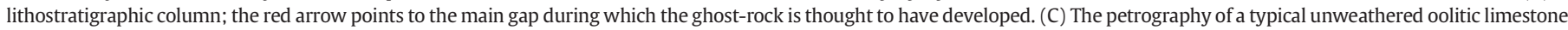

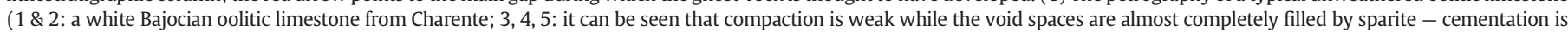
possibly at an early-stage; 6 : the structure of an individual oolite). 
There are also concentrations of iron oxides on the edges of oolites and sometimes even within the oolites themselves (Fig. 38). The origin of this ferruginisation is not yet clear although, as bacterial activity appears to be conducive to oxidation, bacteria may well play a role in the formation of ferric microspheres on, in particular, the edges of the oolites.

\subsubsection{The Jurassic limestone and dolomite of Les Grands Causses}

The Grands Causses are located in the southern part of the Massif Central (Fig. 39). Its bedrock is dominated by Jurassic limestone and dolomite while the landscape is characterised by huge limestone plateaux cut by deep canyons. At the end of the late Jurassic the sea retreated and this area was affected by the first stages of karstification as represented by bauxite formations and also some karst morphologies such as poljes. These landscapes were fossilised during the Upper Cretaceous transgression which covered the entire southern margin of the Massif Central. The tectonic framework of the region during the Cenozoic resulted from Pyrenean uplift in the Eocene. However, from the Oligocene to the beginning of the Miocene, a succession of flat karst surfaces developed in association with the poljes. From the beginning of the Miocene, due to uplift of the Massif Central, the Jurassic platform has been dissected by incising rivers and the plateaux have become increasingly isolated. The higher hydrogeological gradient leads to the partial destruction of flat morphologies and the emptying of ghost-endokarst. These processes are continuing at present as illustrated by karst drainage reorganisation, the stripping of surficial deposits, and excavation of the karst systems.

This area is characterised by several types of ghost-rock feature which have developed in two different formations (Bruxelles, 2001). First, the Bajocian limestones and dolomites with cherts appear mainly at the edge of the plateaux or along major faults. This formation is deeply decomposed and has innumerable pockets of clay or sand with cherts (Fig. 40). The calcite has been dissolved to leave siliceous pockets partially filled with neogenetic smectites. These pockets can be distinguished from cryptokarst due to the fact that it is possible to recognise chert horizons, warped due to post-dissolution compaction, running through the alterite (Fig. 41). The clays with flints that result from this weathering are very important in the subsequent development of the karst topography. From the edges of the plateaux, the clays with flints are reworked toward the central parts, where they constitute a thick cover - many karst features including cryptocorrosion surfaces, corrosion borders, and poljes have developed as a result of this clayey cover. Second, the Bathonian dolomite outcrops over a very large part of the Grands Causses. This has a thickness of about $150 \mathrm{~m}$ and most of its discontinuities are weathered from the surface to the base of the formation. These weathered faults, cracks, and joints create a network of high corridors filled with dolomitic sand - this sand comprises dolomitic rhombohedra while only the calcitic cement has been removed by dissolution. However, following a drop in base level, surface erosion is
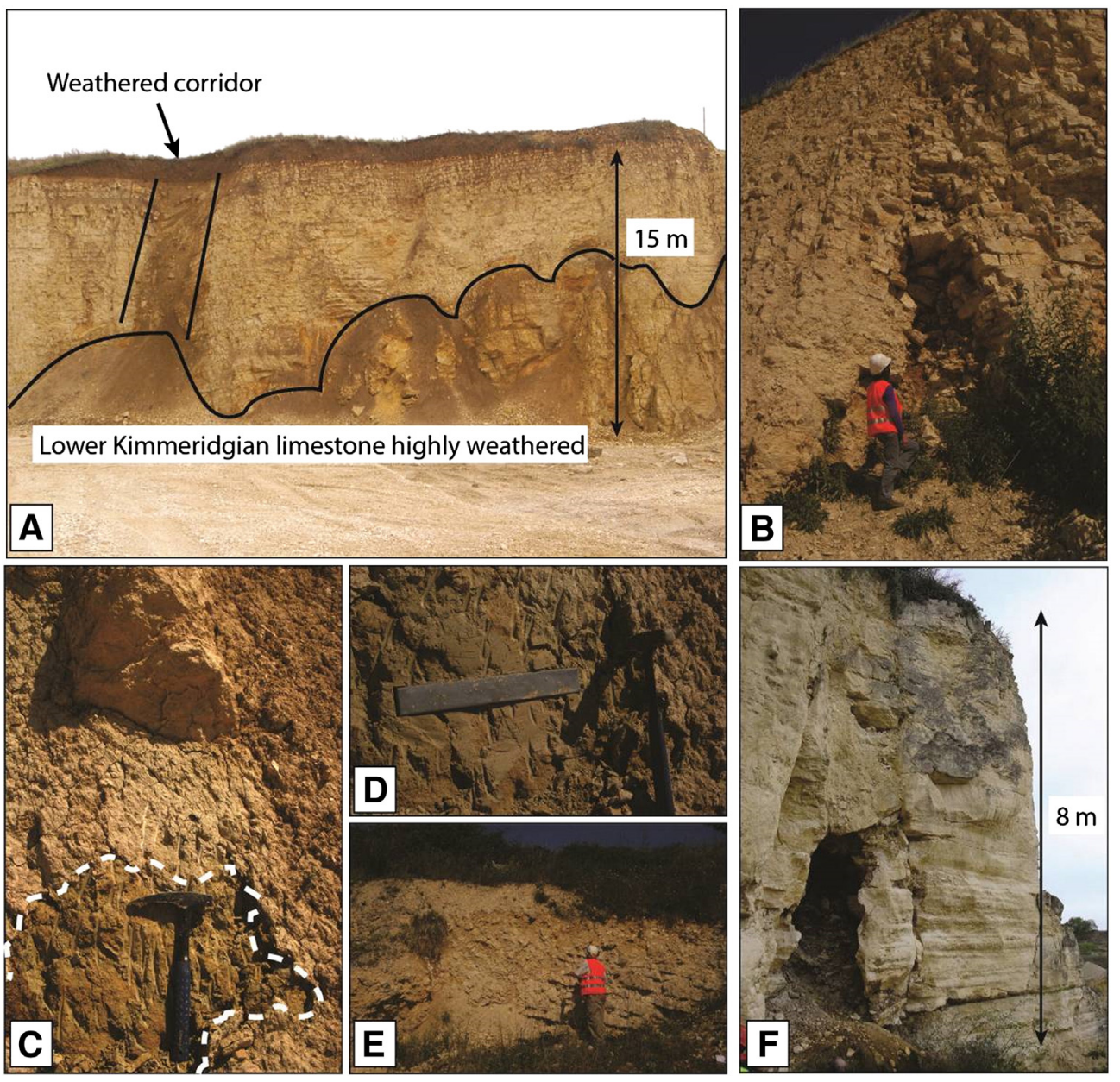

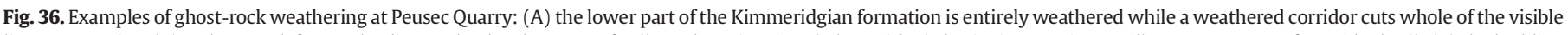

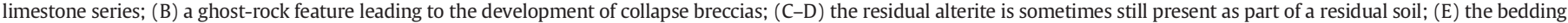

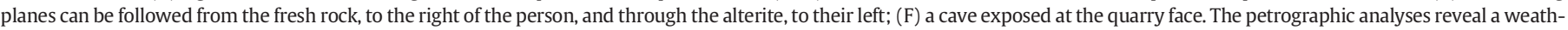

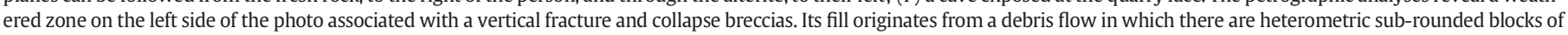
porous limestone and, at lower levels, fine glauconitic sandy loam assigned to the Cenomanian. 
able to remove the sand easily leaving a series of dolomitic pinnacles with heights of up to $30 \mathrm{~m}$ - these are mega-lapiaz and they constitute the most famous characteristic landforms in the Grands Causses (Fig. 41). The removal of this alterite leads to the development of underground rivers, pits, and speleological caves. It is an ongoing active process and it is known that huge amounts of dolomitic sand are excavated during each flood event.

While the formation of ghost-rock has had an important impact on the development of the karst landscape of the Grands Causses, it also plays a major role in defining the location and organisation of the karst aquifers. The local geological history suggests that ghost-rock was able to develop from the end of the Jurassic to the beginning of the Miocene due to the fact that there was an insufficient hydrogeological gradient to remove the alterite during this long period. However, as soon as canyon dissection enabled the development a number of powerful karst springs, the alterite began to be removed. Headward erosion in the weathered limestones and dolomites exported the dolomitic sand and emptied the highest discontinuities. In this way, the
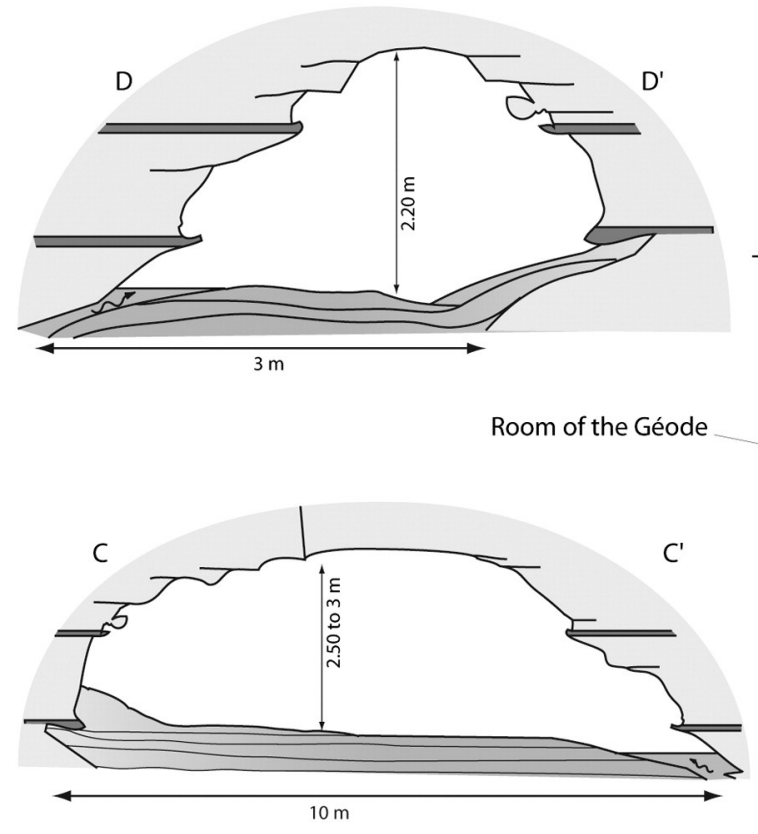

$-8$
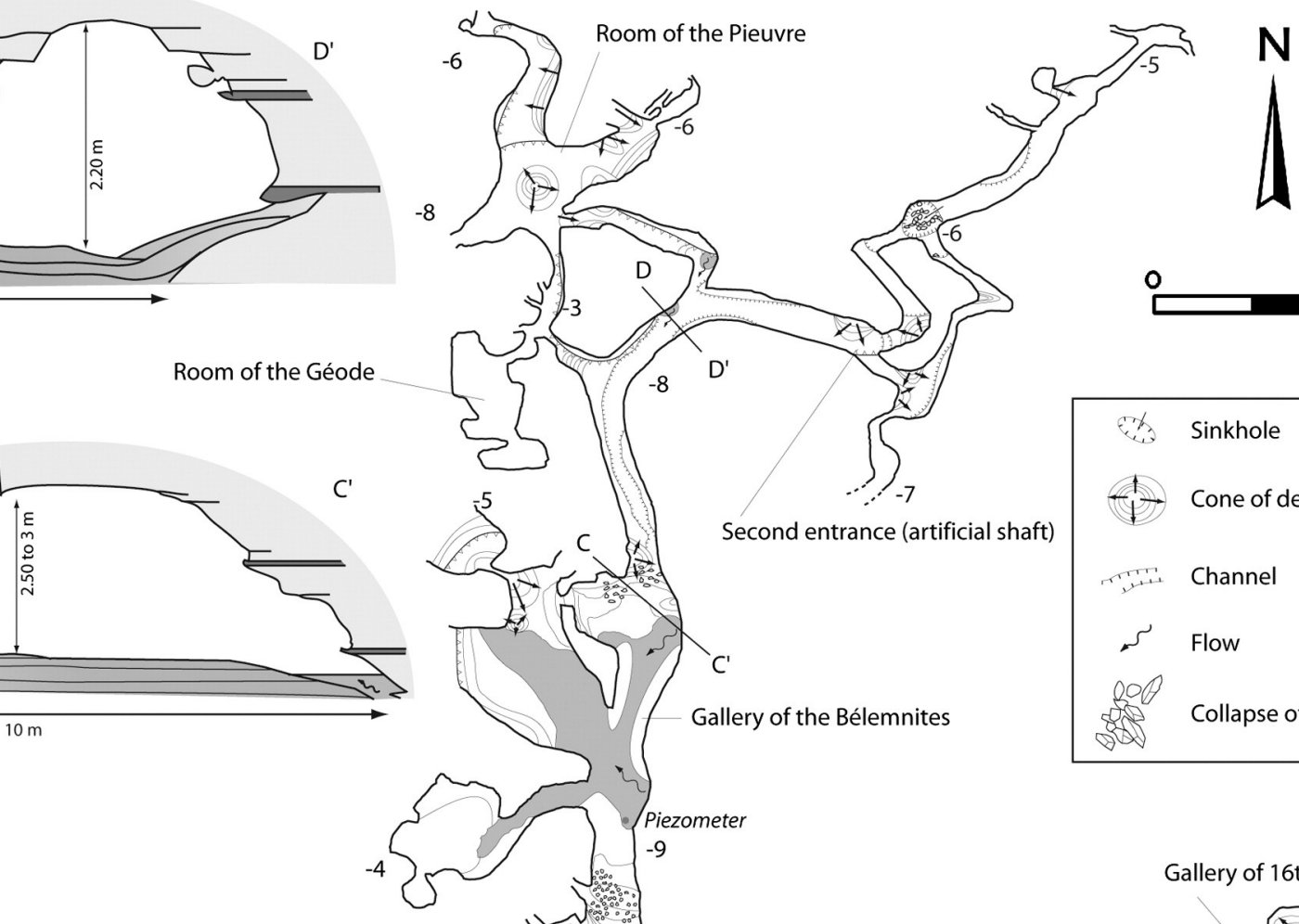

D'

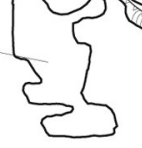
$5,-3$ D

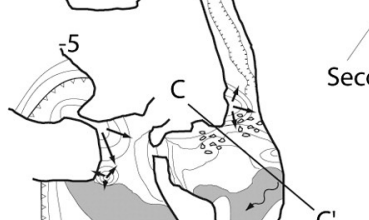

Second entrance (artificial shaft)
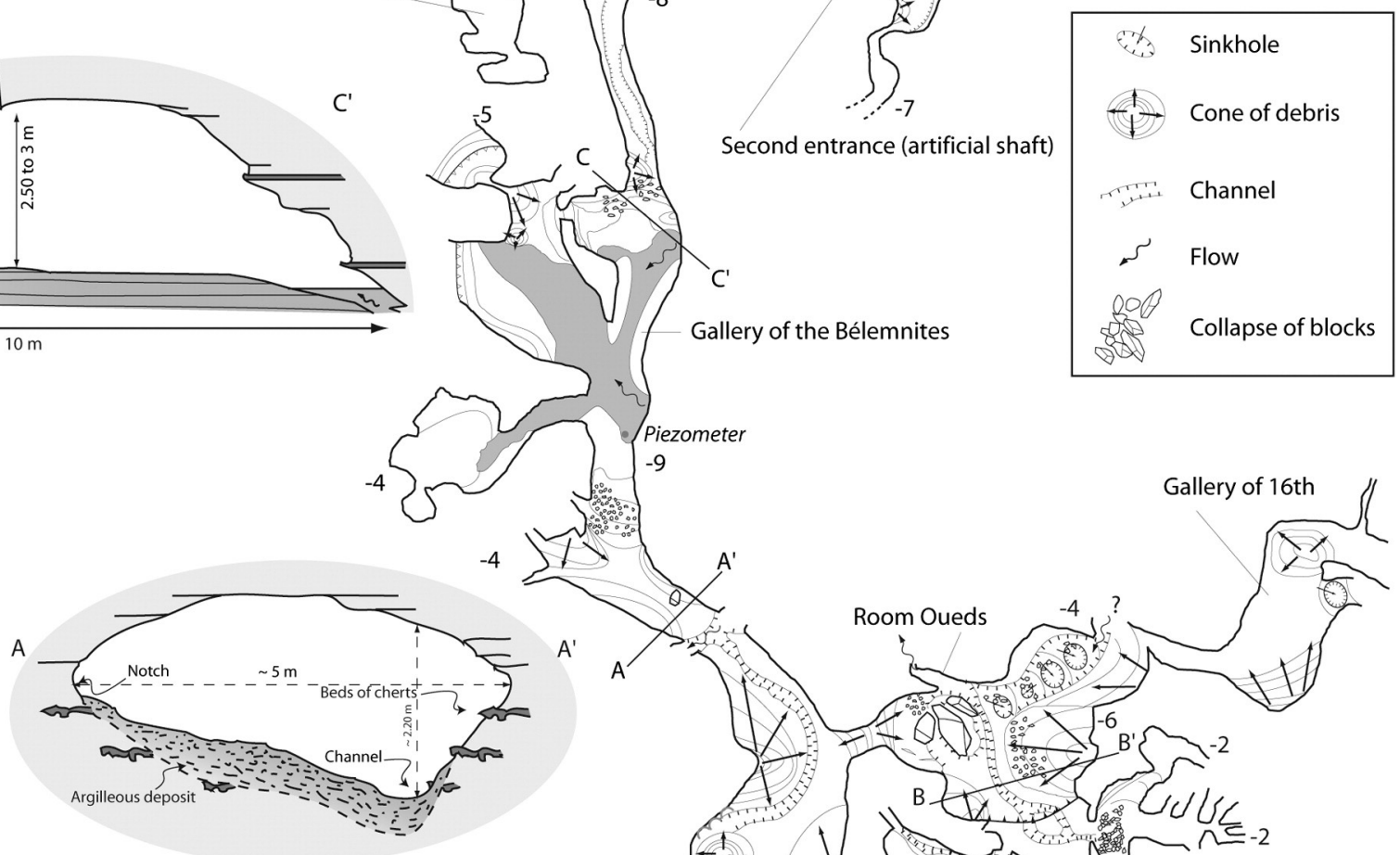

First entrance
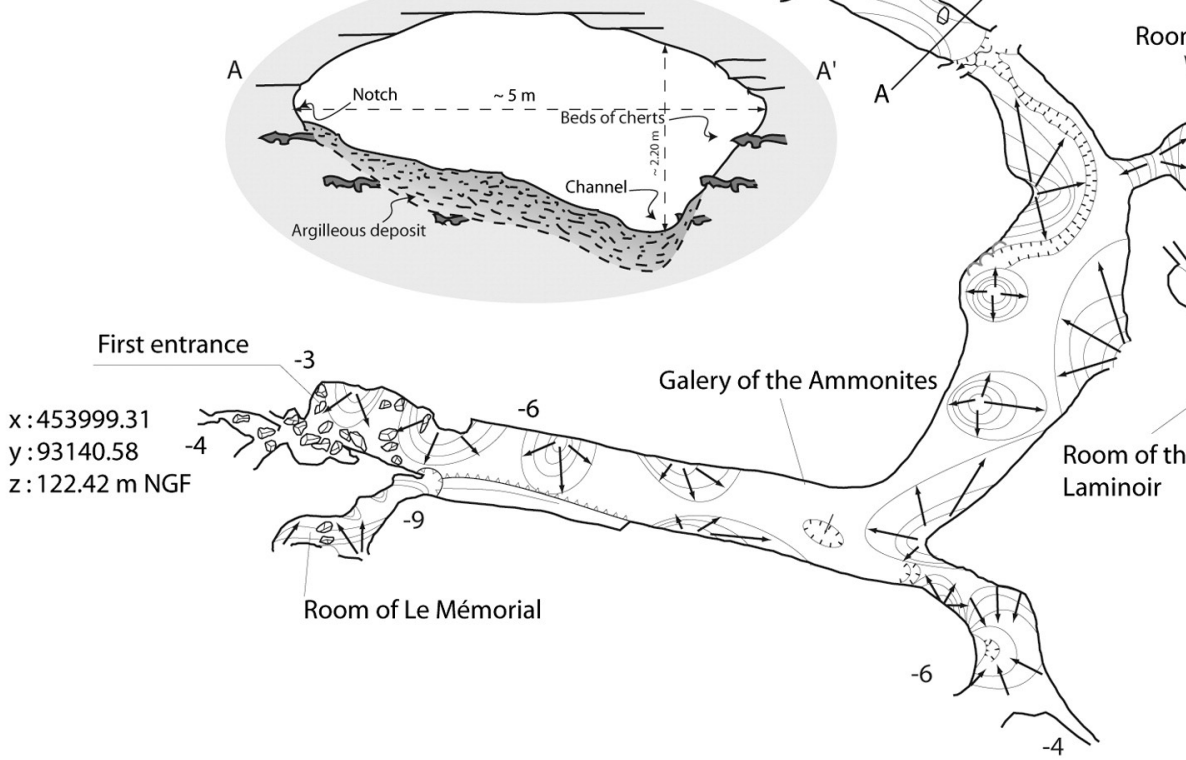

Room Oued
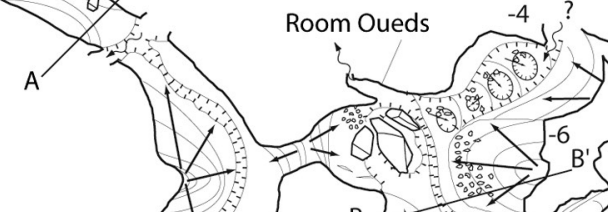

Gallery of 16th
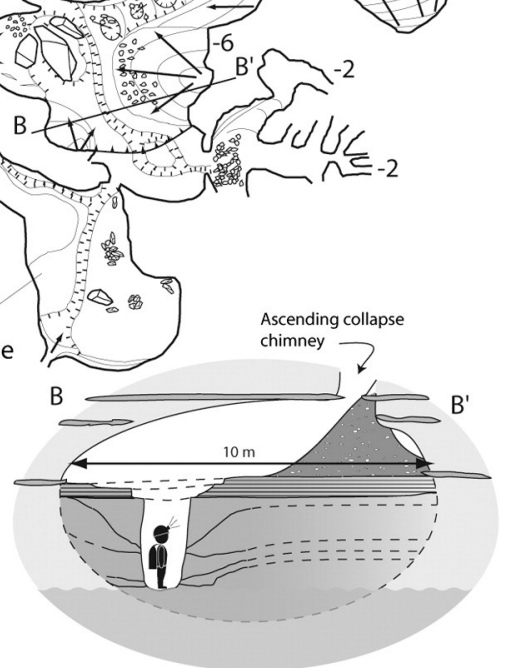

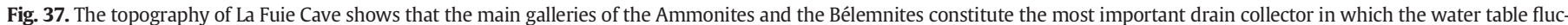

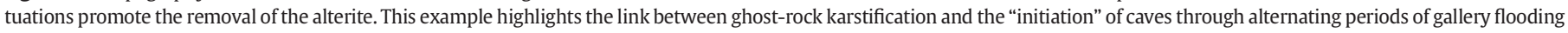
and dewatering.

Mapping by P. Bussard, J.-M Devesnes, D. Doucet, C. Dupré, F. Versaveau, G. Fersing and G. Dandurand. 
catchment areas of the springs grew rapidly within the plateau while, at the surface, many sinkholes appeared as a consequence of alterite excavation by underground streams. It is common to find new sinkholes regularly appearing while the largest springs, benefiting from favourable geological structure and close connection to a ghost-rock network, often capture the catchment areas of their adjacent springs (Bruxelles, 2001).

\subsubsection{The Cenomanian chalky limestone of Normandy}

The hills of Perche in the south of Normandy, near the eastern margin of the Armorican Massif, represent the interfluve separating the catchments of the Seine and Loire Rivers. Its Cretaceous bedrock is dominated by chalky limestone from Lower and Middle Cenomanian, overlain by an almost always impermeable clay-sand formation, the Upper Cenomanian 'Sands of the Perche'. In the north, a long glacis extending across the Sands of the Perche has promoted the development of a dense network of streams that feed the tributaries of the Seine. In the south, around the Huisne River in the Loire Basin, the surface drainage is associated with a large depression in the Cenomanian cover which follows the edge of a cuesta. In this region there are a number of quarries that intersect the karstified tectonic axis. The most notable site is the Mansonnière in Bellou sur Huisne, Orne, which has developed beneath a plateau between two meridian dextral strike-slip faults at around $150 \mathrm{~m}$ asl (Fig. 42). This has generated an extremely tight cluster of faults that extends and connects discontinuities to form a plurimetric meshed network which fully incorporates the karst maze. More than $1000 \mathrm{~m}$ of natural corridors, almost entirely filled with chalky sand and particularly fine swelling clays (smectite), have been investigated after digging (Fig. 43). This network is found a few metres below the surface in a freestone facies known as the 'Chalk of Rouen'. The surrounding rock presents a very thin layer of weathered clayey limestone with a thickness of less than $0.20 \mathrm{~m}$ (Rodet, 1996).

From studying the loose material in these galleries it is known that: (1) vertical bedding dominates and this is characteristically almost symmetrical around a near vertical clayey centreline that represents the initial discontinuity from which the weathered feature has developed; and (2) there is an absence of horizontal sedimentation resulting from flow processes. Therefore, since their formation, these features have not hosted fluvial drainage. Furthermore, geochemical analyses (Table 1) show that the mineral composition is very monotonous and that the unconsolidated material is derived entirely from the host rock (Rodet, 2014). These features result from chemical weathering processes in which water from the surface infiltrates along the discontinuities until

A
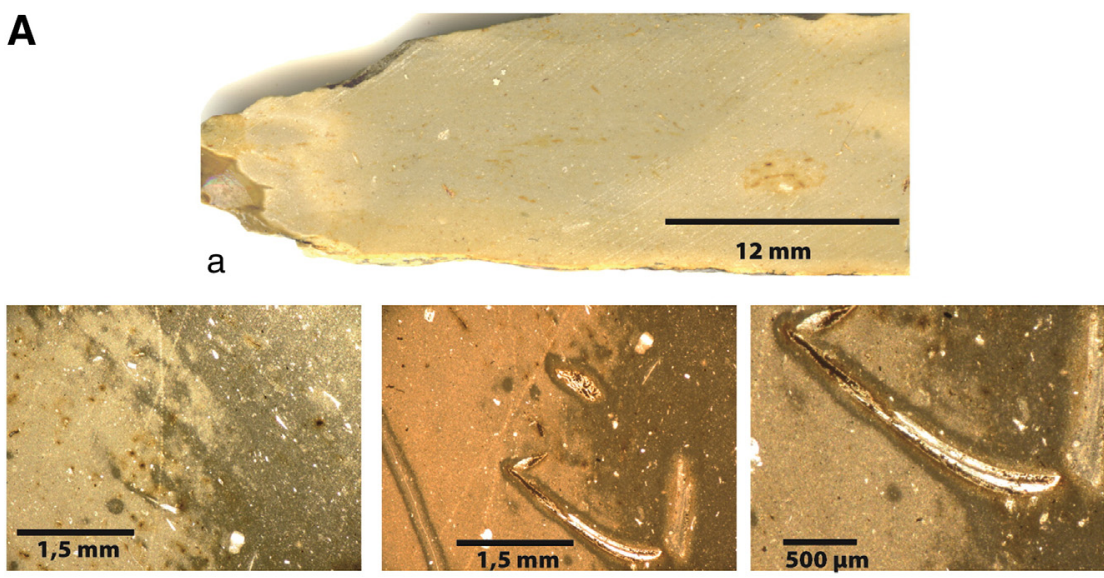

b- («LN»)

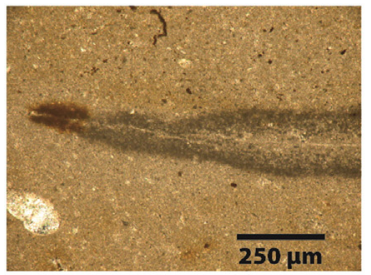

e - («LN»)

B

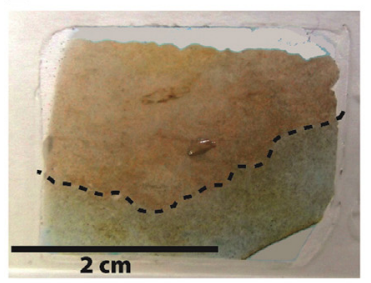

h
C- («LN»)

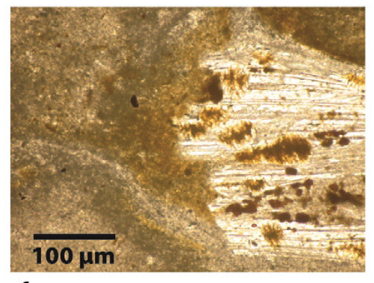

f- («LP»)

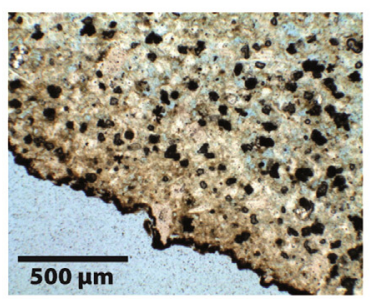

i- («LN») d- («LN»)

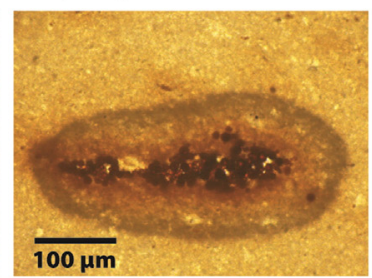

g- («LN»)

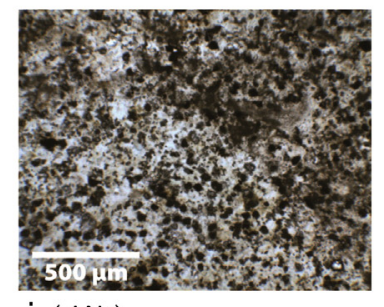

$\mathrm{j}-($-LN»)

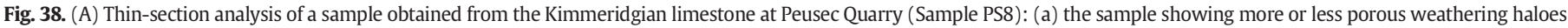

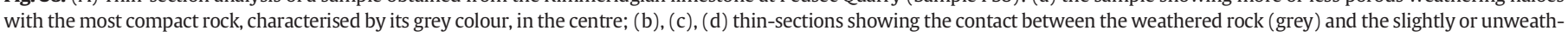

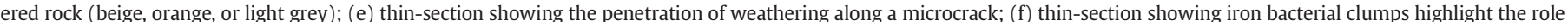

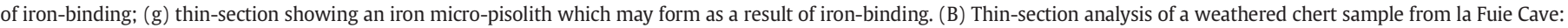

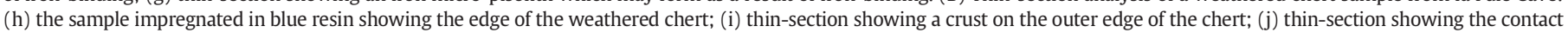
between the weathered rock (darker area - higher porosity) and slightly weathered rock (lighter area - lower porosity). 
it encounters a stratigraphic or piezometric obstacle. The percolating water is also diffused horizontally thereby expanding the lateral influence of the weathering (Rodet, 2003). The weathered features vary greatly in width from a few centimetres to as much as 6 m over very short distances $(>1 \mathrm{~m})$. The wider areas reflect points at which different weathering features intersect and coalesce. It, therefore, appears that the width a specific weathered feature directly reflects the amount of water that is able to infiltrates into it (Fig. 44). In the context of progressive weathering of the bedrock this example corresponds to a late stage of weathering during which the weathering is not simply confined to tectonic joints but can also develop locally along bedding planes. In the terminology of chalk weathering, these features are 'primoforms' from an 'introduction karst', in which no connection has yet been made between the input and output of the system (Rodet, 2002).

\subsection{Italy}

\subsubsection{The Liassic silico-clay limestone of Lombardy}

Monte Bisbino is located along the western side of the western branch of Lake Como and represents the last mountain to the south of the Italian Alpine foothills (Fig. 45). The western side of the lake is entirely composed of Moltrasio limestone from the Lower Lias and this is a well stratified dark grey limestone with flint nodules or beds interbedded with clays and marls. The $\mathrm{CaCO}_{3}$ content of the limestone varies from $45 \%$ to $60 \%$ while the remainder is dominated by silica from sponge spicules. From a structural perspective the area is almost monoclinal with dips to the W-SW. It has been affected by strong brittle deformation and eight fracture systems can be recognised - the main ones are oriented E-W, N-S, and NE-SW. Many of these fractures were reactivated as normal faults during the Cenozoic, especially those orientated $\mathrm{N}-\mathrm{S}$, sometimes accompanied by an E-W strike-slip component. The process of ghost-rock karstification systematically affects the N-S and E-W vertical joints and this has generated a lattice network of weathered discontinuities (Tognini, 1999a,b). These discontinuities guide the spatial distribution of subterranean cave galleries as well as ghost-rock features at the surface. The N-S system is very dense but mainly comprises short fractures while those of the E-W system are usually longer. As a result the N-S system is associated with widespread short shallow ghost-rock features while the E-W system is associated with far longer features.

The surficial weathering forms are represented by corridors that can attain depths of more than $10 \mathrm{~m}$ and which are organised as an orthogonal network with constant spacing (Fig. 46). The precise nature of the rectangular pinnacles and towers depends upon the extent to which the alterite has been removed. It is possible to find local screes composed of rectangular blocks that, from a conceptual point of view, are identical to those that result from the arenisation of granite (Fig. 47). Furthermore, these fractures are slowly forced open by gravitational slope deformations so that slope processes are, in turn, partly responsible for enlarging the weathered joints and excavating the alterite. The presence of deeply weathered fractures, exhibiting unstable mechanical behaviour, has clearly conditioned the distribution and geometry of deep seated gravitational slope deformations. These phenomena are interconnected and each has the ability to enhance the other. Instances of ghost-rock karstification are evenly distributed from the top of Monte Bisbino at $1325 \mathrm{~m}$ asl down to almost $600 \mathrm{~m}$ asl. The spatial distribution of the weathered network suggests that the weathering process becomes increasingly ineffectual with depth from the surface.

The excavation of subterranean ghost-rock features by mechanical erosion has created a number of karst systems. There are twenty five known caves on Monte Bisbino, of which the main ones are: Buco della Volpe, Grotta dell'Alpe Madrona, and Zocca d'Ass (Fig. 48) (Bini and Cappa, 1977). Despite the fact that the karst potential exceeds $1100 \mathrm{~m}$ there are only a small number of caves below the limit of ghost-rock karstification. It is clear that karst is strictly linked to the process of ghost-rock karstification. The cave morphologies are characterised by: (1) a lattice network of galleries that often intersect at right angles; (2) galleries whose walls are made of alterite and exhibit diverse cross-sectional forms (i.e. sub-circular, elliptical, and rectangular); (3) irregular galleries with -forms, -forms, +-forms, or L-forms developed at the intersection of several ghost-rock features; (4) disconnected shallow-holes; and (5) galleries terminating in ending in deadends. These criteria are all symptomatic of galleries that result from the excavation of ghost-rock features.

It is known from microscopic analyses that the micritic limestone matrix disappears as a result of weathering and the new open pores

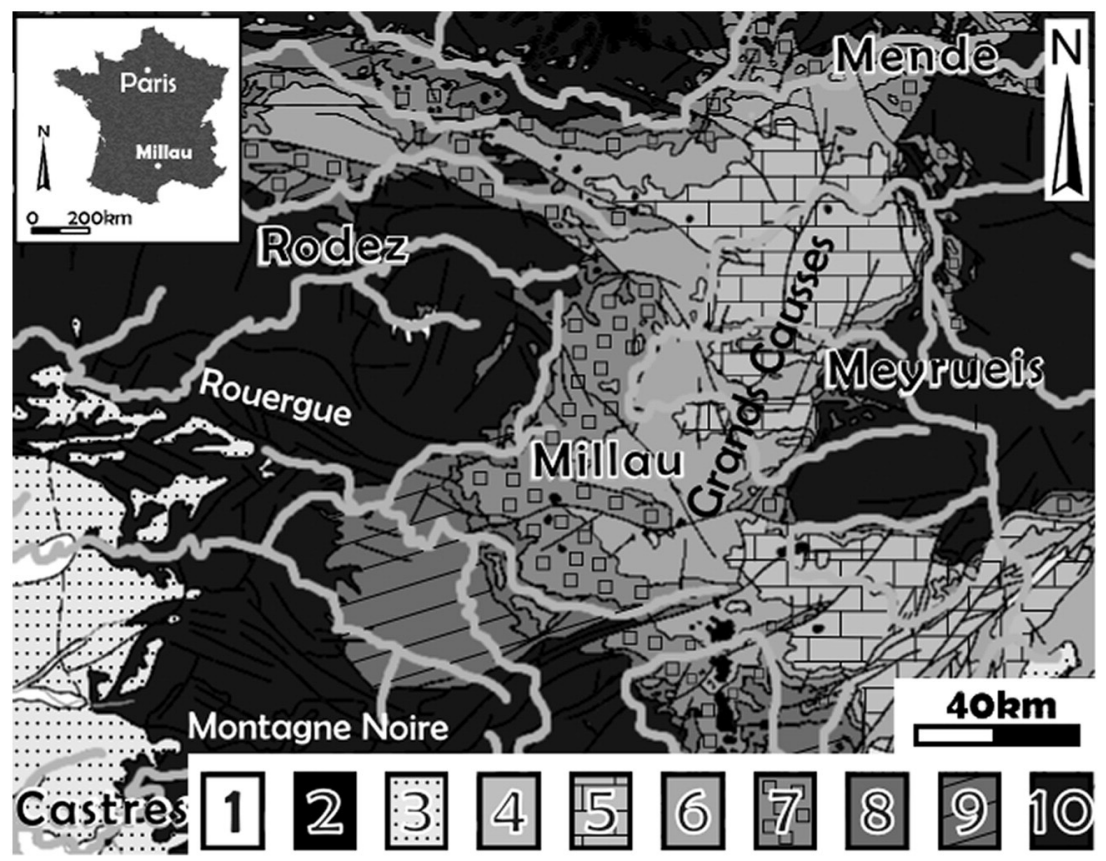

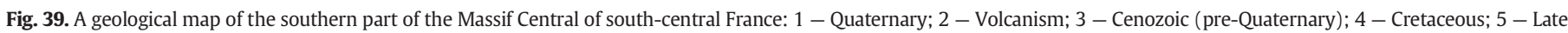
Jurassic; 6 - Middle Jurassic; 7 - Early Jurassic; 8 - Triassic; 9 - Permian; 10 - Palaeozoic basement. 


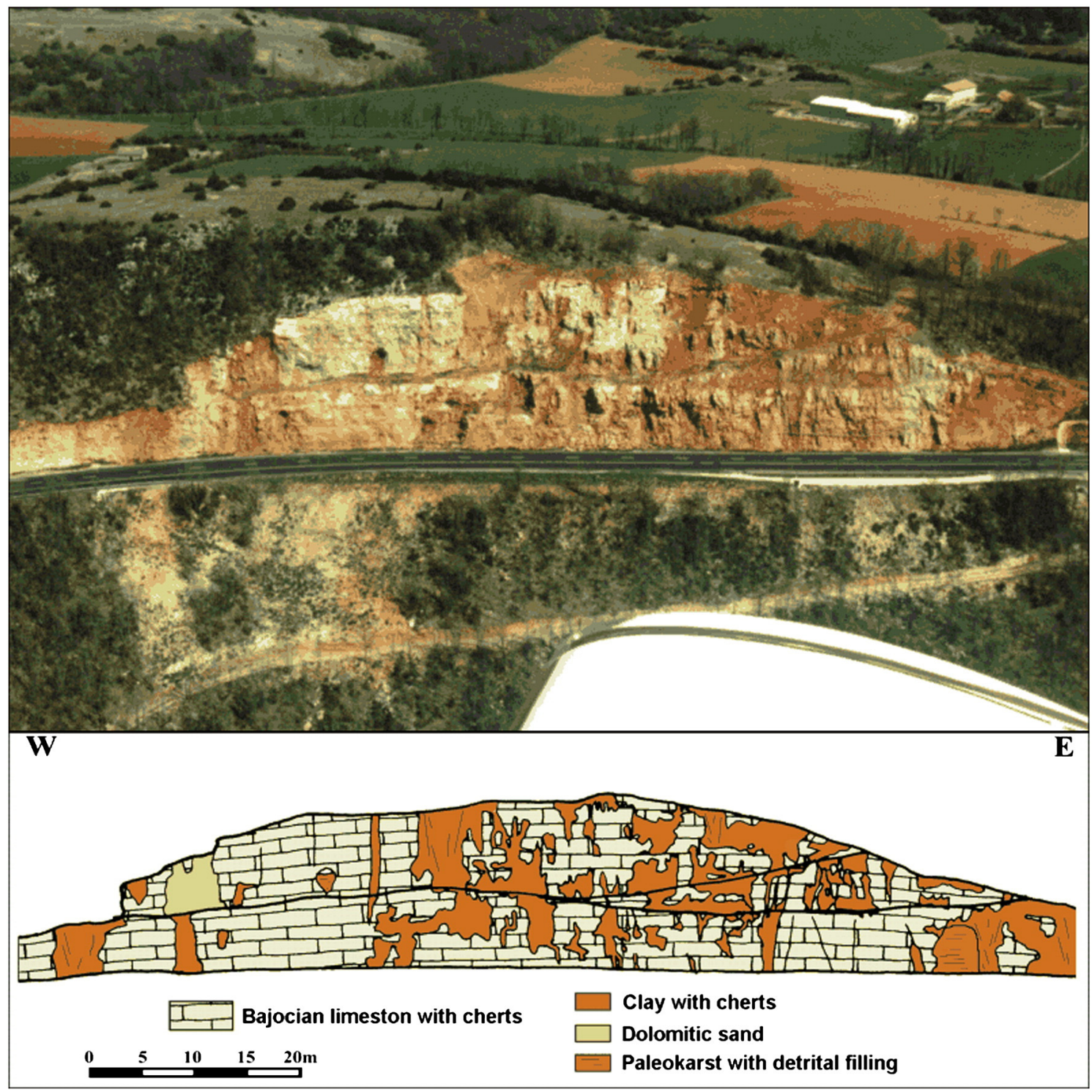

Fig. 40. A cutting along the D 999 road which demonstrates the high degree of weathering within the Bajocian Formation (limestones and dolomites with flint).

become partially filled with iron oxides and clays. The $\mathrm{CaCO}_{3}$ content decreases from around $60 \%$ to $45 \%$ in the fresh rock to around $7 \%$ to $0.5 \%$ in the completely weathered rock while SEM analysis shows dissolution marks on the sponge spicule silica as well as on quartz crystals filling the extension joints (Fig. 49). XRD analysis of the completely weathered rock indicates that the clay fraction below $<2 \mu \mathrm{m}$ comprises quartz. The weathering front is characterised by reddening and this is often emphasised by a very porous thin crust, with a thickness of no more than a few millimetres, rich in iron nodules, of around a millimetre, not found in the fresh rock. The process of ghost-rock karstification in the Moltrasio limestone results in the dissolution of the micritic calcite, partial dissolution of the silica, and increases the porosity of the rock.

\subsection{Great Britain}

\subsubsection{The Carboniferous limestone of southern Pembrokeshire}

Bullslaughter Bay is located along the coast of southern Pembrokeshire in southwest Wales (Rowberry et al., 2014) (Fig. 50). This area lies close to the northern limit of the strong Variscan deformation that affected Britain during the late Carboniferous. The Carboniferous limestone bedrock belongs to the Pembroke Limestone Group and crops out in three major synclines trending W-E: the St Florence, Pembroke, and Bullslaughter Bay Synclines. These folds are cut by two conjugate sets of later strike-slip faults striking NNW and NNE. The structural geology at Bullslaughter Bay is complicated: the bay is cut by the axis of the Bullslaughter Bay Syncline while in the eastern part of the bay a series of tight fold structures lie to the south of the main syncline. Furthermore, two large breccia masses are located at either end of the bay (Walsh et al., 2008). The cliffs are built predominately from the Oystermouth Formation, of Viséan age, which comprises thin to medium bedded dark grey argillaceous limestones and mudstones with chert nodules or beds (Waters et al., 2009). This formation is both unweathered and weathered. A comparatively small section of the cliffs are built from the mudstones and thin bedded radiolarian cherts of the Aberkenfig Formation, of Serpukhovian age, but this formation is not discussed here.

The Oystermouth Formation was deposited in shallow marine waters and it is characterised by numerous facies changes. In such a heterogeneous formation the specific characteristics of the unweathered rock determines the result of the weathering. The weathered rocks occur as wide weathered areas that extend down the entire cliff section 

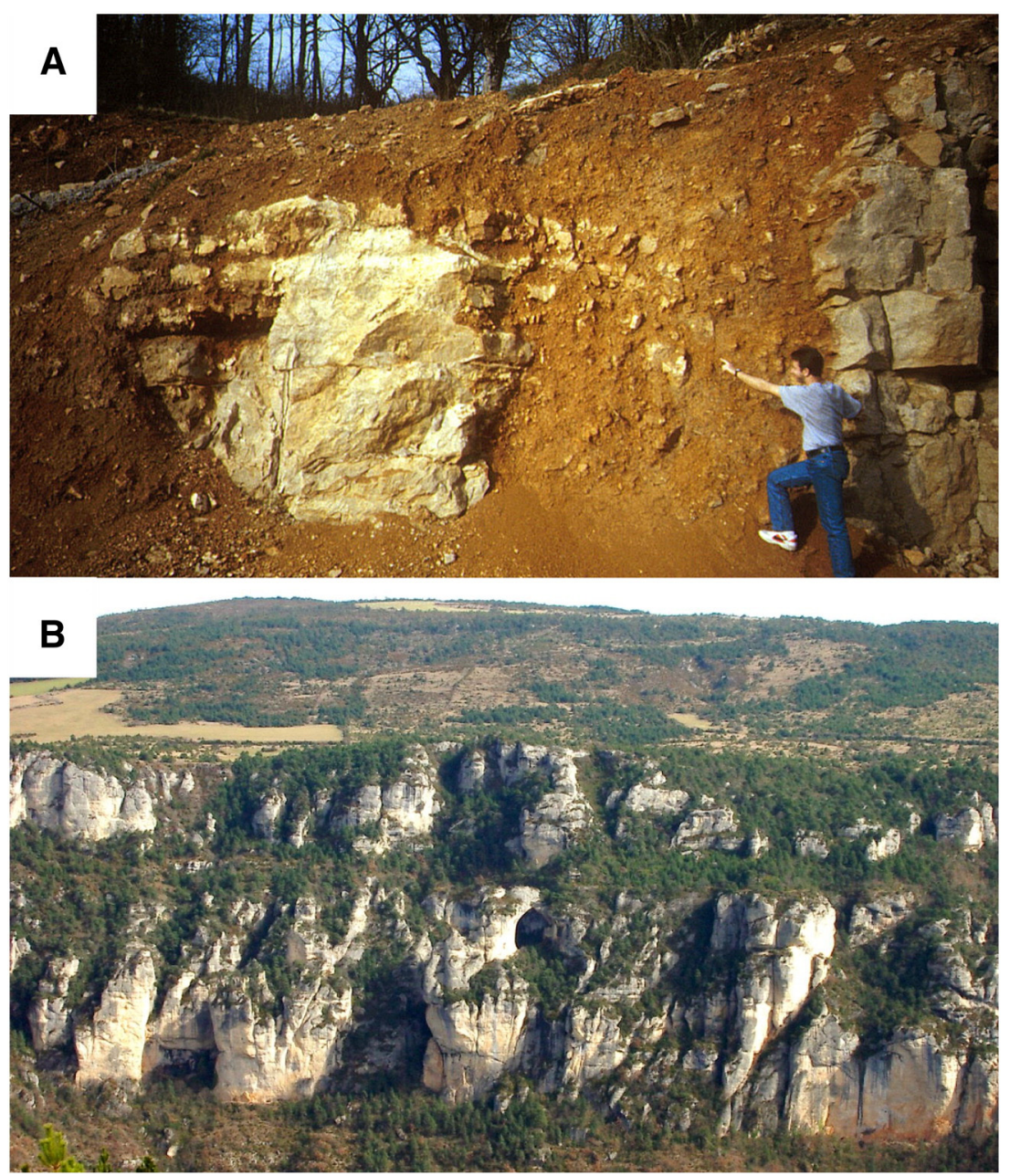

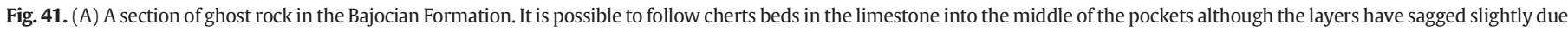

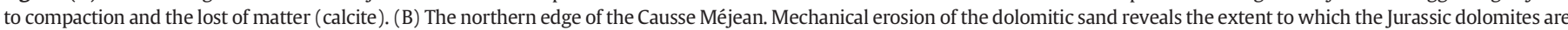
affected by deep weathering as it exhumes these tower-like mega-lapiaz.

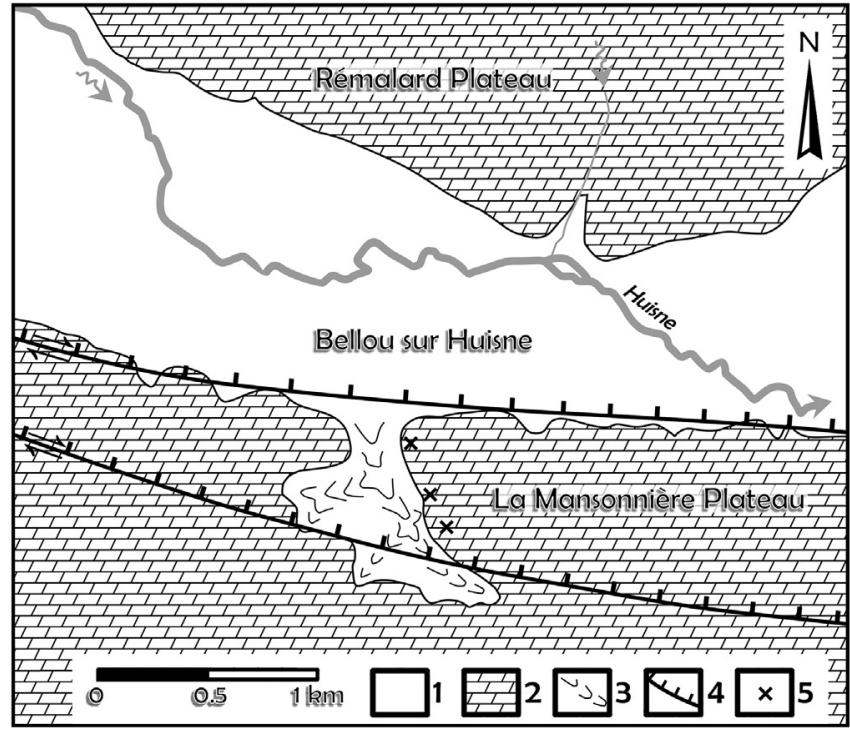

Fig. 42. A geological map showing the area around La Mansonnière: 1 - river terraces 2 - Cretaceous; 3 - thalwegs; 4 - faults; 5 - the location of caves and mines. The karst network has developed in one of these mines. while the weathering profiles are not characterised by vertical gradients (Fig. 51A-F). In some places the weathered limestone appears as isolated decalcified blocks while in others it appears as banded ochreous and slightly calcareous sands and silts. The banded sands and silts were previously thought to represent a sedimentary deposit but this interpretation does not take account of the fact that the isovolumetric nature of the weathering is readily recognisable. It is frequently possible to trace

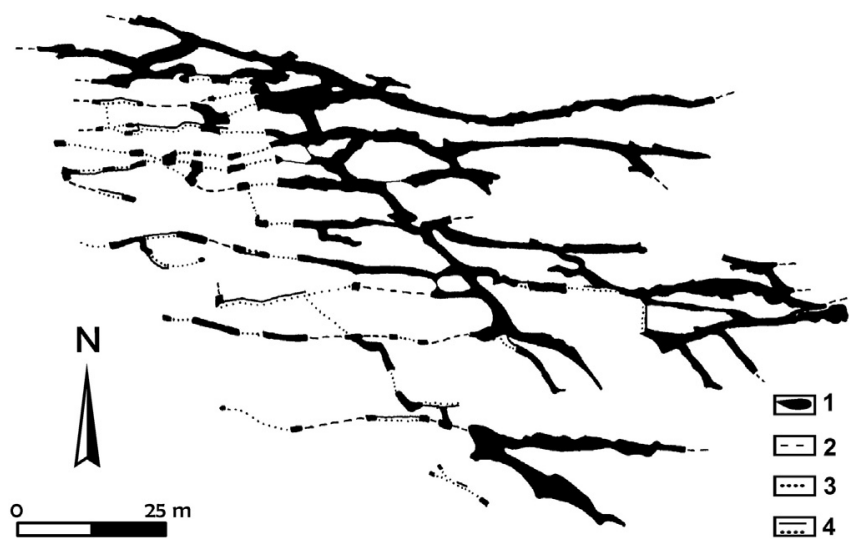

Fig. 43. The karst network of La Mansonnière: 1 - penetrable gallery; 2 - impenetrable gallery; 3 - gallery cut during mining; 4 - gallery drilled at the mine face. 
Table 1

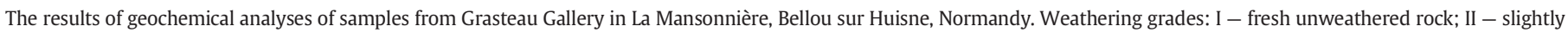
weathered rock; III - moderately weathered rock; IV - highly weathered rock; V - completely weathered rock. Analyses by A.-V. Walter, Besançon.

\begin{tabular}{|c|c|c|c|c|c|c|c|c|c|c|c|c|c|c|c|c|c|}
\hline Sample & $\begin{array}{l}\text { Location } \\
(\mathrm{cm})\end{array}$ & Montm/quartz & $\begin{array}{l}\text { Calcite } \\
(\%)\end{array}$ & $\begin{array}{l}\text { Quartz } \\
(\%)\end{array}$ & $\begin{array}{l}\text { Opal } \\
(\%)\end{array}$ & $\mathrm{SiO}_{2}$ & $\mathrm{Al}_{2} \mathrm{O}_{3}$ & $\mathrm{Fe}_{2} \mathrm{O}_{3}$ & $\mathrm{MgO}$ & $\mathrm{CaO}$ & $\mathrm{K}_{2} \mathrm{O}$ & $\mathrm{Na}_{2} \mathrm{O}$ & $\mathrm{TiO}_{2}$ & $\mathrm{MnO}$ & $\mathrm{H}_{2} \mathrm{O}^{-}$ & $\mathrm{H}_{2} \mathrm{O}^{+}$ & $\begin{array}{l}\text { Grade } \\
\text { no. }\end{array}$ \\
\hline A0 & -5 & & & & & 17.94 & 1.03 & 0.67 & 0.60 & 43.51 & 0.21 & 0.08 & 0.02 & 0.01 & 0.70 & 35.16 & I \\
\hline $\mathrm{A} 1$ & 0 & & & & & 20.65 & 0.77 & 0.74 & 0.55 & 41.50 & 0.43 & 0.02 & 0.02 & 0.02 & 0.77 & 34.20 & II \\
\hline A2 & 5.5 & 2.4 & 4 & 37 & 59 & 71.18 & 7.45 & 4.45 & 1.00 & 2.36 & 0.96 & 0.23 & 0.23 & 0.03 & 5.61 & 5.52 & IV \\
\hline A3 & 14 & 3.5 & 0 & 17 & 83 & 73.44 & 7.15 & 4.17 & 0.92 & 1.64 & 0.89 & 0.16 & 0.16 & 0.01 & 5.76 & 4.78 & IV \\
\hline A4 & 20 & 2.2 & 0 & 31 & 69 & 76.09 & 6.77 & 3.92 & 0.90 & 1.02 & 0.86 & 0.14 & 0.14 & 0.02 & 5.57 & 4.45 & V \\
\hline A5 & 30 & 6.0 & 7 & 75 & 18 & 56.78 & 13.96 & 6.73 & 1.68 & 1.36 & 1.56 & 0.58 & 0.58 & 0.02 & 10.10 & 6.54 & V \\
\hline A6 & 50 & 4.6 & 0 & 31 & 79 & 79.71 & 5.32 & 2.97 & 0.70 & 0.76 & 0.83 & 0.12 & 0.12 & 0.01 & 5.04 & 3.30 & V \\
\hline A6+ & 51 & & & & & 81.08 & 4.94 & 2.58 & 0.60 & 0.72 & 0.85 & 0.15 & 0.15 & 0.01 & 4.57 & 2.98 & V \\
\hline A7 & 72 & 6.3 & 13 & 34 & 53 & 66.41 & 10.79 & 5.36 & 1.23 & 1.35 & 1.38 & 0.41 & 0.41 & 0.02 & 7.45 & 5.34 & V \\
\hline A8 & 82 & 6.4 & 28 & 23 & 49 & 72.97 & 7.95 & 4.50 & 0.90 & 0.98 & 1.04 & 0.32 & 0.32 & 0.03 & 6.48 & 4.69 & V \\
\hline A9 & 106 & 24.5 & 0 & 25 & 75 & 73.61 & 7.76 & 4.49 & 0.90 & 1.03 & 1.02 & 0.11 & 0.28 & 0.03 & 6.14 & 4.40 & V \\
\hline A10 & 130 & 16.6 & 69 & 6 & 25 & 66.42 & 10.43 & 5.79 & 1.14 & 1.42 & 1.45 & 0.14 & 0.39 & 0.07 & 6.77 & 5.66 & V \\
\hline A11 & 163 & 0.0 & 65 & 35 & 0 & 67.12 & 10.00 & 5.42 & 1.10 & 1.42 & 1.47 & 0.15 & 0.42 & 0.08 & 6.07 & 5.47 & V \\
\hline A12 & 203 & 2.8 & 0 & 22 & 78 & 83.80 & 4.45 & 2.58 & 0.50 & 0.82 & 0.71 & 0.10 & 0.11 & 0.03 & 3.81 & 2.91 & V \\
\hline A13 & 211 & 6.0 & 0 & 53 & 47 & 66.35 & 8.75 & 5.25 & 1.20 & 2.68 & 1.61 & 0.12 & 0.28 & 0.03 & 7.20 & 6.16 & IV \\
\hline A14 & 223 & 4.2 & 0 & 37 & 63 & 63.37 & 5.56 & 3.26 & 0.79 & 8.16 & 1.06 & 0.11 & 0.23 & 0.03 & 7.91 & 9.00 & III \\
\hline A15 & 238 & & & & & 22.65 & 1.35 & 1.04 & 0.60 & 39.30 & 0.40 & 0.06 & 0.04 & 0.02 & 1.11 & 32.86 & II \\
\hline
\end{tabular}

calcite veins, bedding planes, cracks, or cleavage from the unweathered limestone and into its weathered counterpart and from there into loose material. The banded sands and silts also incorporate highly angular
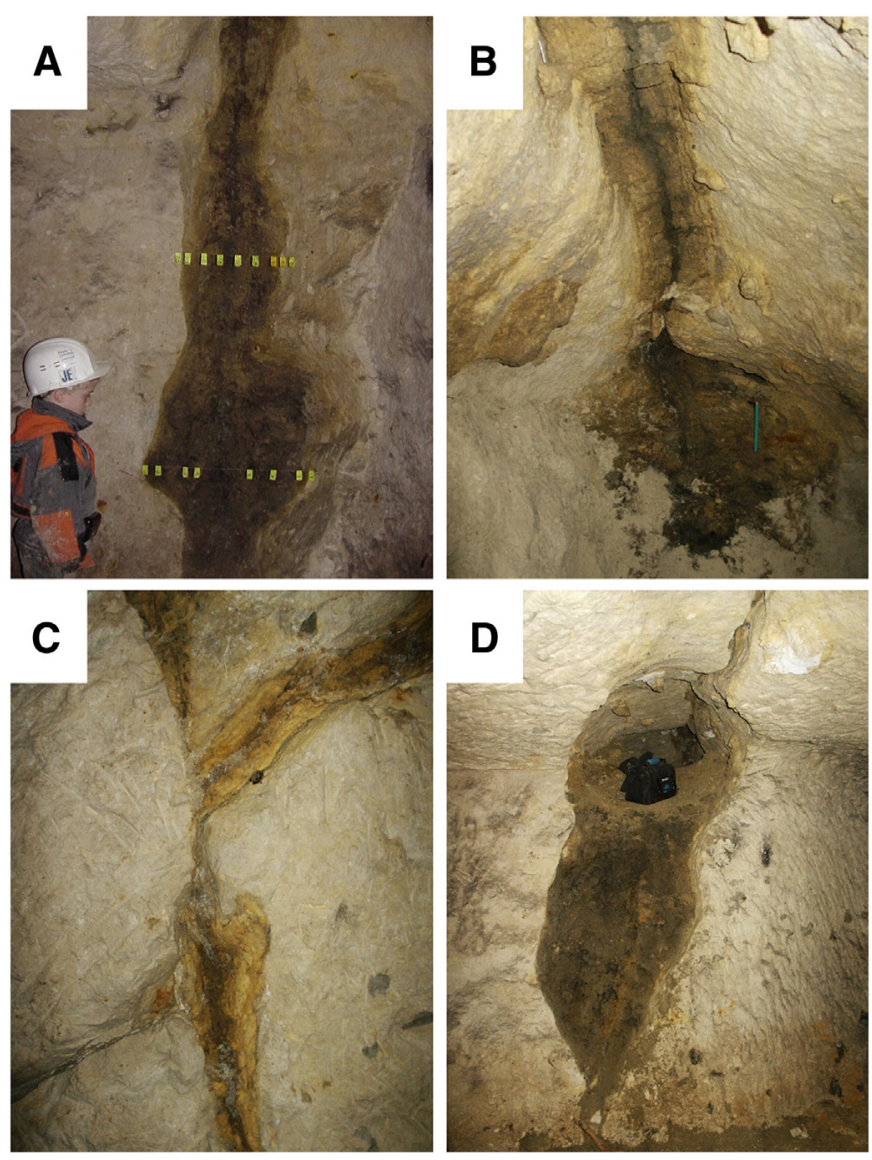

Fig. 44. (A) Section of a weathering feature completely filled by in-situ alterite - the two lines emphasise where samples were taken. (B) Section in an enlarged crack - in the upper part, weathering haloes surround a vein of black smectite whereas, in the lower part, small horizons emphasise the weathering of blocks loosened from the wall. (C) Section of a vault showing two joints abutting against a mini strike-slip - the area weathered within the rock is discontinuous due to infiltration from the surface (scale provided by the little mouse-eared bat). (D) Section of the Gallery of the Banc at La Mansonnière located on oblique cracks - the void at the top of the section formed as a result of compaction of the alterite. "corestones" whose angularity is not indicative of whether or not they are decalcified. Schmidt Hammer Tests have shown that the weathering has caused a loss of compressive strength without necessarily changing in the physical appearance of the limestone. In the main cove of the bay a weathered laminated alterite derived from shale and siltstone has preserved a residual Brigantian conodont assemblage (Błażejowski and Walsh, 2013) and revealed crinoid remains (Rowberry et al., 2014).

The samples subjected to laboratory analyses were obtained from sheltered sites at the base of the cliffs (Rowberry et al., 2014). The analyses comprised calcimetry, granulometry, X-ray diffraction, and exoscopy. The calcimetric analysis provides information regarding the loss of calcium from an impure parent limestone. It has been found that the calcium carbonate content ranges between 3.5\% and 97\% (Fig. 52A and B). There may be an abrupt transition from an unweathered limestone to decalcified clays. The granulometric analysis is able to differentiate between collapse material and isovolumetrically weathered material. It was found that the obtained curves are dominated by fine silt with low or very low quantities of clay and sand - the paucity

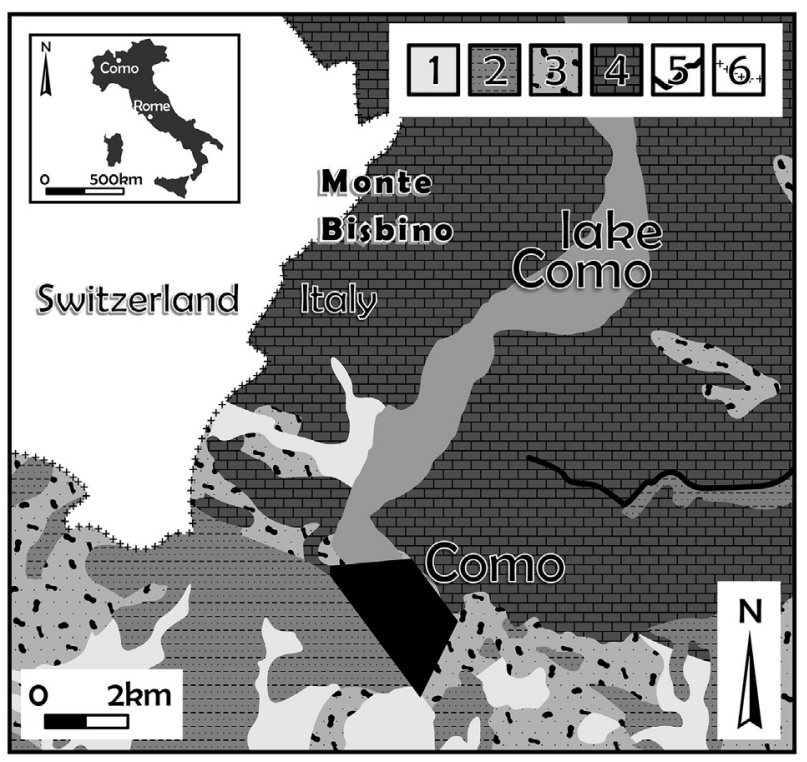

Fig. 45. A geological map of the area around the western part of Lake Como in the Lombardy region of northern Italy: 1 - Quaternary; 2 - Cenozoic (pre-Quaternary); 3 - Cretaceous; 4 - Jurassic; 5 - fault; 6 - national boundary. Monte Bisbino attains an elevation of $1325 \mathrm{~m}$ asl. 
of sand and clay suggests inheritance from the parent rock and reflects in situ weathering process (Fig. 52C and D). The XRD provides information regarding secondary clay formation. The primary minerals in the weathered samples have all been preserved so it is clear that the parent rocks were either impure limestone or shale rich in quartz, illite, and goethite. There is little evidence for secondary clay formation. The exoscopy of individual quartz grains provides information about the initial sedimentary environment and the effects of weathering. The two analysed samples show surface morphologies typical of marine and fluvial grains, respectively, and it has been hypothesised that these morphologies are inherited from transportation prior to diagenesis (Fig. 52E and F) (Rowberry et al., 2014).

\section{Discussion}

The process of karstification by total removal is a single stage process in which chemical dissolution and removal of the soluble species occurs at the same time as mechanical erosion of the undissolved particles. This process is driven by high hydrodynamic energy and creates open voids in the host rock. The process of ghost-rock karstification is, in contrast, a two stage process. The first stage is characterised by chemical dissolution and removal of the soluble species. This stage requires low hydrodynamic energy and creates a ghost-rock feature filled with residual alterite. The second stage, when there is sufficient hydrodynamic conditions are met, is characterised by mechanical erosion of the undissolved particles. It is only during this stage that open voids are created. This two stage model has similarities to the biorhexistasy theory of Erhart (1955, 1967). The first stage of ghost-rock karstification reflects the biostasy stage during which there is weathering of the bedrock under a vegetation cover - after chemical weathering the soluble part of the rock is taken underground while the insoluble part remains to constitute the soils. This situation occurs as the vegetation provides large amounts of acid
A

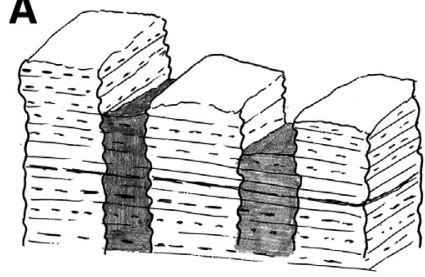

C

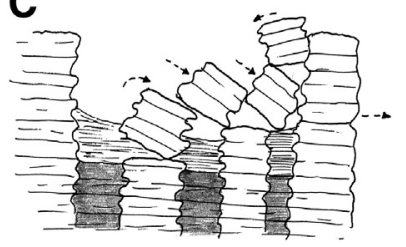

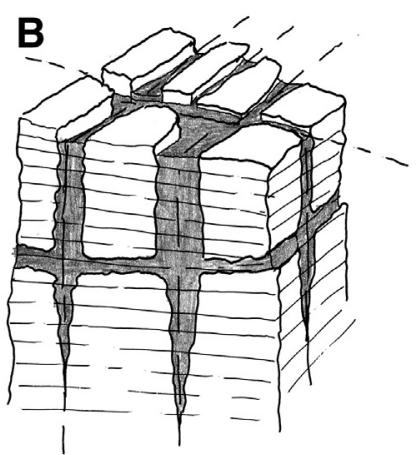

D

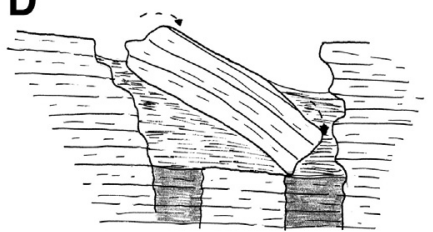

Fig. 47. A series of schematic sketches showing the ghost-rock features on Monte Bisbino: (A-B) an orthogonal network of weathered corridors with constant spacing; (C-D) removal of the residual alterite leads to the formation of rectangular pinnacles and towers that collapse to form screes comprising fresh rock blocks within the residual alterite.

while protecting the residual material from mechanical erosion. The second stage of ghost-rock karstification reflects the rhexistasy stage during which there is mechanical erosion of the residual alterite. Table 2 provides a summary of the presented case studies and highlights the range of lithologies affected by ghost-rock karstification, the timing of the ghostrock weathering, and the subsequent geological history of each region.

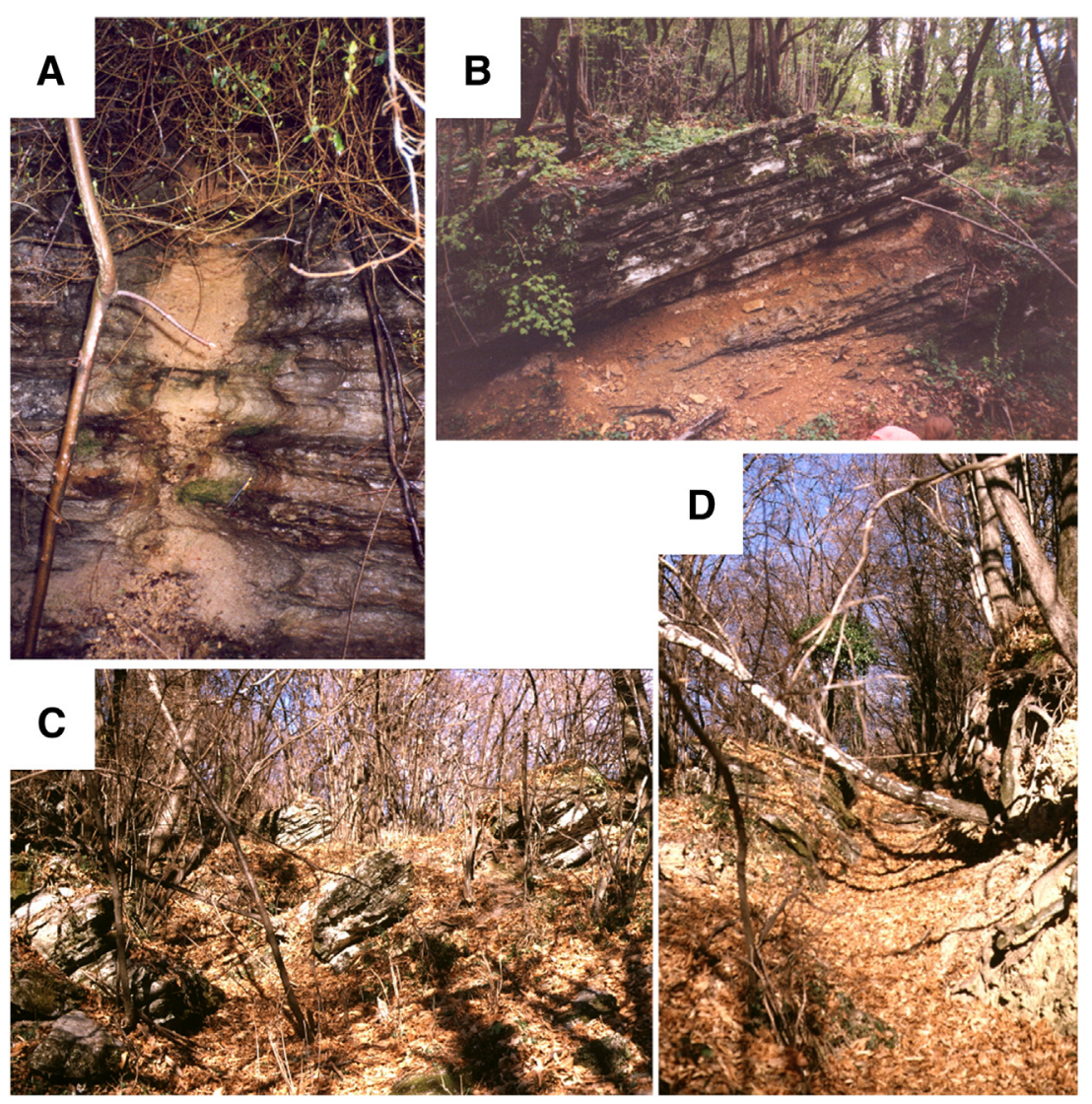

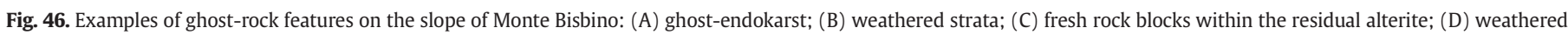
corridor. 


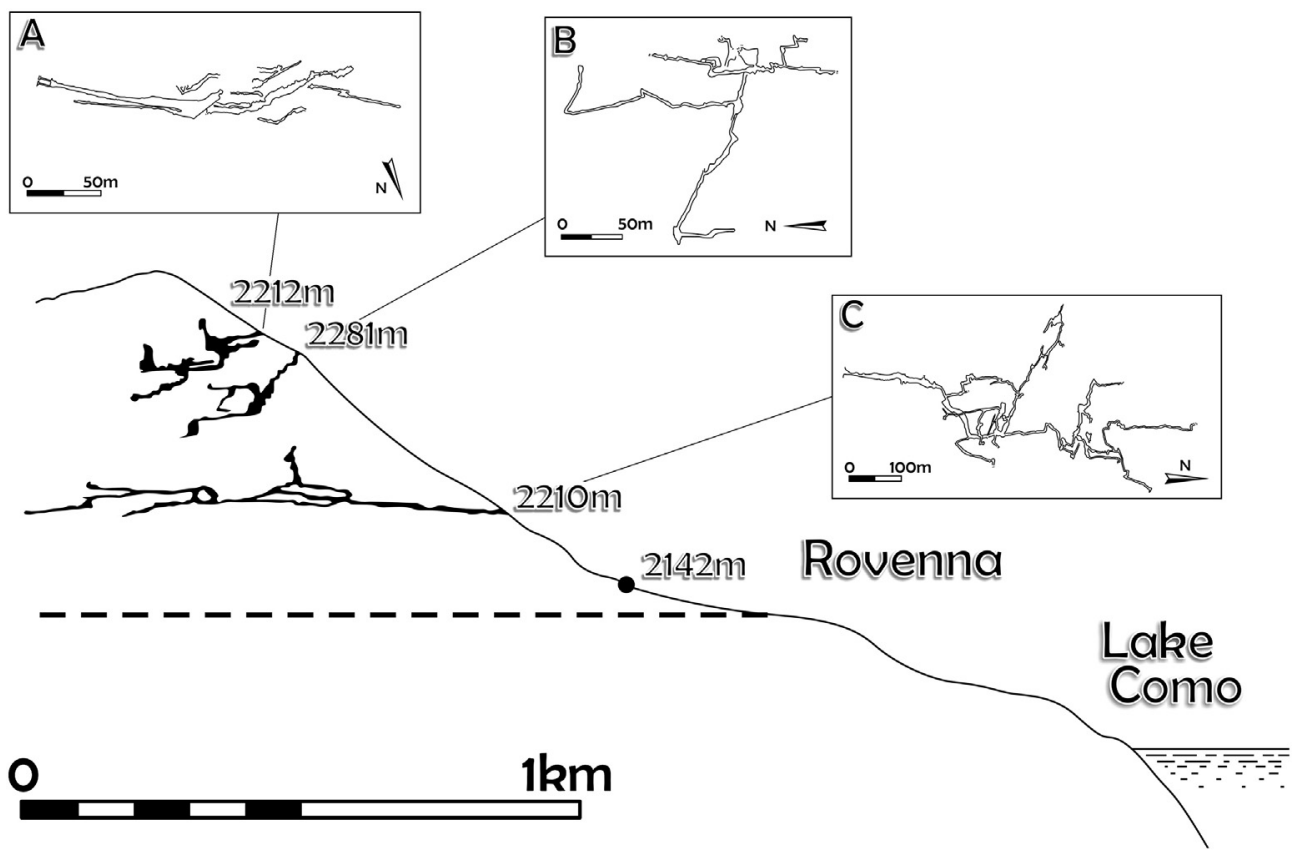

Fig. 48. A cross-section through Monte Bisbino showing the three main cave systems: (A) Zocca d'Ass; (B) Grotta dell'Alpe Madrona; (C) Buco della Volpe. The karst systems have developed above the limit of ghost-rock weathering as depicted by the dotted line.

The 'two-cycle' theory of cave formation proposed by Davis (1930) suggests that most caves develop deep in the phreatic zone and that they are exposed as fully formed features following a cycle of erosion. This hypothesis has been used to account for cave systems with irregular three-dimensional networks and no conspicuous horizontal control. In light of the evidence presented in this review it seems more probable that such systems result from the process of ghost-rock karstification. In geomorphological research there has long been much debate as to whether certain landforms associated with crystalline rocks owe their existence to periods of chemical weathering alternating with periods of mechanical erosion or whether these processes occur simultaneously. The former, for example, has been proposed for the formation of tors in southwest England (Linton, 1955) and inselbergs in Uganda (Ollier, 1960). The latter, for example, has been proposed for the formation of bornhardts in Nigeria (Thomas, 1965). The seminal 'two-stage' model of tor formation first came to prominence following the work of Linton (1955). It was suggested that weathering at the surface proceeded to create a basal platform which then became the ground surface, complete with tors, following removal of the weathered material. Linton (1955) noted that, "This possibility that the weathering implied by the upland tor is late Tertiary is attractive because of the known warmth of our Pliocene climate. To admit such a possibility, however, emphasises the distinction between the two phases of tor formation; exhumation may be much later than decomposition". However, even
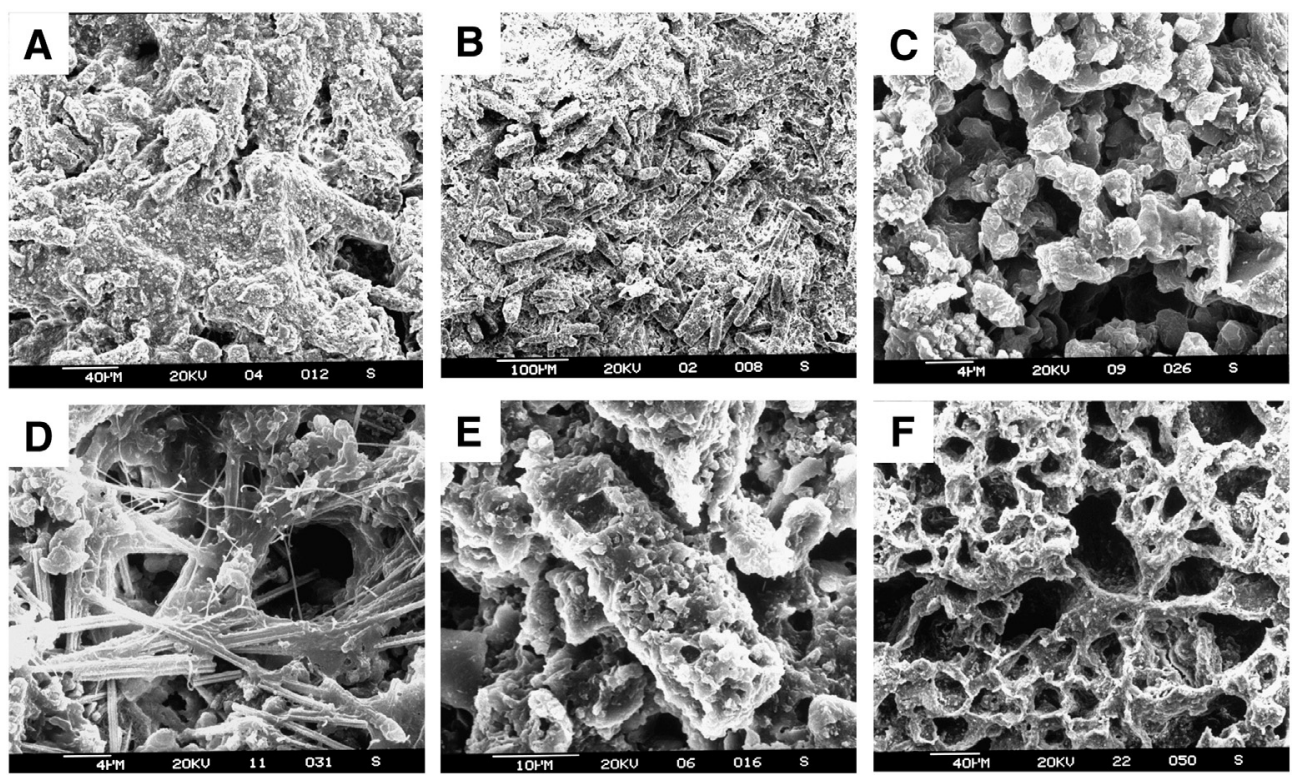

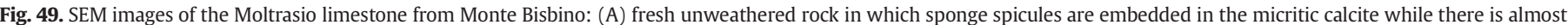

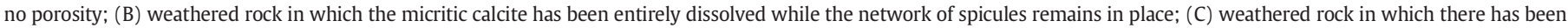

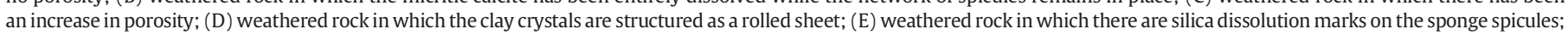
(F) weathered rock in which there are silica dissolution marks on the quartz crystals filling the extension joints. 


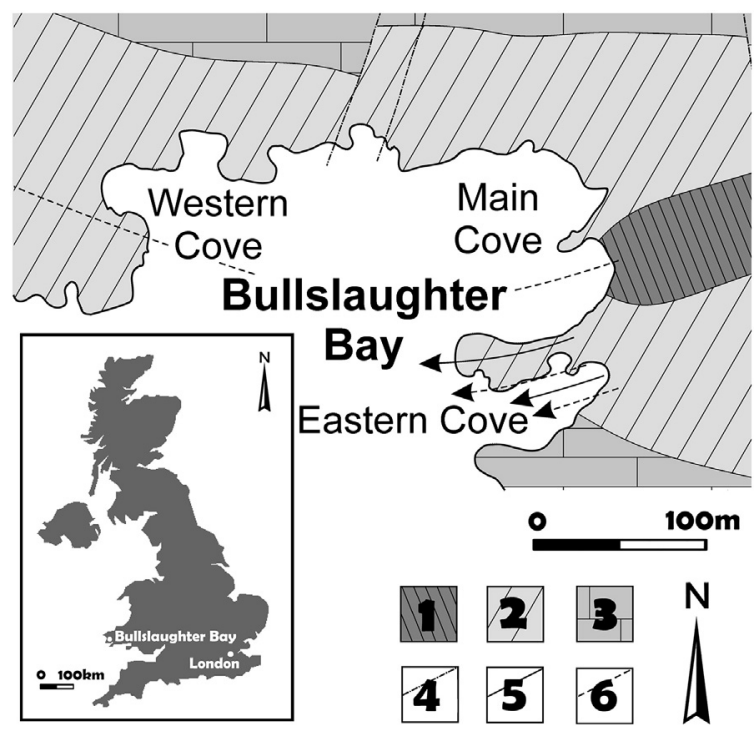

Fig. 50. A simplified geological map of Bullslaughter Bay in southern Pembrokeshire, Great Britain: 1 - Serpukhovian (Pendleian); 2 - Viséan (Brigantian); 3 - Viséan (AsbianBrigantian); 4 - faults; 5 - anticlines; 6 - synclines.

A detailed geological cross-section through the eastern part of the bay was recently presented by Błażejowski and Walsh (2013).

in southwest England, the 'two-stage' model of tor formation is never been unequivocally accepted (e.g. Palmer and Neilson, 1962; Eden and Green, 1971). It is, nonetheless, clear that certain hypotheses used to explain the development of landforms associated with crystalline rocks may have greater applicability in carbonate terrains than has been hitherto appreciated. In this regard it should be unsurprising that certain karst features may owe their existence to periods of chemical weathering alternating with periods of mechanical erosion, as in ghost-rock karstification, or to simultaneous weathering and erosion, rather than in karstification by total removal.

The association between certain karst morphologies and specific karstogenetic processes is often accepted unequivocally. However, if the process of ghost-rock karstification is able to produce caves with the same morphological features to those produced by the process of karstification by total removal, it follows that the processes which are normally assigned to specific cave morphologies may not be constrained accurately (Dubois et al., 2011). It is, for example, commonly accepted that parietal forms within a cave reflect the flow conditions that lead to their formation, such as in the case for both cupolas and vault anastomoses. The hemispherical to ellipsoidal cupola forms often seen in gallery walls and vaults are usually thought to result from chemical corrosion by slowing flowing waters in the flooded phreatic zone. However, these forms have also been found in association with ghost-rock features, at the boundary between the fresh rock and the alterite (Fig. 8A). Likewise, vault anastomoses are generally thought to result from the flow of water in an open channel between the vault and the detritic filling, or in a horizontal joint between the calcareous vault and the clayed interstratum. Again, these forms have also been found in association with ghost-rock features, at the boundary between the fresh rock and the alterite (Fig. 8B). Both the cupolas and vault anastomosis remain after mechanical removal of the alterite and they are very similar to, or possibly indistinguishable from, the same forms that are supposed to have resulted from karstification by total removal. These examples demonstrate that the same karst morphologies may result from different processes - they are examples of geomorphological equifinality. The authors argue that it is no longer acceptable to use karst morphologies in order to infer specific karstogenetic processes.

It has also been shown that cave systems in which the galleries are arranged on different levels do not necessarily reflect changes in base level. Therefore, it may be futile to attempt to link these galleries with, for example, fluvial terraces or glacial stages. However, the process of ghost-rock karstification offers a new explanation for the organisation of such galleries. The weathered network created during the first stage of ghost-rock karstification reflects the fact that the weathering develops along highly transmissive pathways in the host rock - its precise characteristics depend far more on the location of discontinuities such as faults, joints, and bedding planes. Therefore, the weathered network is often characterised by a three-dimensional maze structure which, once emptied of its alterite, creates a cave system with same threedimensional maze structure. This serves to explain how galleries can be arranged on many different levels without needing to invoke base level changes as a cause. It is clear that, over time, one type of
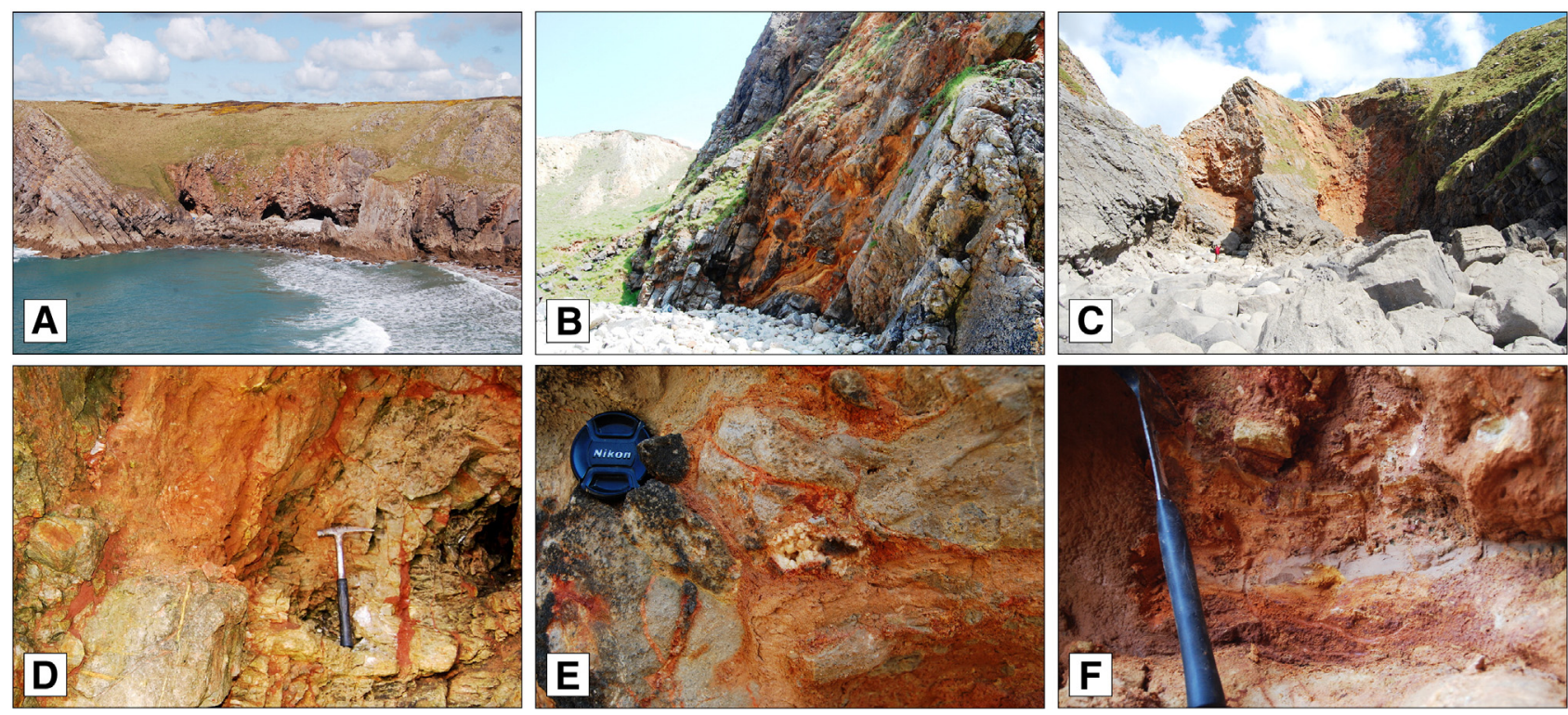

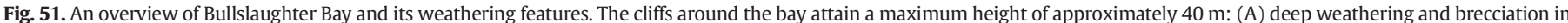

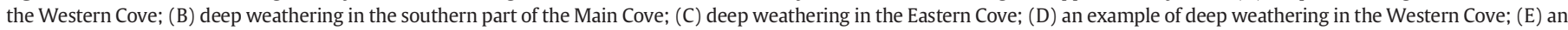

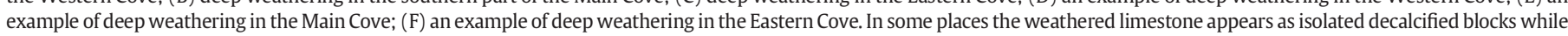
in others it appears as banded ochreous and slightly calcareous sands and silts. 

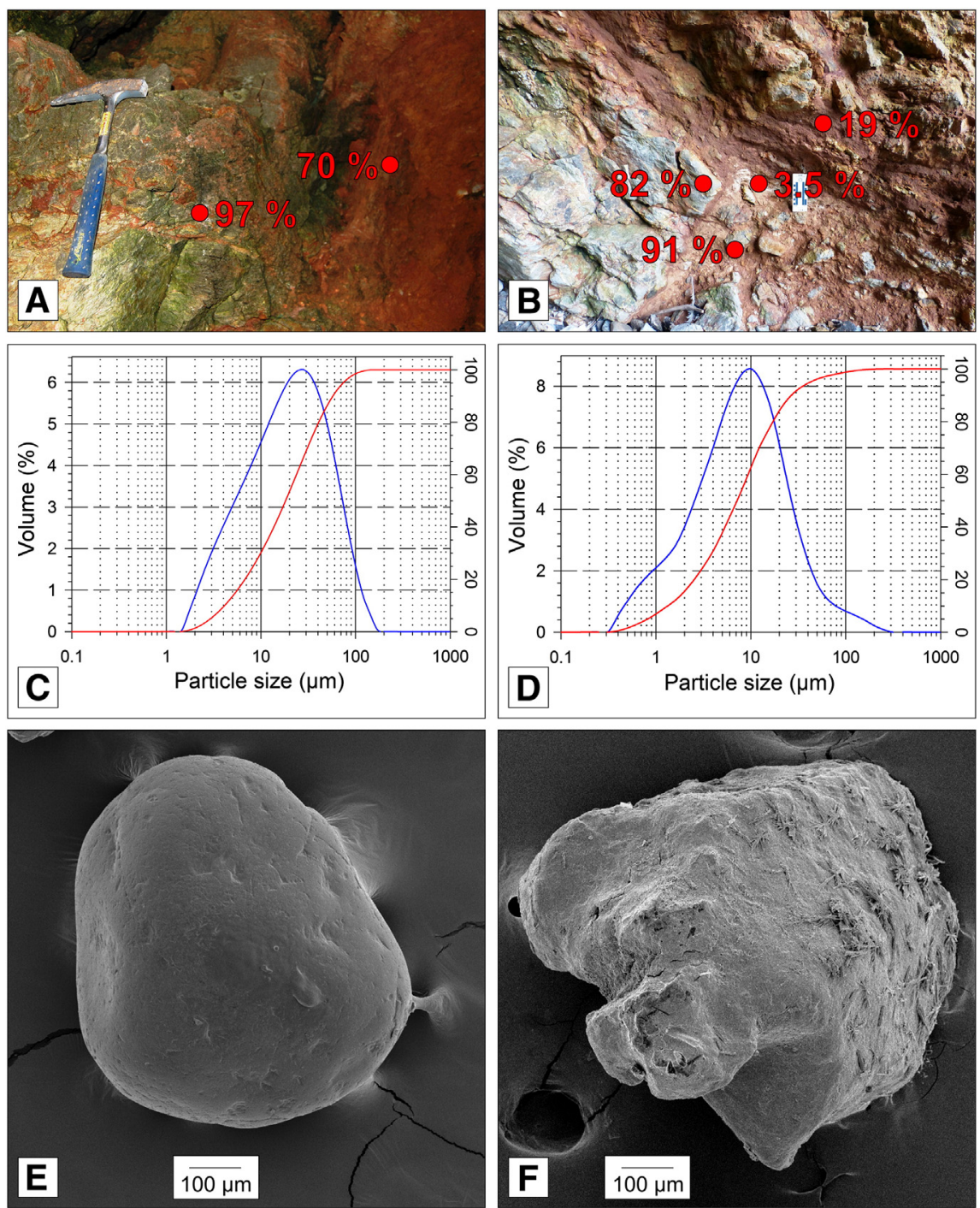

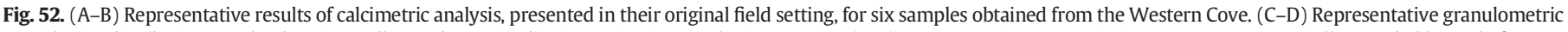

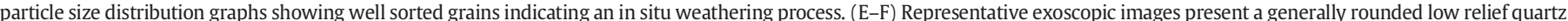
grain (E) and a sub-rounded medium relief quartz grain $(\mathrm{F})$. These morphologies are thought to have been etched prior to diagenesis and rather than reflecting more recent transport

karstification process may supersede the other. Karstification by total removal is perhaps more likely to supplant ghost-rock karstification given that the second stage of the latter process requires mechanical erosion to excavate the alterite. Therefore, if an erosive stream continues to flow after excavation of the alterite, subsequent enlargement of the gallery will reflect the process of karstification by total removal. However, the reverse can also occur if the hydrodynamic energy is lost, and it has been shown that an excavated gallery partly filled with fluvial sediments once again started to develop through ghost-rock karstogenesis.

It is increasingly accepted that karst systems are not solely confined to carbonate rocks and that many such systems are found in siliceous and alumino-siliceous (Galan and Lagarde, 1988; Vicat et al., 2002; Willems et al., 2002a,b; Hardt et al., 2013). These present the same characteristics as karst systems in carbonate rocks (i.e. surface morphologies, underground morphologies, and non-linear hydrodynamics) but they cannot be explained satisfactorily by the traditional single-stage process of karstification by total removal. However, the two stage process of ghost-rock karstification is able to explain the occurrence of karst in supposedly insoluble rocks. During the first stage there is deep chemical weathering of the rock leaving a residual material such as granitic arena - this residual phase incorporates neoformed minerals such as clays which are incompatible with the process of karstification by total removal. During the second stage the mechanical erosion of the alterite excavates galleries, in the case of underground features, or creates karst relief, in the case of surface features (e.g. granitic blockfields).

\section{Conclusions}

This manuscript has reviewed the recently proposed process of ghost-rock karstification. The process integrates chemical weathering and mechanical erosion and fits into the general framework of continental landscape development. The process of ghost-rock karstification differs from the traditional process of karstification by total removal in that it is a two stage process. The first stage is characterised by chemical dissolution and removal of the soluble species to create a ghost-rock feature filled with residual alterite while the second is characterised by mechanical erosion of the undissolved particles to create open galleries. The two karstification processes have been considered from a thermodynamic point of view. Both need a flow of water to provide the chemical energy to dissolve the calcium carbonate. However, karstification by total removal requires a far higher amount of hydrodynamic energy to simultaneously remove the dissolved species and 
Table 2

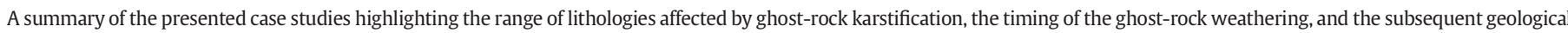
history of each region.

\begin{tabular}{|c|c|c|}
\hline Region and lithology & Initial conditions & $\begin{array}{l}\text { Timing of ghost-rock } \\
\text { karstification }\end{array}$ \\
\hline $\begin{array}{l}\text { Soignies } \\
\text { (Belgium) } \\
\text { Upper Tournaisian } \\
\text { limestone and } \\
\text { dolomitic limestone }\end{array}$ & $\begin{array}{l}\text { Upper Jurassic and Lower } \\
\text { Cretaceous tectonic } \\
\text { extension created open } \\
\text { vertical joints: } \mathrm{N} 60^{\circ} \mathrm{E} \text {; } \\
\mathrm{N} 150^{\circ} \mathrm{E} ; \mathrm{N} 110^{\circ} \mathrm{E}\end{array}$ & $\begin{array}{l}\text { During emergence in the } \\
\text { Upper Jurassic and Lower } \\
\text { Cretaceous }\end{array}$ \\
\hline
\end{tabular}

Tournai
(Belgium)
Upper Tournaisian
siliceous and dolomitic
limestone

$\begin{array}{ll}\text { Engis } & \text { Mesozoic tectonic } \\ (\text { Belgium }) & \text { extension created open } \\ \text { Viséan limestone } & \text { joints }\end{array}$

$\begin{array}{ll}\text { Aquitaine } & \text { Highly porous rock due to } \\ \text { (France) } & \text { weak diagenesis along } \\ \text { Lower Oligocene } & \text { with some vertical tectonic } \\ \text { bioclastic limestone } & \text { joints }\end{array}$

During emergence in the Upper Jurassic and Lower Cretaceous

During emergence prior to Hot and wet climate the Cenomanian accompanied by low relief Cretaceous tectonic extension created open vertical joints: $\mathrm{N} 60^{\circ} \mathrm{E}$; $\mathrm{N} 150^{\circ} \mathrm{E} ; \mathrm{N} 110^{\circ} \mathrm{E}$ joints

Upper Rupelian to Lower Chattian

joints

Hot and wet climate

?At the contact between freshwater and seawater sea-level
Chemical and
hydrodynamic energy

Hot and wet climate accompanied by low relief

a palaeokarst

Danian: a (?tectonic) disturbance generated underground flow during which some weathered features were emptied of their alterite and replaced by a fluvial detrital series. Caves with cupolas were created and then fossilised by transgressions in the Thanetian and Ypresian.

Present: quarrying and pumping has lowered the piezometric level and created new hydrodynamic potential. In the quarries, new caves have formed while, at the surface, alterite compaction has led to the formation of sinkholes.

Cenomanian: marine transgressions during which the karst

became a palaeokarst.

Quaternary: the ghost-palaeokarsts were probably reactivated during glacio-eustatic regression.

Present: quarrying and pumping has lowered the piezometric level and created a new hydrodynamic potential. At the surface, alterite compaction has led to the formation of sinkholes. Neogene: creation of hydrodynamic potential due to uplift. The accompanied by low relief reactivation of some palaeokarsts led to the formation of caves during the Plio-Quaternary. These caves have numerous cupolas and vertical corridors filled with Quaternary sediments while their subsequent development has created galleries with torrential morphologies (e.g. overdeepening, swage, and potholes). Chattian: marine transgressions deposited the 'Agenais Molasses' during which the karst became a palaeokarst. while the area was close to Pliocene-Quaternary: creation of hydrodynamic potential due to uplift and stream incision. The reactivation of some palaeokarsts led to the emptying of horizontal ghost-endokarsts by regressive mechanical erosion.

Present: anthropogenic modification of the vegetation cover has changed the hydrological regime and reactivated the ghostendokarsts.

Burgundy

(France)

Middle Jurassic

limestone

Charente
(France)
Middle and Upper
Jurassic oolitic
limestone

Upper Jurassic to Lower

Cretaceous tectonic extension creates open joints in addition to the bedding planes
During emergence in the Upper Jurassic and Cretaceous

During emergence between the Late Kimmeridgian and the Lower Cenomanian
Hot and wet climate accompanied by low relief

Oligocene: formation of the Bressan Graben and surrounding horst created hydrodynamic potential during which the alterite was partially eroded.

Pliocene-Quaternary: underground rivers flow though the partially emptied ghost-rock features, eroding the remaining alterite, and providing the sedimentary material for the paleontological and prehistoric sites.

Hot and wet climate accompanied by low relief the karst became a palaeokarst close to sea-level

Upper Cretaceous: the creation of sporadic hydrodynamic potential during which sediments became trapped in some partly emptied ghost-rock features and hydraulic breccias formed. Lower Maastrichtian-Danian: continental landscape development with the deposition of sediments from the Massif Central. A sandy-clay Cenozoic overburden covered the landscape and fossilised the ghost-endokarsts.

Pliocene-Quaternary: the creation of hydrodynamic potential due to stream incision resulting from uplift of the Massif Central. The reactivation of some palaeokarsts led to the emptying of deep flooded cavities while water-table fluctuations also helped to empty ghost-rock features and led to the creation of maze caves.

Les Grands Causses

(France)

Jurassic limestone and

dolostone

Normandy (France)

Cenomanian chalk

freestone facies

Lombardy

(Italy)

Liassic silico-clayed

limestone

Pembrokeshire

(Great Britain)

Viséan argillaceous

limestone and mudstone
Greater permeability at the Upper Jurassic to Miocene Hettangian-Sinemurian although ghost-rock contact and tectonic karstification may be onextension between the going in the central parts Cretaceous and the Eocene of the plateaux Erosion of the Eemian impermeable cover during the Quaternary More porous strata and Upper Oligocene with tectonic extension of biostasic conditions subvertical joints ( $\mathrm{N}-\mathrm{S}$ and during the Miocene E-W)

Nearshore or coastal Late Viséan weathering environment with contrasting facies following soon after diagenesis Miocene: the creation of hydrodynamic potential due to stream

Hot and wet climate accompanied by low relief incision resulting from uplift of the Cevennes lead to the onset of erosion of the alterite.

Present: continuing erosion of the alterite which may be enhanced by quarrying.
Wet temperate oceanic climate accompanied by low relief

Hot and wet climate accompanied by moderate relief following the onset of Alpine tectonics Hot and wet climate accompanied by low relief close sea level

Last glacial period: erosion led to the removal of the overlying 'Sands of Perche' which interrupted ghost-rock karstification and fossilised the features.

Upper Miocene: uplift of the Alps interrupted ghost-rock karstification and eroded the alterite.

Messinian: sea-level fall enhanced removal of the alterite from the ghost-rock features by regressive mechanical erosion.

Serpukhovian: deposition of the Pendleian Aberkenfig Formation fossilised the weathered features.

Cenozoic: exhumation reactivated the weathering process. Present: the wide weathered areas are in the process of being removed by the present cycle of marine erosion. 
undissolved particles. The process of ghost-rock karstification has been illustrated by a number of case studies taken from across western Europe. It is suggested that the origins of many karst systems should now be reconsidered in light of this process and that many commonly accepted ideas in karstogenesis must now be revised.

\section{Acknowledgements}

The authors wish to express their gratitude to all the quarrying companies that have granted permission for us to access and work at their sites - so many of the presented case studies would not have been possible without that permission. We would also like to thank Henry Neimark, the General Council of Saône-et-Loire, the members of the Cultural Association of Azé Cave, and Spéléo-Club Argilon for the support they have provided during studies of the karst of Burgundy.

\section{References}

Audra, P., 1994. Karsts Alpins: Genèse de Grands Réseaux Souterrains. Karstol. Mém. 5. Audra, P., Bini, A., Gabrovšek, F., Häuselmann, P., Hobléa, F., Jeannin, P.-Y., Kunaver, J. Monbaron, M., Šušteršič, F., Tognini, P., Trimmel, H., Wildberger, A., 2007. Cave and karst evolution in the Alps and their relation to paleoclimate and paleotopography. Acta Carsol. 36, 53-68.

Ayora, C., Taberner, C., Saaltinka, M.W., Carrera, J., 1998. The genesis of dedolomites: a discussion based on reactive transport modeling. J. Hydrol. 209, 346-365.

Bakalowicz, M., 1975. Géochimie des eaux karstiques et karstification. Ann. Spéliol. 30, 581-589.

Barriquand, J., Barriquand, L., Argant, A., Floss, H., Gallay, A., Guerin, C., Guillot, L., Jeannet, M., Nykiel, C., Quinif, Y., 2011a. Le site des Grottes d'Azé. Quaternaire 4, 15-25 (Special Issue).

Barriquand, J., Barriquand, L., Guillot, L., Nykiel, C., 2011b. Le site des grottes d'Azé. Le fruit de 60 ans de recherches dans le karst du massif de Rochebin (Saône-et-Loire). Spelunca 123, 7-16.

Barriquand, L., Barriquand, J., Baele, J.-M., Dechamps, S., Guillot, L., Maire, R., Nykiel, C. Papier, S., Quinif, Y., 2012. Les grottes d'Azé (Saône-et-Loire, France): de la roche altérée aux sédiments. Karstologia 59, 19-32.

Barusseau, M., 1967. Les Changements de Facies du Jurassique Moyen dans les Monts du MâconnaisLaboratoire de Géologie de l'Ecole Normale Supérieure, Paris (97pp.).

Bates, R.L., Jackson, J.A., 1980. Glossary of GeologySecond ed. American Geological Institute, Falls Church, VA (749 pp.).

Bini, A., 2002. Grotte in Provincia di ComoEdlin, Milan (158 pp.).

Bini, A., Cappa, G., 1977. Some considerations on the applicability of speleogenetic and morphogenetical theories. Proceedings of the 7th International Congress of Speleology, Sheffield, pp. 45-47.

Bini, A., Zuccoli, L., Quinif, Y., 2012. Karst et fantômisation dans la dolomie de la Valle Imagna (Bergamo, Italie). Karstologia 60 (2).

Bisdom, E.B.A., 1967. Micromorphology of a weathered granite near the Ria de Arosa (NW Spain). Leidse. Geol. Meded. 37, 33-67.

Blake, D.F., Peacor, D.R., Allard, L.F., 1984. Ultrastructural and microanalytical results from echinoderm calcite: implications for biomineralization and diagenesis of skeletal material. Micron Microsc. Acta 15, 85-90.

Błażejowski, B., Walsh, P.T., 2013. A Viséan (Brigantian) conodont assemblage preserved in the dissolution residue of a breccia matrix at Bullslaughter Bay, Pembrokeshire, South Wales. N. Jb. Geol. Paläont. (Abh.) 267, 239-254.

Bögli, A., 1964. Corrosion par mélange des eaux. Int. J. Speleol. 1, 11-23.

Bögli, A., 1980. Karst Hydrology and Physical SpeleologySpringer-Verlag, Berlin (284 pp.).

Bonacci, O., 1987. Karst HydrologySpringer-Verlag, Berlin (184 pp.).

Bonnefoy, M., 2002. A 300 pieds sous les Vignes de Rochebin. L'exploration et les travaux d'aménagements des Grottes d'AzéAssociation Culturelle des Grottes d'Azé et Conseil Général de Saône-et-Loire.

Bretz, J.H., 1942. Vadose and phreatic features of limestone caves. J. Geol. 50, 675-811.

Bruxelles, L., 1998. Karsts et paléokarsts du Bassin de Mialet (Bordure Cévenole, Gard): formation et évolution d'un karst démantelé. Karstologia 30, 15-24.

Bruxelles, L., 2001. Dépôts et altérites des plateaux du Larzac central: Causses de l'Hospitalet et de Campestre (Aveyron, Gard, Hérault): evolution morphogénétiques, conséquences géologiques et implications pour l'aménagement. Ph.D. Thesis University of Provence, Aix-en-Provence.

Bruxelles, L., 2002a. Reconstitution morphologique du Causse du Larzac: rôle des formations superficielles dans la morphogenèse karstique. Karstologia 38, 15-28.

Bruxelles, L., 2002b. Ghost structures in the Bajocian limestones of the Causse du Larzac (France). Proceedings of the 1st Geologica Belgica International Meeting, Leuven, pp. 149-152.

Bruxelles, L., Bruxelles, S., 2002. La chasse aux fantômes dans les Grands Causses: utilisation d'un nouveau concept de spéléogenèse dans la recherche de cavités. Spelunca 88, 14-20.

Bruxelles, L., Wienin, M., 2010. Les fantômes de roche de la mine de la Grande Vernissière (Fressac, Gard). Premières observations sur l'origine de certains karsts de la bordure cénévole. Karstol. Mém. 17, 192-200.

Cailhol, D., Meury, P., 2012. Processus de fantômisation dans les calcaires du Jurassique Supérieur du Jura tabulaire. Karstologia 59, 15-28.
Camerman, C., 1947. Le calcaire du Tournaisis. Congrès du centenaire de l'AiLg, section Géologie 349-353.

Caro, P., 1965. La chimie du gaz carbonique et des carbonates, et les phénomènes hydrogéologiques karstiques. Chron. Hydrogeol. 7, 51-77.

Cellule Cartographie/SIG, 2008. Atlas de l'Aquitaine, Les Caractéristiques PhysiquesConseil régional d'Aquitaine.

Courbon, P., Chabert, C., 1986. Atlas des Grandes Cavités MondialesUnion Internationale de Spéléologie, Paris (255 pp.).

Courreges-Blanc, M., Maire, R., 2014. Altération de type fantôme de roche dans les calcaires oligocènes du Médoc (France): étude pétrographique et micromorphologique. Geol. Belg. 17, 9-16.

Dandurand, G., 2011. Cavités et remplissages de la nappe karstique de Charente (bassin de la Touvre, La Rochefoucauld): spéléogenèse par fantômisation, archives pléistocène et holocène, rôle de l'effet de site. Ph.D. Thesis University of Bordeaux.

Dandurand, G., Maire, R., 2011. Essai de typologie des cavités du karst de la Rochefoucauld (Charente): rôle de la "fantômisation» crétacée, du battement de la nappe et de l'effet de site. Dynam. Environ. 27, 11-28.

Dandurand, G., Maire, R., Dubois, C., Quinif, Y., 2014. The Charente karst basin of the Touvre: alteration of the Jurassic series and speleogenesis by ghost-rock process. Geol. Belg. 17, 27-32.

Davis, W.M., 1930. Origin of limestone caverns. Geol. Soc. Am. Bull. 4, 475-628.

Dechamps, S., 2011. Sédimentologie du Bajocien et du Bathonien des grottes d'Azé (France), et comparaison avec le Luxembourg. MSc. Thesis University of Liège.

Delvigne, J.E., 1998. Atlas of micromorphology of mineral alteration and weathering. Canadian Mineralogist Special Publication 3, Ottawa (494 pp.).

Doremus, P., Hennebert, M., 1995. Carte géologique de Wallonie 1:25.000. Planche LensSoignies (Plus Notice Explicative)Ministère de la Région Wallonne.

Dreybrodt, W., 1987. The kinetics of calcite dissolution and its consequence to karst evolution from the initial to the mature state. NSS Bull. 49, 31-49.

Dubois, C., Lans, B., Kaufmann, O., Maire, R., Quinif, Y., 2011. Karstification de type fantômes de roche en Entre-deux-Mers (Gironde, France). Karstologia 57, 19-27.

Dubois, C., Quinif, Y., Baele, J.-M., Dagrain, F., Deceuster, J., Kaufmann, O., 2014. The evolution of the mineralogical and petrophysical properties of a weathered limestone in southern Belgium. Geol. Belg. 17, 1-8.

Dubreuilh, J., 1976. Contribution à l'étude sédimentologique du système fluviatile Dordogne - Garonne dans la région bordelaise. University Thesis Les ressources en matériaux alluvionnaires du département de la GirondeUniversity of Bordeaux 1 .

Eden, M.J., Green, C.P., 1971. Some aspects of granite weathering and tor formation on Dartmoor, England. Geogr. Ann. 53A, 92-98.

Ek, C., 1961. Conduits souterrains en relation avec les terrasses fluviales. Ann. Soc. Geol. Belg. LXXXIV, 313-340.

Erhart, H., 1955. "Biostasie" et "rhexistasie": esquisse d'une théorie sur le rôle de la pédogenèse en tant que phénomène géologique. C. R. Acad. Sci. 241, 1218-1220.

Erhart, H., 1967. La genèse des sols en tant que phénomène géologique. Colloquium on the Evolution of Science, Paris (165 pp.).

Ford, T.D., Cullingford, C.H.D., 1976. The Science of SpeleologyAcademic Press, London (593 pp.).

Ford, D.C., Williams, P., 1989. Karst Hydrogeology and GeomorphologyJohn Wiley \& Sons, Chichester (562 pp.).

Galan, C., Lagarde, J., 1988. Morphologie et évolution des cavernes et formes superficielles dans les quartzites du Roraima (Vénézuela). Karstologia 11-12, 49-60.

Gilli, E., 2011. Karstologie - Karsts, Grottes et SourcesDunod, Paris (244 pp.).

Glansdorff, P., Prigogine, I., 1971. Thermodynamic Theory of Structure, Stability and FluctuationsWiley-Interscience, London (306 pp.).

Grillot, J.C., Guerin, R., 1975. Tectonique, microtectonique et directions des écoulements souterrains: exemples de relations dans le bassin karstique du Haut-Vidourle Gard, France. Rev. Géogr. Phys. Géol. Dynam. XVII, 45-60.

Gründ, A., 1914. Der Geographische Zyklus im Karst. Ges. Erdkunde 52, 621-640.

Guillot, L., Morel, J., Simonnot, G., 2005. Gouffres et cavernes des Monts du Mâconnais. Bulletin des Ligues Spéléologiques de Bourgogne et de Franche-Comté 34-41.

Hardt, R., Rodet, J., Pinto, S.d.A.F., 2013. Complex karst evolution in sandstone: the Chapada dos Guimarães Site, Brazil. Proceedings of the 16th International Congress of Speleology, Brno (Rép. Tchèque). 3, pp. 264-267.

Havron, C., Quinif, Y., Vandycke, S., 2004. Tectonique et karstification: le cas de la région de Han-sur-Lesse (Belgique). Karstologia 43, 19-26.

Havron, C., Baele, J.-M., Quinif, Y., 2007. Pétrographie d'une altérite résiduelle de type "fantôme de roche». Karstologia 49, 25-32.

Hennebert, M., Doremus, P., 1997a. Carte Geologique De Wallonie 1:25.000. Planche Antoing-Leuze (plus notice explicative)Ministère de la Région Wallonne.

Hennebert, M., Doremus, P., 1997b. Carte Geologique De Wallonie 1:25.000. Planche Hertain-Tournai (plus notice explicative)Ministère de la Région Wallonne.

Herak, M., Stringfield, V.T., 1972. Karst, Important Karst Regions of the Northern HemisphereElsevier, Amsterdam (551 pp.).

Jakucs, L., 1977. Morphogenetics of Karst Regions - Variants of Karst EvolutionAdam Hilger Ltd., Bristol (284 pp.).

James, N.P., Choquette, P.W., 2012. PaleokarstSpringer-Verlag, New York (416 pp.).

Jennings, J.N., 1971. KarstMassachusetts Institute of Technology Press, Cambridge MA (252 pp.).

Jolivet, J., Martin, C., 2008. La morphologie karstique dans le canyon de la Cèze et sur le plateau de Méjannes-le-Clap (Garrigues nord, Gard, France) - Rapports avec l'évolution paléogéographique mio-pliocène. Physio-Géo 2, 53-75.

Kaufmann, O., 2000. Les effondrements karstiques du Tournaisis. Genèse, évolution, localisation, prévention. Ph.D. Thesis Faculté Polytechnique de Mons.

Kaufmann, O., Deceuster, J., 2014. Detection and mapping of ghost-rock features in the Tournaisis area through geophysical methods - an overview. Geol. Belg. 17, 17-26. 
Kaufmann, O., Quinif, Y., 1999. Cover-collapse sinkholes in the "Tournaisis” area, southern Belgium. Eng. Geol. 52, 15-22.

Kaufmann, O., Bini, A., Tognini, P., Quinif, Y., 1999. Etude microscopique d'une altérite de type fantôme de roche. Karstologia, Actes du Colloquium, Karst-99.

Klingebiel, A., Gayet, J., Maire, R., 1993. Facteurs faciologiques et tectoniques contrôlant la karstification sur la marge nord-Aquitaine (France): exemple de l'Oligocène nord Aquitaine. C. R. Acad. Sci. II 317, 523-529.

Lans, B., Maire, R., Ortega, R., Deves, G., Bacquart, T., Plaisir, C., Quinif, Y., Perette, Y., 2006 Les stalagmites du réseau du trou Noir (Gironde): rôle de l'effet de site dans l'enregistrement du signal climatique et environnemental. Karstologia 48, 1-22.

Linton, D.L., 1955. The problem of tors. Geogr. J. 121, 470-481.

Lohmann, K.C., 1988. Geochemical patterns of meteoric diagenetic systems and their application to studies of paleokarst. In: James, N.P., Choquette, P.W. (Eds.), Paleokarst. Springer-Verlag, New York, pp. 58-80.

Maire, R., Bruxelles, L., Ortega, R., Roudeau, S., Stratford, D., Braga, J., 2013. Cave genesis in the Cradle of Humankind (South Africa), role of the "ghost-rock» process. Association of Southern African Professional Archaeologists Biennial Conference, Gaborone, 7-13 July 2013.

Mangin, A., 1975. Contribution à l'étude hydrodynamique des aquifères karstiques. Ann. Spéliol. 29 (3), 283-332 (29, 4: 495-601; 30, 1: 21-214).

Mangin, A., 1982. L'approche systémique du karst, conséquences conceptuelles et méthodologiques. Reunion Monografia sobre el Karst, Larra 141-157.

Martel, E.-A., 1894. Les Abîmes: les Eaux Souterraines, les Cavernes, les Sources, la Spéléologie: Explorations Souterraines Effectuées de 1888 à 1893 en France, Belgique, Autriche et GrèceDelagrave, Paris (578 pp.).

Martel, E.-A., 1900. La Spéléologie ou Science des CavernesCarré et Nord, Paris (126 pp.).

Martel, E.-A., 1928. Le Nouveau Traité des Eaux SouterrainesLibrairie Octave Doin Gaston Doin, Paris (838 pp.).

Martini, J., 1985. Caves of South Africa. Karstologia 5, 39-44.

Meunier, A., 1977. Les mécanismes de l'alteration des granites et le rôle des microsystèmes: etudes des arènes du massif granitique de Parthenay (Deux-Sèvres). Ph.D. Thesis University of Poitiers.

Morse, J.W., 1983. The kinetics of calcium carbonate dissolution and precipitation. In: Reeder, R.J. (Ed.), Carbonates: Mineralogy and Chemistry. Mineralogical Society of America, Washington D.C., pp. 227-264.

Nicod, J., 1972. Pays et Paysages du CalcairePresses Universitaires de France, Paris (242 pp.).

Ollier, C.D., 1960. The inselbergs of Uganda. Z. Geomorphol. 4, 43-52.

Palmer, A.N., 1991. Origin and morphology of limestone caves. Geol. Soc. Am. Bull. 103, 1-21.

Palmer, J.A., Neilson, R.A., 1962. The origin of granite tors on Dartmoor, Devonshire. Proc. Yorks. Geol. Soc. 33, 315-339.

Papier, S., Baele, J.-M., Gillan, D., Barriquand, J., Barriquand, L., 2011. Manganese geomicrobiology of the black deposits from the Azé Cave, Saône-et-Loire, France. Quaternaire 4, 297-305 (Special Issue).

Perthuisot, J.-P., 1966. Contribution à l'étude géologique des Monts du Mâconnais (feuilles Tournus $n^{\circ} 5$ et Tournus n ${ }^{\circ} 6$ )Laboratoire de Géologie de l'Ecole Normale Supérieure, Paris (111 pp.)

Price, D.G., 2009. Engineering Geology: Principles and PracticeSpringer, Berlin (472 pp.)

Prigogine, I., 1962. Non-equilibrium Statistical MechanicsInterscience Publishers, New York (319 pp.)

Quesne, D., Guiraud, M., Garcia, J.-P., Thierry, J., Lathuillere, B., Audebert, N., 2000. Marqueurs d'une structuration extensive jurassique en arrière de la marge nordtéthysienne (Monts de Mâconnais, Bourgogne, France). C. R. Acad. Sci. II 330, 623-629.

Quinif, Y., 1989a. Paleokarsts in Belgium. In: Bosák, P., Ford, D.C., Glazek, J., Horacek, I. (Eds.), Paleokarst. Academia, Prague, pp. 35-50.

Quinif, Y., 1989b. La notion d'étages de grottes dans le karst belge. Karstologia 13, 41-49.

Quinif, Y., 1998. Dissipation d'énergie et adaptabilité dans les systèmes karstiques. Karstologia 31, 1-11.

Quinif, Y., 1999. Fantômisation, cryptoaltération et altération sur roche nue, le triptyque de la karstification. Etudes de géographie physique, Travaux 1999 - Supplement 18. University of Provence, pp. 159-164.

Quinif, Y., 2010a. Fantômes de Roche et Fantômisation - Essai sur un Nouveau Paradigme en Karstogenèse. Karstol. Mém. 18.

Quinif, Y., 2010b. Ghost rock structures and the nature of Azé and the Mâconnais. Fieldtrip of the 16th Cave Bear and Lion Symposium. Imprimerie Conseil Général de Saône-et-Loire, pp. 27-39.

Quinif, Y., 2011. Ghost rock structures and the nature of Azé Caves. Quaternaire 4, 7-14 (Special Issue)

Quinif, Y., Maire, R., 2007. La grotte Quentin (Hainaut, Belgique): un modèle d'évolution des fantômes de roche. Colloque International de Karstologie organisé par l'Association Française de Karstologie et ARSIP, Arette, 6-8 September 2007.

Quinif, Y., Maire, R., 2010. La grotte Quentin (Hainaut, Belgique): un modèle d'évolution des fantômes de roche. Karstol. Mém. 17, 214-218.

Quinif, Y., Vergari, A., Doremus, P., Hennebert, M., Charlet, J.-M., 1993. Phénomènes karstiques affectant le calcaire du Hainaut. Soc. Belge Géol. Bull. 102, 379-394.

Quinif, Y., Vandycke, S., Vergari, A., 1997. Chronologie et causalité entre tectonique et karstification. L'exemple des paléokarsts crétacés du Hainaut (Belgique). Bull. Soc. Geol. Fr. 168, 463-472.

Quinif, Y., Meon, H., Yans, J., 2006. Nature and dating of karst filling in the Hainaut Province (Belgium). Karst, geodynamic and paleogeographic implications. Geodin. Acta 19, 73-85.

Quinif, Y., Camelbeeck, T., Delaby, S., Tshibangu, K., Vandycke, S., Van Ruymbeke, M., 2011. Considérations karstogénétiques sur le système de Ramioul. Bull. Soc. R. Belg. Etudes Géol. Archaeol. 3, 79-96 (Les Chercheurs de Wallonie).

Quinif, Y., Baele, J.-M., Deschuyteneer, D., Gline, S., 2012. Fantômisation d'une galerie à remplissage fluviatile (Carrière de Gauthier-Wincqz, Soignies, Belgique). Karstologia $59,15-28$.
Quinif, Y., Baele, J.-M., Dubois, C., Havron, C., Kaufmann, O., Vergari, A., 2014 Fantômisation: un nouveau paradigme entre la théorie des deux phases de Davis et la théorie de la biorhexistasie d'Erhard. Geol. Belg. 17, 66-74.

Rat, P., 2006. Guide Géologique Bourgogne MorvanDunod, Paris (216 pp.).

Renault, P., 1967. Contribution à l'étude des actions mécaniques et sédimentologiques dans la spéléogenèse. Ann. Spéliol. 22, 5-17 (209-267).

Rhoades, R., Sinacori, N.M., 1941. Patterns of groundwater flow and solution. J. Geol. 49, 785-794.

Rodet, J., 1996. Une nouvelle organisation géométrique du drainage karstique des craies: le labyrinthe d'altération, l'exemple de la grotte de la Mansionnière (Bellou-surHuisne, Orne, France). C. R. Acad. Sci. III 322, 1039-1045.

Rodet, J., 1999. Le réseau de fracturation, facteur initial de la karstification des craies dans les collines du Perche: l'exemple du site de la Mansonnière (Bellou-sur-Huisne, Orne France). Geodin. Acta 12, 259-265.

Rodet, J., 2002. Le karst, milieu conservateur. In: Miskovsky, J-C. (Ed.), Géologie de la préhistoire - méthodes, techniques, application. Association pour l'étude de l'environnement géologique de la préhistoire, Paris, pp. 167-187.

Rodet, J., 2003. La Normandie souterraine. In: Guérin, A. (Ed.), La Normandie: la Géologie, les Milieux, la Faune, la Flore, les Hommes. Delachaux et Niestlé, Lausanne, pp. 52-63.

Rodet, J., 2004. Karst and chalk in Normandy: a geographical approach. Proceedings of the 2003 European Meeting of the French Association of Karstology, Rouen, pp. 16-31.

Rodet, J., 2014. The primokarst, former stages of karstification, or how solution caves are born. Geol. Belg. 17, 58-65.

Roques, H., 1967. Chimie des carbonates et hydrogéologie karstique. Mém. Doc. CNRS New Ser. 4, 113-141.

Roques, H., Ek, C., 1973. Etude expérimentale de la dissolution des calcaires par une eau chargée de $\mathrm{CO}_{2}$. Ann. Spéliol. 28, 549-553.

Rowberry, M.D., Battiau-Queney, Y., Walsh, P., Błażejowski, B., Bout-Roumazeilles, V., Trentesaux, A., Kř́ižová, L., Griffiths, H., 2014. The weathered Carboniferous limestone at Bullslaughter Bay, South Wales: the first example of ghost-rock recorded in the British Isles. Geol. Belg. 17, 33-42.

Salomon, J.-N., 2006. Précis de KarstologiePresses Universitaires de Bordeaux, Pessac (288 pp.).

Schmidt, V.A., 1974. The paleohydrology of Laurel Caverns, Pennsylvania. Proceedings of the 4th Conference on Karst Geology and Hydrology, Morgantown, pp. 123-128.

Stainier, M.X., 1899. Carte Géologique de la Belgique (1:40 000). Planche 133 JehayBodegnée-Saint-GeorgesCommission Géologique de Belgique, Institut Cartographique Millitaire.

Swinnerton, A.C., 1932. Origin of limestone caverns. Bull. Geol. Soc. Am. 43, 662-693.

Thomas, M.F., 1965. An approach to some problems of landform analysis in tropical environments. In: Whittow, J.B., Wood, P.D. (Eds.), Essays in Geography for Austin Miller University of Reading, Reading, pp. 118-143.

Thraikill, J., 1968. Chemical and hydrologic factors in the excavation of limestones caves. Geol. Soc. Am. Bull. 79, 17-46.

Tognini, P., 1999a. Individuazione in un nuovo processo speleogenetico: il carsismo del M. Bisbino (Lago di Como). Ph.D. Thesis University of Milan.

Tognini, P., 1999b. The Mt. Bisbino (Northern Italy) karst: a new speleogenetic process Etudes Géog. Phys. XXVIII, 185-190.

Van Den Broeck, E., Martel, E.-A., Rahir, E., 1910. Les Cavernes et les Rivières Souterraines de la Belgique, 2. Lamertin, Brussels.

Vandycke, S., 2002. Paleostress records in Cretaceous formations in NW Europe: extensional and strike-slip events in relationships with Cretaceous-Tertiary inversion tectonics. Tectonophysics 357, 119-136.

Vandycke, S., Bergerat, F., 1989. Analyse microtectonique des déformations cassantes dans le Bassin de Mons. Reconstitution des paléo-champs de contraintes au Crétacé-Tertiaire. Ann. Soc. Geol. Belg. 112, 479-487.

Vergari, A., 1996. Contraintes paléokarstiques dans l'exploitation du calcaire carbonifère sur le bord nord du synclinorium de Namur en Hainaut occidental. Ph.D. Thesis Faculté Polytechnique de Mons.

Vergari, A., 1998. Nouveau regard sur la spéléogenèse: le pseudo-endokarst du Tournaisis (Hainaut, Belgique). Karstologia 31, 12-18.

Vergari, A., Quinif, Y., 1997. Les paléokarsts du Hainaut. Geodin. Acta 10, 175-187.

Vicat, J.-P., Mvondoc, H., Willems, L., Pouclet, A., 2002. Phénomènes karstiques fossiles et actuels au sein des formations métamorphiques silico-alumineuses de la nappe panafricaine de Yaoundé (Sud-Cameroun). C. R. Acad. Sci. II 334, 545-550.

Walsh, P.T., Battiau-Queney, Y., Howells, S.E., Ollier, C.D., Rowberry, M.D., 2008. The Gash Breccias of the Pembrokeshire Peninsula, SW Wales. Geol. Today 24 137-145.

Waters, C.N., Waters, R.A., Barclay, W.J., Davies, J.R., 2009. A lithostratigraphical framework for the Carboniferous successions of southern Britain (onshore). British Geological Survey Research Report RR/09/01.

White, W.B., 1989. Geomorphology and Hydrology of Karst TerrainsOxford University Press, Oxford (464 pp.)

White, W.B., Culver, D.C., 2012. Encyclopedia of CavesElsevier, Amsterdam (654 pp.).

Willems, L., Compère, P., Hatert, F., Pouclet, A., Vicat, J.-P., Ek, C., Boulvain, F., 2002a. Karst in granitic rocks, South Cameroon: cave genesis and silica and taranakite speleothems. Terra Nova 14, 355-362.

Willems, L., Pouclet, A., Vicat, J.-P., 2002b. Existence de karsts en roches cristallines silicatées non carbonatées en Afrique sahélienne et équatoriale, implications hydrogéologiques. Bull. Soc. Geol. Fr. 173, 337-345.

Willems, L., Rodet, J., Fournier, M., Laignel, B., Dusar, M., Lagrou, D., Pouclet, A., Massei, N. Dussart-Baptista, L., Compere, P., Ek, C., 2007. Polyphase karst system in Cretaceous chalk and calcarenite of the Belgian-Dutch border. Z. Geomorphol. 51, 361-376. 